ISSN: 2674-4562; E-ISSN: 2674-4597

DOI: 10.36962/ENECO
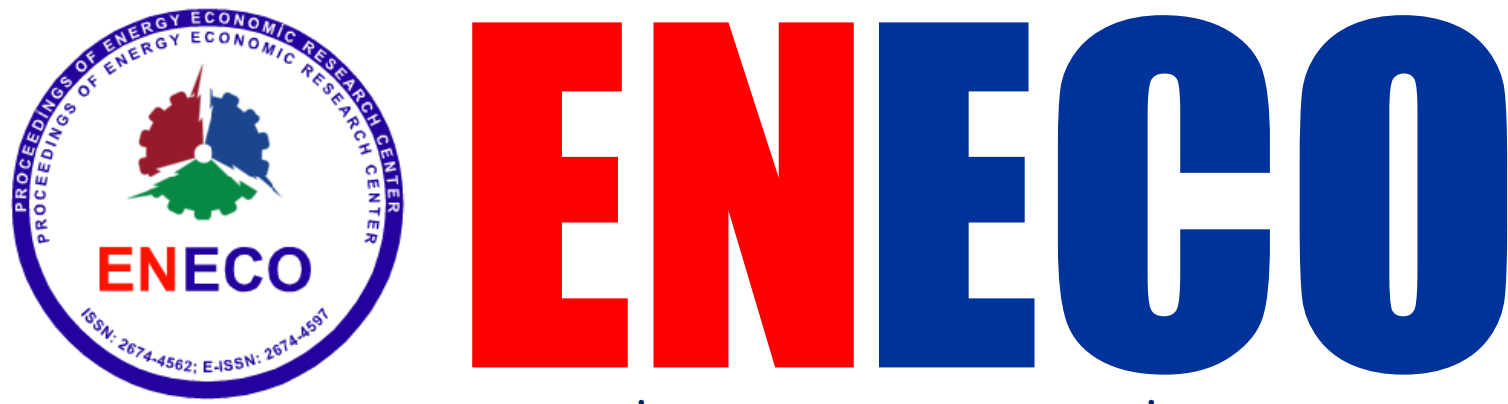

PROCEEDINGS OF ENERGY ECONOMIC RESEARCH CENTER

ENERJİ İQTISADIYYYATI MəRKəZINIIN XəBӘRLӘRİ

VOLUME 06 ISSUE 022021

CILLD 06 BURAXILIŞ 022021

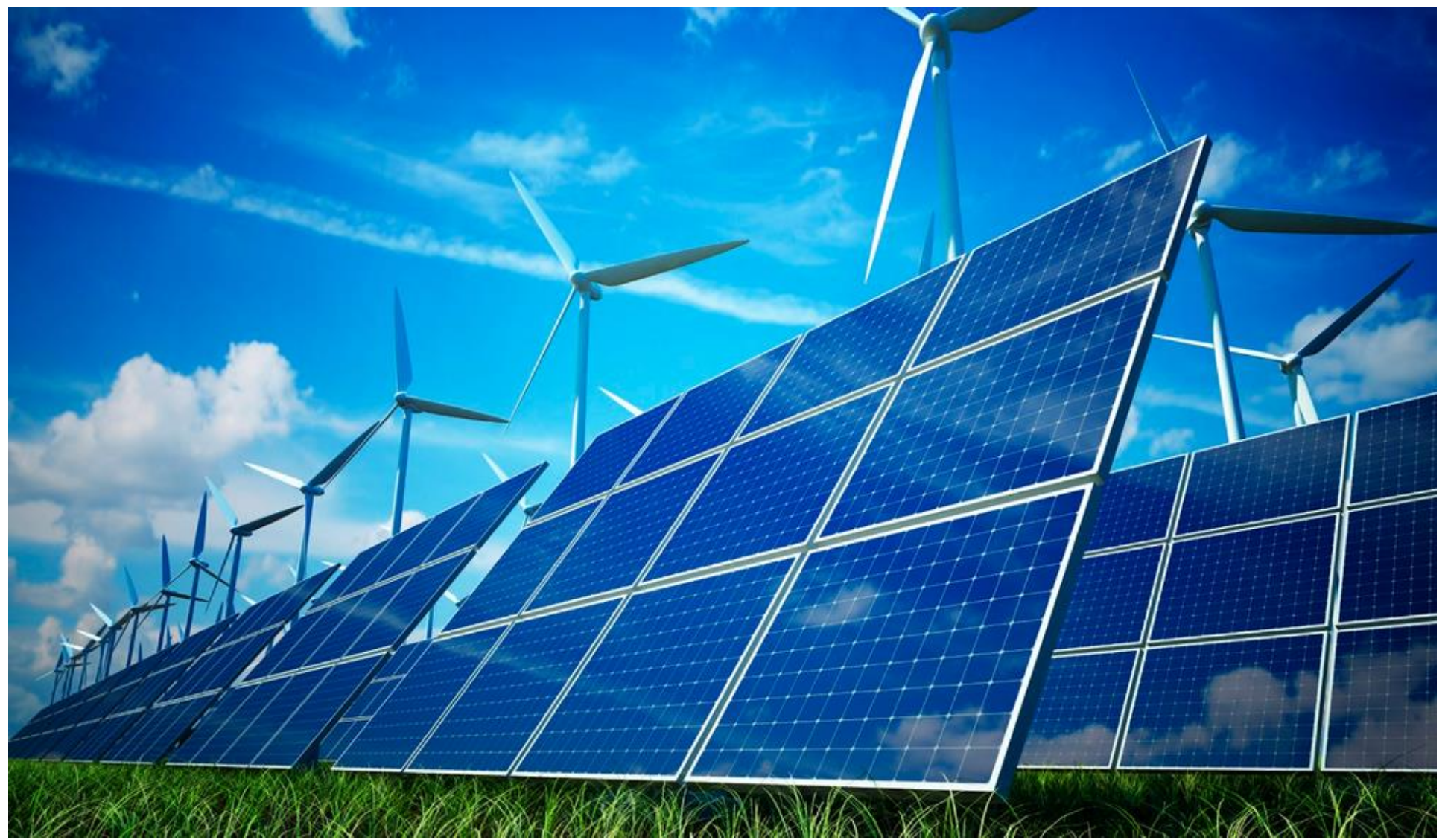

General Economics

International Economics

Business Administration and Business Economics, Marketing, Accounting, Personnel Economics

Economic Development, Innovation, Technological Change and Growth

Agricultural and Natural Resource Economics, Environmental and Ecological Economics

Platform \&

workflow by

OJS/PKP 
The beautiful thing about learning is nobody can take it away from you-B. B. King ISSN: 2674-4562; E-ISSN: 2674-4597 DOI: 10.36962/ENECO
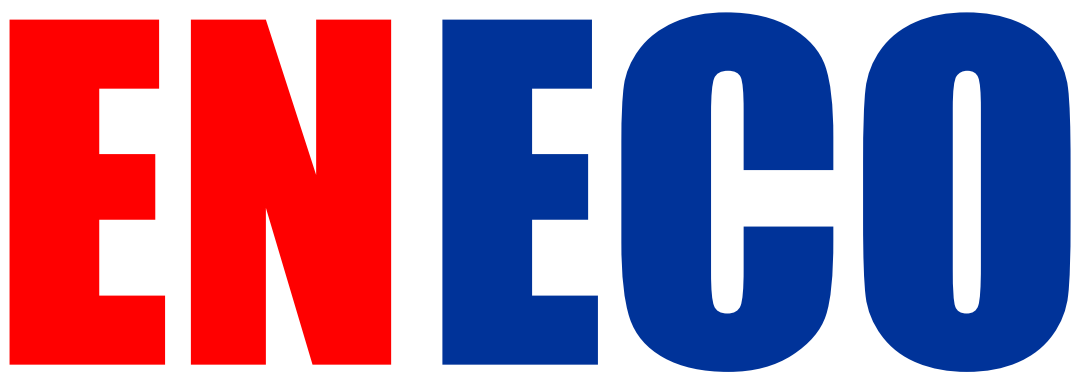

PROCEEDINGS OF ENERGY ECONOMIC RESEARCH CENTER ENERJI İQTISADIYYYTI MəRKəZININ XəBəRLəRI

VOLUME 06 ISSUE 022021

CILD 06 BURAXILIŞ 022021 
Editors-in-chief: Elshan Hajizade

Deputy of Editor-in chief: Namig Isazade

Baş Redaktor: Elşən Hacızadə

Baş redaktorun müavini: Namiq İsazadə

Executive Secretary: Esma İsmayılova

Məsul Katib: Esma İsmayılova

ISSN: 2674-4562, E-ISSN: 2674-4597, UDC: 620.9 (051) (0.034)

OPublisher: 'University of Economics." Energy Economics Center. EEC. (Azerbaijan, Baku)

ONəşriyyat: "'̇qtisad Universitet." Enerji İqtisadiyyatı Mərkəzi. EEC.

Director: Elshan Hajizade. Doctor of Economic Sciences. Professor.

Direktor: Elşən Hacızadə. İqtisad Elmləri Doktoru. Professor.

Deputy of director: Namig Isazade. $\mathrm{PhD}$ in Business Administration.

Direktor müavini: Namiq İsazadə. Biznesin İdarə Olunması üzrə. PhD.

Registered address: 6, Istiglaliet street, Baku, Azerbaijan, AZ 1001

Qeydiyyat ünvanı: 6, İstiqlaliyyət küç. Bakı Azərbaycan, AZ1001

OEditorial office: 6, Istiglaliet street, Baku, Azerbaijan, AZ 1001

ORedaksiya: 6, İstiqlaliyyət küç. Bak1 Azərbaycan, AZ1001

OTypography: ' University of Economics." Energy Economics Center. EEC. (Azerbaijan, Baku)

CMətbəə: '’iqtisad Universitet.'"Enerji İqtisadiyyatı Mərkəzi. EEC. (Azerbaijan, Baku)

Registered address: 6, Istiglaliet street, Baku, Azerbaijan, AZ 1001

Qeydiyyat Ünvanı: 6, İstiqlaliyyət küç. Bakı Azərbaycan, AZ1001

(C) Publisher: MTÜ International Center for Research, Education and Training. (Estonia, Tallinn), R/C: 80550594

CNəşriyyat: MTÜ Beynəlxalq Tədqiqat, Təhsil \& Təlim Mərkəzi. Qeydiyyat kodu: 80550594

Management Board Member: Seyfulla Isayev. Azerbaijan.

Direktor və Təsisçi: Seyfulla İsayev. Azərbaycan.

Deputy \& Founder: Namig Isazade. PhD in Business Administration.

Müavini və Təsisçi: Namig Isazade. $\mathrm{PhD}$ in Business Administration.

CEditorial office / Redaksiya: Harju maakond, Tallinn, Kesklinna linnaosa, Narva mnt 5, 10117

OTypography / Mətbəə: MTÜ International Center for Research, Education and Training. (EESTI, Tallinn),

Registered address / Qeydiyyat Ünvnı: Harju maakond, Tallinn, Kesklinna linnaosa, Narva mnt 5, 10117

Telephones / Telefonlar: +994 5524170 12; +994 518648894

Website/Veb sohifo: https://scia.website/

E-mail: sc.mediagroup2017@gmail.com

Accepted for publication in this edition / Bu nəşrdə dərc oluması üçün qəbul edilib - 04.07.2021
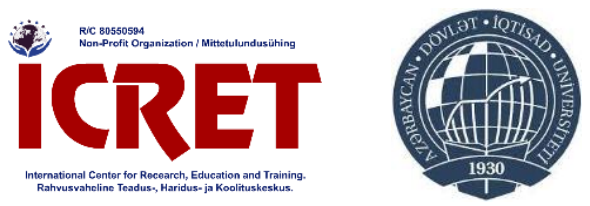

( ) UNEC, MTÜ IRETC. All rights reserved. Reproduction, store in a retrieval system, or transmitted in any form, electronic, mechanic photocopying of any publishing of the journal permitted only with the agreement of the publishers, except in the case of brief quotations embodied in critical reviews and certain other noncommercial uses permitted by copyright law.

The editorial board does not bear any responsibility for the contents of advertisements and papers. The editorial board's views can differ from the author's opinion. The journal published and issued by The Southern Caucasus Media. 
TABLE OF CONTENTS / MÜNDORICAT

\section{Fazil Hajiyev}

ANALYSIS AND EVALUATION OF SUSTAINABLE SOCIO-ECONOMIC DEVELOPMENT OF AZERBAIJAN

\section{Sədaqət İbrahimova, Xaliq Qurbanov}

ALTERNATIV ENERJİ MӘNBӘLӘRINININ İQTISADIYYATIN İNKIŞAFINDA ROLU

Elshan Hajizade

ENERGY SECURITY AND ENERGY EFFICIENCY PRIORITIES IN THE REPUBLIC OF AZERBAIJAN

\section{Gulshan Zeynalova}

CORRELATION OF OIL AND GAS RESOURCES OF THE CASPIAN COUNTRIES 23

\section{Nurlan Hajizade}

THE ROLE AND IMPORTANCE OF TECHNICAL REGULATION IN INCREASING

EFFICIENCY IN THE ENERGY SECTOR

\section{Farhad Babayev}

PROSPECTS FOR THE DEVELOPMENT AND REHABILITATION OF TOURISM IN THE

POST-WAR PERIOD

\section{Gulshan Zeynalova}

FORECAST POTENTIAL OF HYDROCARBON EXPORTS BY THE CASPIAN COUNTRIES AND METHODS OF THEIR TRANSPORTATION

\section{Ayten Mekhraliyeva}

ANALYSIS AND ASSESSMENT OF AZERBAIJAN'S EXPORT POTENTIAL IN THE CONTEXT OF ENTREPRENEURIAL ACTIVITIES 


\title{
ANALYSIS AND EVALUATION OF SUSTAINABLE SOCIO-ECONOMIC DEVELOPMENT OF AZERBAIJAN
}

\author{
Fazil Hajiyev \\ "Accounting and Finance" charter, Ph.D, Azerbaijan State University of Economic (UNEC) \\ Email: fazilhaciyev@yahoo.com
}

\begin{abstract}
One of the global challenges facing the humanity in the 21st century is to improve the sustainable socio-economic development of countries. Thus, significant results have been achieved in Azerbaijan's socio-economic development over the past decade. The main reason for this is the implementation of large economic projects to ensure continued development in Azerbaijan. Innovative development of the economy is associated with the solution of the problem of promotion of innovation, the formation and development of innovative entrepreneurship, fundamental tax reforms and elimination of staff shortages in this area. The most important thing here is that the future state of the Republic of Azerbaijan will find the key government program "Strategic roadmap for key sectors of the national economy".

The socio-economic successes of Azerbaijan in recent years have also been reflected in the reports of reputable international rating agencies. Azerbaijan has been included in the top 20 reformist countries in the World Bank's Doing Business rating. In total, it ranks 34th out of 190 countries. The country is ranked ninth according to the Business Establishment Index. In this report, Azerbaijan entered the top five in the world in terms of starting a business by simplifying business registration and was ranked as one of the best practice countries.[17]

President Ilham Aliyev said at a conference on the results of the first year of implementation of the "State Program on socio-economic development of the regions of the Republic of Azerbaijan for 2019-2023". to raise the level of competitive states. Therefore, given the challenges of the modern world, rapid development in the region will continue.

Taking into account all these pressing scientific issues, the article has become a research problem in the field of industry, agriculture, entrepreneurship and innovation in terms of effective implementation of the strategic roadmap and the importance of sustainable socio-economic development of Azerbaijan in general.
\end{abstract}

Keywords: strategic road map, social-economic development, industry, agrarian area, ownership, innovation.

Introduction: Successful industrialization in the Republic of Azerbaijan requires the strategic roadmap to strengthen the country's industrial potential, modernize its infrastructure, and create and develop industrial parks capable of producing competitive products that meet international standards. At present, the share of industry in the economy exceeds the national average by $30 \%$. According to the United Nations Economic Commission for Europe, Azerbaijan ranks first in Europe for its industry share in GDP. [Hajizada E.M]Accelerating this development A Decree of the President of the Republic of Azerbaijan dated December 6, 2016 approved a strategic roadmap for the development of heavy industry and mechanical engineering in Azerbaijan. It shows that the strategic roadmap for heavy industry and mechanical engineering, including short, medium and long-term periods, is a strategic review and action plan for 2020, a long-term vision for the period until 2025, and a target for the post-2025 period.

The Strategic Roadmap for Industrial and Machine Building states that as a result of the socio-economic policy set out by national leader Heydar Aliyev, the country's economy has grown rapidly over the past decade; diversification of the economy has diminished dependence on the oil factor, and the share of the non-oil sector in economic growth. . The global economic processes since 2008 have further deepened the need to improve the 
competitiveness of local businesses, reduce dependence on imports, and accelerate the dynamic development of the non-oil economy and the efficient use of human capital, the locomotive of an innovative economy. In this regard, as a result of a comprehensive analysis of the priority sectors of the national economy, including international consultants, consistent efforts have been made to apply a sectoral approach and to develop specific proposals for relevant areas.

At a meeting with President Ilham Aliyev on January 13, 2020, he stressed that "Azerbaijan should be the leader of the Fourth Industrial Revolution. Currently, the fourth industrial revolution allows Azerbaijan to change its role in the global revolutionary competition. This will allow us to fully utilize the existing potential of the country's economy and promote innovation. "[17] Thus, 9 enterprises with total investment of $\$ 1.1$ billion were granted resident status at Sumgait Chemical Industrial Park. Of these, the Azertechnolayn plant, which produces steel and polyethylene pipes, mechanical and hydraulic equipment, was launched in 2013. More than half of the plant's output has already been exported. In addition, in 2017, enterprises will produce high-pressure hose and fittings, MST Engineering Services, construction products and additives, Swiss-based chemical company SIKA, a manufacturer of high quality synthetic and semi-synthetic lubricants. Alco Lubricant Company, Agrochemical Azerbaijan, which produces pesticides and agrochemicals, and 3 more polypropylene and high-density polyethylene in 2018, Baku Ferrous Metals and Ferroalloys Company, It produces glass boards based on Float technology [www.azstat.org].

Engine oil processing by 5 residents of Balakhany Industrial Park, PET scrap recycling, printing and printing products using waste paper, production of various products from recycled plastic materials, woodworking 5 an enterprise was established. Residents invested 22.4 million manat into these enterprises. Entrepreneurship has been created to attract new residents to Balakhany Industrial Park [www.azstat.org].

Five enterprises in the industrial zone with total investment of more than 49 million manat - Sun Rise Production, which produces cardboard glasses in the Neftchala Industrial Zone, Togrul-2008, a polyethylene tube manufacturer, Petroqeoaz, a manufacturer of rural disposable installations, Providence Doytch Limited, which manufactures modular school buildings, and Kahf companies producing fish feed, and Azeurocar manufacturing cars. [www.azstat.org].

Work on the establishment of the Masalli Industrial Zone, established by the Decree of the President of the Republic of Azerbaijan on June 13, 2016, is continuing. Entrepreneurs are very interested in the industrial zone. Thus, entrepreneurs have already submitted 33 projects totaling more than 30 million manat. These projects cover mainly furniture production, car repair, aluminum and plastic door windows, and various types of building materials. In addition, a private initiative industrial zone was established in Agstafa. [Hajiyev F.Sh].

Resident of Garadagh Industrial Park - Baku Shipbuilding Plant operates in the construction, repair and maintenance of maritime and engineering activities of various purpose vessels that meet the most modern requirements. In 2016, the plant commissioned Ufug, Zafar and Turan passenger vessels with a capacity of 80 passengers each. To date, the company has built 50-ton towers. The plant also completed the construction of the 6th Generation Semiconductor Pantons and handed over to the customer. The largest current order for the plant is the design and construction of the Khankendi Submarine Building, worth \$ 378 million for BP [Hajiyev F.Sh.].

Cooperation process: In recent years, rapid growth in business and property revenues has been driven by the creation of a business environment and the strengthening of private property, which has led to improvements in the legislative framework, increased government care for various sectors of the economy, improved tax administration, and taxation. the introduction of a modern approach. 
Increasing incomes by a significant percentage increase in inflation has led to an increase in both final consumption and effective savings.

As a result of the dynamic development of the business environment, the country has created favorable conditions not only for local investors, but also for foreign investments. The procedures for starting a business have been substantially simplified, many tax breaks have been identified in the tax legislation, and measures have been implemented to promote entrepreneurship and exports. Private sector, SMEs are not just about improving the business environment and creating new jobs. The development of innovative entrepreneurship, in fact, contributes to sustainable socio-economic development in the country, which is a major radical reform. This reform is being successfully implemented in accordance with the decrees and orders of the President of the Republic of Azerbaijan.

In accordance with the Decree of the President of the Republic of Azerbaijan "On Additional Measures for the Development of Entrepreneurship" dated March 3, 2014, further improvement of business and investment climate, including simplification of procedures, expansion of electronic services, prevention of groundless inspections and other directions. continued. The tasks defined in the Decree require extensive reforms in 8 areas of entrepreneurship [4].

Systematic measures are now being taken to develop the country's entrepreneurship and improve the business environment, and a more progressive regulatory framework is being developed, taking into account international best practices. As a result of reforms in the field of electronic registration of business entities, foreign trade transactions, registration of rights to immovable property, necessary changes were made in the legislation on building permits, improvement of corporate governance, protection of investors' interests and bankruptcy.

At the same time, the Law of the Republic of Azerbaijan "On regulation of inspections in the sphere of entrepreneurship and protection of the interests of entrepreneurs" approved by the relevant Decree of the President of the Republic of Azerbaijan contains many important provisions.

At present, the President of the Republic of Azerbaijan, Mr. Ilham Aliyev, has implemented a number of complex and consecutive measures in recent years in accordance with the strategic line "The future development of our country depends on the development of entrepreneurship", effective government support, tax incentives, subsidies and the efficient distribution of risks. Creating industrial and technology parks and zones, agricultural parks, business incubators, organizing educational events, business forums, exhibitions, etc. As a result of such measures entrepreneurship has become a leading force in the economy. The share of private sector in GDP exceeded $80 \%$ and $75 \%$ in employment. In recent years, President Ilham Aliyev's decrees and orders have improved the business licensing system, prioritizing local businesses in procurement, customs, export and investment promotion mechanisms, with a particular emphasis on business development.

All this allows expanding business activity in the country and, first of all, to increase the gross domestic product. In this regard, it is advisable to pay attention to the output of small businesses by types of economic activity in the country:

Table 1. Share of production of small business by types of economic activity (in percent)

\begin{tabular}{|l|l|l|l|l|l|l|}
\hline № & Name of the fields & 2015 & 2016 & 2017 & 2018 & 2019 \\
\hline 1 & Under the all fields of the economy-total & 8.6 & 9.6 & 10.6 & 10.5 & 10.7 \\
\hline 1.1 & Agriculture, forest and fishing & 1.5 & 1.8 & 4.3 & 4.8 & 5.1 \\
\hline
\end{tabular}


VOLUME 06 ISSUE 022021

\begin{tabular}{|l|l|l|l|l|l|l|}
\hline 1.2. & Industry & 1.4 & 1.2 & 1.6 & 2.2 & 2.4 \\
\hline 1.3 & Construction & & & & & \\
\hline 1.4 & $\begin{array}{l}\text { Repair of retail and wholesale trade machines and } \\
\text { bicycles }\end{array}$ & 57.5 & 53.1 & 49.8 & 46.9 & 47.1 \\
\hline 1.5 & Transport and warehouse & 13.4 & 15.1 & 16.0 & 18.8 & 18.9 \\
\hline 1.6 & Living organization and social housing & 28.2 & 49.4 & 49.9 & 50.3 & 50.8 \\
\hline 1.7 & Information and communication & 1.4 & 4.3 & 5.8 & 7.8 & 8.0 \\
\hline 1.8 & Operations under immovable property & 22.1 & 14.7 & 22.4 & 31.2 & 31.9 \\
\hline 1.9 & Education & 1.7 & 18.6 & 19.5 & 24.7 & 25.1 \\
\hline 2.0 & Rendering health and social services to people & 8.7 & 12.2 & 18.5 & 25.8 & 25.9 \\
\hline 2.1 & Other fields & 50 & 46.9 & 41.6 & 44.9 & 50.1 \\
\hline
\end{tabular}

Source: Statistical indicators of small business in Azerbaijan (2019) Baku, p 21

As can be seen from the table, since 2015, small businesses have been increasing their production volumes dynamically every year. This increase is mainly due to the following sectors: national economy, agriculture, forestry and fishing $-5.1 \%$, industry $-2.4 \%$, wholesale and retail repair of motor vehicles and motorcycles $-47.1 \%$, transport and warehousing - $18.9 \%$, property $-31.9 \%$, education $-25.1 \% .25 .9 \%$ in service provision and $50.1 \%$ in other sectors, the construction sector has not changed in the last two years.

Generally, creating favorable conditions for expanding entrepreneurship in a transparent business and healthy competitive environment is one of the key areas of successful policy for Azerbaijan's dynamic and long-term development. This policy has led to a significant increase in the role of the private sector, including business, in the national economy, as well as in the development of the labor market and job creation in the creation of new jobs.

Conclusion of the analysis: At the conference of the President of the Republic of Azerbaijan on the production and sale of agricultural products in connection with the State program of socio-economic development of the regions of the Republic of Azerbaijan for 2019-2023, one of the tasks is toreate agroparks in the regions. Work on the creation of 51 agroparks and large farms totaling 2.4 billion manat is underway and 45 investment projects totaling 759 million manat have been issued on 23 agro and 20 farms, all of which are the main areas of the agrarian sector. This will contribute to the development of cotton production.

In 1919, productivity was increased as a result of the use of advanced technology in cotton production, one of the most important areas of the agricultural sector. Productivity in cotton fields was 29.5 centners.

As it turns out, with the support of the state, it is possible to achieve any goal that is set when the work is properly organized. As President of the Republic of Azerbaijan Ilham Aliyev noted, "we have almost restored cotton production in Azerbaijan and will continue to develop only in the years to come."[17] 
Cotton development will also give impetus to the development of the light industry, and one of the nine plants in the light industrial park set up in 2016 in Mingachevir is a spinning factory. Supply it with local production will help to increase revenue.

At present, extensive work is being done to revive traditional and export-oriented industries, with regular stimulus measures being taken. One of these areas is also barbarism. Taking into account the favorable conditions for barbarism in our country, the rich experience accumulated in the past, a number of measures are being taken to promote the employment. After a long break, some improvements were made in the production of cocoons. So, our ducks have delivered 22.6 tons of barrels, which is six times more than in 2018. In the production of baramas our miners earned about 204 million manat.

Speaking at the session dedicated to the results of socio-economic development of the Republic of Azerbaijan in 2019 and tasks for the future, President of the Republic of Azerbaijan Ilham Aliyev said: Azerbaijan produces about 5 manat per kilogram of barley delivered to processing facilities in China, with 4.5 million mulberries delivered from the People's Republic of China in 2016-2019 at the expense of state funding to strengthen the new cement production facility. According to the investment program of the year, 200 tons of drying cellars and 120 square meters of drying houses in Zardab, Fuzuli, Barda, Aghsu, Zagatala regions The construction of the wells is nearing completion.

The focus is on the development of inventiveness in traditional agricultural sectors. According to the UN Food and Agriculture Organization, Azerbaijan ranks fourth in the world in terms of hazelnut production. Our country produces about 35 mint nuts a year. In order to accelerate the development of hazelnuts, supply of hazelnut seeds and give it to producers, 700,000 manat was allocated by President Ilham Aliyev's order.

"The goal is to create an additional 40,000 hectares of hazelnuts in a few years starting in 2016, and this process is going to be of great interest to farmers," said the head of state. Here, the state takes on a great role, as all necessary equipment, technical measures and fertilizers are purchased at the expense of the state. The state buys it and gives it to farmers for free.I would like to emphasize once again that the policy shows itself in this direction.We are also expanding the geography of hazelnuts and are currently working in 13 areas.

In general, in 2016, the country brought in the largest foreign exchange nuts: \$ 105 million. At present, there is potential for growing nuts in 46 regions. According to calculations, it is possible to double the production and export of hazelnuts, and easily transfer the currency to 200 million.

Real steps are being taken to establish additional nut trees. In 2016, 16328.5 hectares of hazelnut trees were planted. Of these, 3158 ha belong to Zagatala, 2264.2 ha to Balaken, 2250.2 ha to Gusar, 2037 ha to Khachmaz, 1787.5 ha to Gakh and 1203 ha to Guba.[www.azstat.org]

One of the perpective areas of the agrarian sector is the vineyard. As noted at a meeting of the Cabinet of Ministers, vineyards have developed over the last years at the expense of state support. New gardens are being planted and vineyards are expanding. In this regard, a "State Program on the development of viticulture in the Republic of Azerbaijan for 2012-2020" was adopted to develop viticulture and winemaking under the strategic roadmap. The creation of new vineyards, the expansion of cultivation of table and technical grape varieties, the creation of seed farms and production of basic and auxiliary materials for the vineyards, the provision of vineyard infrastructure, and the maintenance of the vineyard and implementation of activities such as capacity building and so on.In connection with this, in the gardens of 15 hectares of ampelographic collections in Ganja and Absheron, 6 indigenous American varieties are grown, as well as 310 varieties of grapes imported from Azerbaijan and the world. Loss of valuable local grape varieties is prevented. It has been estimated that the number of native grape varieties in the country is usually around 200 or 450, which is generally accepted. In addition, 16 tables and about 20 technical grape hybrids have been created, and new technologies of white and red, as well as Nectar tableware and dark wines have been developed. At the same time, significant resources are allocated by the state for the development of viticulture, the processing industry is preserved, and the number of refrigerators built to keep the grapes supplied is growing. 
All of this necessitates the implementation of a number of new measures in the agricultural sector of Azerbaijan for the effective implementation of the strategic roadmap.

Conclusion: Large-scale reforms in the Republic of Azerbaijan in recent years have had a positive impact on sustainable socio-economic development of the country. As a result, the face of cities and villages of Azerbaijan has changed, and the lifestyle of people has changed. Wide-ranging state programs have been implemented, and socio-economic problems that have been addressed by the people have been addressed. Production and social infrastructure facilities were created, new jobs were created. Azerbaijan's integration into the world economy has accelerated. The Republic has strengthened its leadership positions in the Caucasus and increased its authority in the world community.

Formation and stimulation of sustainable socio-economic development in the country on the basis of deep economic reforms will allow, first of all, to increase gross domestic product and improve the standard of living of the population:

- Improve the normative and legal acts on the regulation of sustainable socio-economic development in the country.

- Efficient use of investment for sustainable social and economic development.

- Accelerate the country's socio-economic development in line with the strategic roadmap objectives.

- Creation of innovative industrial potential for sustainable socio-economic development in the Republic.

- Creating conditions for the formation and development of innovative entrepreneurship in foreign countries.

- Focus on studying the experience of developed countries for sustainable socio-economic development in the regions.

In general, the radical economic reforms in the socio-economic sector under the implementation of the strategic roadmap contribute to the growth of gross domestic product and private sector development. This creates conditions for reducing dependence on imports and expanding non-oil exports.

\section{LITERATURE}

1. Order of President of the Azerbaijan Republic "On strategy roadmap on national economy and main sectors of the economy" dated 16.12.2016.

2. Order of President of the Azerbaijan Republic "On announce of 2014 year as Industry Year" dated 10.01.2014.

3. Order of President of the Azerbaijan Republic "On announce of Agriculture year in the Azerbaijan Republic" dated 12.01.2015

4. Order of President of the Azerbaijan Republic "On announce of Ownership Day in the Azerbaijan Republic" dated 21.04.2016

5. "Azerbaijan 2020: A glance to future" development conception. Baku. 2012, 41 p

6. State program on development of vineyard in the Azerbaijan Republic during 2012-2020 years.

7. Www.azstat.org-State Statistics Committee of the Azerbaijan Republic .Baku.2019.21p

8. Little ownership in the Azerbaijan Republic. Statistic context (2018). Baku "Science" 210 page

9. Ibrahimov I.N (2010) Regulation issues of ownership activity. Textbook (in Azerbaijan language) Baku "Science" 248 page

10. Samadzada Z.A. The main characteristics of economic development model of Azerbaijan in XXI century. Strategic analysis journal. Strategic research center, v 5, 2012, page 9-21. 
11. Abbasov A.B. (1998) Ownership activity: organized types and development problems. Baku "University of Economics" publishing $212 \mathrm{p}$

12. Hajizada E.M (2018). World economy and Azerbaijan textbook (in the Azerbaijan language). Baku "Science" 918 page

13. Hajiyev F.Sh. Analysis of innovated industry potential and audit evaluation. Azerbaijan taxes journal 2016, N1. Page 143-154

14. Hajiyev F.Sh. Role of taxes in stimulation of ownership activity in the Azerbaijan Republic. Azerbaijan taxes journal 2016, N4, pages 71-86

15. http://anfes.gov.az Website of national fund to ownership assistance

16. Kolos A.B. Organization of ownership activity. 2005, page 416

17. "Khalg" newspaper, dated 13.01.2021 


\title{
ALTERNATIV ENERJI MONBӘLORININ İQTISADIYYYATIN INNKISŞAFINDA ROLU
}

\author{
${ }^{1}$ Sədaqət İbrahimova, ${ }^{2}$ Xaliq Qurbanov \\ 1"Menecment" kafedrasının dosenti, i.ü.f.d., ${ }^{2}$ Baş müəllim, \\ ${ }^{1,2}$ Azərbaycan Dövlət Neft və Sənaye Universiteti. \\ Email: ${ }^{1}$ ibrahimovasadagat06@gmail.com, ${ }^{2}$ info.qxm@gmail.com
}

\section{XÜLASə}

Dünya ölkələrinin uzun illər ərzində istifadə etdikləri ənənəvi enerji mənbəyi sayllan karbohidrogen ehtiyatlarının getdikcə tükənməsi dünyada alternativ və bərpa olunan enerji mənbələrindən istifadəni zəruri edir. Günəşdən, küləkdən, bioloji tullantılardan, dənizin dalğalarından alınan və heç bir tullantısı olmayan enerji resurslarından istifadənin üstünlüyü, ekoloji cəhətdən problemin olmaması və təbiəti heç bir zərərli tullantı ilə çirkləndirməməsidir.

Alternativ energetika təkcə ətraf mühitin mühafizəsi üçün vacib deyil. O, ölkələrin, ərazilərin, təsərrüfat sistemlərinin neftdən və onun qiymətindən asılılığını da yumşaldır. Hesablamalara görə, gələcəkdə dünyada alternativ və bərpa olunan enerji mənbələri ETT və yüksək qabaqcıl texnologiyalar sayəsində ənənəvi enerji mənbələrinə nisbətdə ən sürətli inkişaf edən enerji mənbəyi olacaqdır.

Qeyri-ənənəvi enerji mənbələrindən istifadə, iki vacib şərtə əsaslanır: yanacaq mənbəyinin bərpaolunanlığı və verilmiş ərazidə mövcudluğu. Azərbaycan günəşli və küləkli günlərin miqdarına görə tükənməz enerji potensialı baxımından əlverişli imkanlara - bərpa olunan təbii sərvətlərə malikdir. Günəş enerjisindən istifadə sahəsində 3000 Kvt-a qədər gücə malik elektrik stansiyaları qurmaqla ildə 13 min ton şərti yanacağa qənaət etmək, atmosferdə karbon qazını 23 min ton azaltmaq mümkündür. Ölkəmizdə külək enerjisinin illik potensial gücü $800 \mathrm{Mvt,} \mathrm{yəni,} 4 \mathrm{mlrd}$ $\mathrm{kvt/saat} \mathrm{imkanındadır.} \mathrm{Bu} \mathrm{da} \mathrm{ildə} 1$ milyon ton şərti yanacağa, $3.7 \mathrm{mln}$. ton karbon qazına qənaət deməkdir. Bundan əlavə respublika bioqaz, termal sular və dəniz dalğası kimi digər qeyri-ənənəvi enerji ehtiyatlarına da malikdir.

Alternativ enerji mənbələrinin istifadəsi bu potensialın yüksək olduğu və ənənəvi yanacaq resurslarının çatışmadığı rayonlarda daha perspektivlidir. Azərbaycanda bu tip yerlər ucqar dağ kəndləri və dağlıq ərazilər, xüsusi mühafizə olunan təbiət əraziləri ola bilər. Azərbaycanın demək olar ki, bütün əraziləri zəngin alternativ enerji resurslarına malikdir.

Açar sözlər: bərpa olunan enerji, alternativ enerji, hidroenergetika, enerji potensialı, Günəş enerjisi, elektrik stansiyaları, yanacağa qənaət, termal sular, dəniz dalğası, bioqaz.

Alternativ energetika daha çox gələcəyə yönələn perspektiv sahə olaraq, ətraf mühitin təmiz saxlanması və iqtisadi səmərəlilik baxımından əlverişli "yaşıl enerji” kimi - insan varlığı miqyasında tükənməz enerjidir. O təbiətdə hər an təbii olaraq mövcud olan proseslərin insanların ehtiyacları üçün istifadə olunması ilə əldə olunur.

ABOEM-nin inkişafını təmin etmək məqsədilə qoyuluş gücü 2500 meqavat olan elektrik stansiyalarının hesabına ildə 11 milyard kilovat-saat elektrik enerjisi istehsalı nəzərdə tutulmuşdur ki, bu da il ərzində 3 milyard kubmetrə yaxın qaza qənaət etmək deməkdir. Araşdırmalar göstərir ki, ABOEM sahəsinə yatırılan investisiyalar 7-8 il ərzində geri qayıdır.

Alternativ enerji mənbələri arasında su-elektrik stansiyaları da özünəməxsus yer tutur. Su-elektrik stansiyaları hazırda Azərbaycanda istehsal edilən elektrik enerjisinin 12,5 faizini verir. Amma bu 
sahə də geniş imkanlara malikdir. Mütəxəssislərin hesablamalarına görə, ölkədə çaylar üzərində onlarca kiçik su elektrik stansiyaları quraşdırmaqla ildə 3,2 milyard kilovat-saat elektrik enerjisi istehsal etmək mümkündür.

Azərbaycan Respublikasının Energetika Nazirliyi ilə Fransanın "Total Eren”, Norveçin "Equinor", "BP-Azerbaijan", Türkiyə Respublikasının "Tekfen İnşaat", Serbiya, Rumıniya, Bolqarıstan, Sloveniya, Koreya, Avstriya, Almaniya, İsveçrə, Norveç, Gürcüstan və s. onlarla ölkələrin dövlət və şirkətləri arasında alternativ və bərpa olunan enerji sahəsində əməkdaşlığa dair Anlaşma Memorandumu imzalanmışdır ki, bununla da səmərəli fəaliyyətin yüksək səviyyədə təmin olunacağı gözlənilir.

Son dövrlərdə dünya ölkələri özlərinin yanacaq - energetika balansına yeni enerji mənbələrinin cəlb edilməsinə çalışırlar. Dünya ölkələrinin uzun illər ərzində istifadə etdikləri ənənəvi enerji mənbəyi sayılan karbohidrogen ehtiyatları getdikcə tükənməkdədir. Neft-qaz ehtiyatlarının tükənməsi dünyada alternativ və bərpa olunan enerji mənbələrindən istifadə zərurətini yaradır. Buraya müəyyən qurğuların yardımı ilə sudan, küləkdən, günəşdən, bioloji tullantılardan, hətta dənizin dalğalarından alınan, heç bir tullantısı olmayan enerji resursları daxildir. $\mathrm{Bu}$ enerjidən istifadə olunmasının üstünlüyü ondan ibarətdir ki, o, ekoloji cəhətdən heç bir problem yaratmır və təbiəti heç bir zərərli tullantı ilə çirkləndirmir.

Bir tərəfdən, bu enerji mənbələrinin təsərrüfat dövriyyəsinə qatılması üzvi (neft, qaz, torf, daş kömür, odun və s.) yanacaqların istifadəsini azaldır, enerjiyə qənaət edir və ekoloji şəraiti yaxşılaşdırır. Digər tərəfdən də müasir dövrdə dünya ictimaiyyətini narahat edən suallardan biri də budur ki, “bəşəriyyət enerjiyə getdikcə artan tələbatı necə ödəyəcək?”. Hətta enerji böhranı həll edilsə belə, dünya gec-tez bu problemlə, yəni, bərpa olunmayan enerji mənbələri olan neft, qaz, daş kömürün tükənməsi problemi ilə üz-üzə dayanacaqdır. Bu mənbələrdən nə qədər aktiv istifadə ediriksə, onlar bir o qədər azalır və bahalaşır. Hesablamalara görə hələ bu günkü istismar tempi ilə daş kömür 400 - 500, neft və qaz isə maksimum 100 ilə çatacaqdər. Digər tərəfdən isə, Yerin təkinin istismarı və yanacağın yandırılması planeti həddindən artıq çirkləndirir və ekologiyanı getdikcə pisləşdirir. Bəşəriyyət qarşısında ekoloji təmiz, bərpa olunan alternativ enerji mənbələrinin mənimsənilməsi məsələsi getdikcə aktual məsələ olaraq bütün dünya ölkələrini maraqlandırır. Bunların içərisində yalnız günəş və külək enerjisi, bioloji resurslar tükənməz və təbiətə tam təsirsizdir. Alternativ energetika təkcə ətraf mühitin mühafizəsi üçün vacib deyil. O, ölkələrin, ərazilərin, təsərrüfat sistemlərinin neftdən və onun qiymətindən asılılı̆̆ını yumşaldır.

Proqnozlara görə, ümumdünya üzrə enerjiyə olan tələbatın 2040-c1 ilə qədər artacağ1 və 28\%-ə çatacağı gözlənilir. Bu artımın böyük hissəsi isə İqtisadi Oməkdaşlıq və İnkişaf Təşkilatına (OECDOrganization for Economic Co-operation and Development) daxil olmayan və inkişaf etməkdə olan ölkələrin payına düşəcəkdir. Buna səbəb isə həmin ölkələrin iqtisadi səviyyələrinin yüksəlməsi və buna paralel olaraq enerjiyə olan tələbatın da artmasıdır. Xüsusilə də Çin və Hindistan kimi yüksək əhali sayına malik olan ölkələr başda olmaqla, OECD-ə daxil olmayan ölkələrin enerji istehlakı bu təşkilata daxil olan ölkələrin ümumi enerji istehlakını üstələyəcəkdir. Bu fərqin gələcək dövrlərdə daha da dərinləşəcəyi gözlənilir.

Hazırda dünyada elektrik enerjisinin əldə edilməsində alternativ və bərpa olunan enerji mənbələrinə nisbətən ənənəvi enerji mənbələrindən daha geniş istifadə edilir. Belə ki, hazırda ümumdünya üzrə enerji istehlakının $81,7 \%$-i (o, cümlədən 2,2\%-i nüvə enerjisi) ənənəvi enerji mənbələri və $18,3 \%$-i isə alternativ və bərpa olunan enerji mənbələri hesabına təmin edilir.

Hesablamalara görə, gələcəkdə dünyada alternativ və bərpa olunan enerji mənbələri elmi-texniki tərəqqi və yüksək qabaqcıl texnologiyalar sayəsində ənənəvi enerji mənbələrinə nisbətdə ən sürətli inkişaf edən enerji mənbəyi olacaqdır. Lakin bu inkişafa rəğmən, 2040-c1 ilə qədər ənənəvi enerji 
mənbələri hələ də əsas enerji mənbələri olaraq öz yerini qoruyub saxlayacaqdır. Әnənəvi enerji mənbələri 2040-cı ilə qədər ümumi enerji istehlakının 77\%-ni təşkil edəcəkdir. Xüsusilə, təbii qazın ənənəvi enerji mənbələrinin digər növlərinə nisbətdə daha çox inkişaf edən enerji mənbəyi olacağı da gözlənilir. Hesablamalara görə, hazırda ümumi enerji istehlakının 33\%-ni neft və qaz tutduğu halda, 2040-cı ildə bu göstərici cüzi azalaraq 31\% təşkil edəcəyi praqnozlaşdırılır. Bu müddət ərzində isə, nüvə enerjisinə olan tələbatın 1,5 dəfə artması qeyd edilir. Bu göstərici ilə nüvə enerjisi dünyada ikinci ən böyük inkişaf edən enerji mənbəyi olaraq qalacaqdır.

Lakin onu da nəzərə almalıyıq ki, daş kömür, neft və təbii qaz kimi ənənəvi enerji mənbələri tükənən resurslardır. Belə ki, hesablamalara görə bu yanacaqlardan istifadə indiki inkişaf tempi ilə davam edərsə, təxminən neftin 43-50, qazın 65-73, daş kömürün 150-170, boz kömürün isə 500-550 ildən sonra tükənəcəyi proqnozlaşdırılır.

Beləliklə, enerjiyə olan təlabatın ödənilməsində xüsusi çəkiyə malik olan karbohidrogen ehtiyatlarının tükənən olduğunu və artan enerji qiymətlərinin iqtisadiyyata mənfi təsirlərini də nəzərə almaqla, mövcud ehtiyatların gələcək nəsillər üçün qorunub saxlanılmasında, qlobal iqlim dəyişikliklərinin qarşısının alınmasında və dayanıqlı enerji təminatının həyata keçirilməsində alternativ və bərpa olunan enerji mənbələrinin əhəmiyyətini və onlardan istifadənin zəruriliyini daha aydın görmək olar.

Onənəvi enerji mənbələrinin tükənən olması ilə yanaşı, onlardan istifadə zamanı ətraf mühitə qarşı ciddi mənfi təsirləri də qaçılmazdır. Belə ki, bərk və ya maye halında olan yanacaqların yandırılması zamanı Kükürd qazı (SO2), Karbon dioksid (CO2), Azot oksidləri (NOx), Metan (CH4) eləcə də toz, his və s. bu kimi zərərli maddələr əmələ gəlir, bu da ətraf mühitin və atmosferin xeyli çirklənməsinə səbəb olur. Nəticədə atmosferdə "istixana effekti" yaranır. Bu da mümkün iqlim dəyişikliklərinə və qlobal istiləşməyə səbəb olur. Təxmini hesablamalara görə, faydalı qazıntı şəklində çıxarılan enerjidaşıyıcılarının yanmasından hər il atmosferə on milyonlarla ton Karbon qazı (CO2) atılır. Beləliklə, mövcud ənənəvi enerji mənbələrinin tədricən tükənməsi, həmçinin onlardan istifadə zamanı ətraf mühitə vurulan zərərlərin yüksək olması, bu enerji mənbələrinin daha güvənli, tükənməyən və ətraf mühitə qarşı zərərsiz təsirlərə malik alternativ və bərpa olunan enerji mənbələri ilə əvəz edilməsi zəruriyyətini yaradir.

Regionların xüsusiyyətlərindən asılı olaraq alternativ enerjidən istifadənin strukturunda müəyyən mənbələr üstünlük təşkil edir. Məsələn, İslandiya, Danimarka və ABŞ-ın bəzi ştatlarında alternativ enerji istehsalında üstünlük geotermal mənbələrə verilir. Norveçdə daha çox kiçik gücə malik hidroenergetik qurğulardan istifadə edilir. Düzən ərazilərdə külək elektrostansiyalarından, cənub regionlarda günəş batareyalarından istifadə edilir. Zəngin meşə ehtiyatlarına malik ölkələrdə biokütlənin (yonqar, talaşa) yanma texnologiyasından geniş istifadə olunur. Göründüyü kimi qeyriənənəvi enerji mənbələrindən istifadə, iki vacib şərtə əsaslanır: yanacaq mənbəyinin bərpaolunanlığı və verilmiş ərazidə mövcudluğu.

Qeyri-ənənəvi (alternativ) bərpa olunan enerji mənbələri: Biokütlə enerjisi (bioqaz); Külək enerjisi; Günəş enerjisi; Hidroelektrik enerjisi; Geotermal enerjisi; Dalğa enerjisi; Nüvə parçalanmasından yaranan enerji; Termonüvə sintezi enerjisi; Hidrogen yanacağı enerjisi; Qabarma-çəkilmə enerjisi; Dünya okeanının termik enerjisi.

Azərbaycan günəşli və küləkli günlərin miqdarına görə tükənməz enerji potensialı baxımından əlverişli imkanlara - bərpa olunan təbii sərvətlərə malikdir. Günəş enerjisindən istifadə sahəsində $3000 \mathrm{Kvt-a}$ qədər gücə malik elektrik stansiyaları qurmaqla ildə 13 min ton şərti yanacağa qənaət etmək, atmosferdə karbon qazını 23 min ton azaltmaq olar. Ölkəmizdə külək enerjisinin illik potensial gücü $800 \mathrm{Mvt}$, yəni, $4 \mathrm{mlrd} \mathrm{kvt/saat} \mathrm{tərtibindədir.} \mathrm{Bu} \mathrm{da} \mathrm{öz} \mathrm{növbəsində} \mathrm{ildə} 1$ milyon ton şərti yanacağa, $3.7 \mathrm{mln}$. ton karbon qazına qənaət deməkdir. Bundan əlavə respublika bioqaz, termal sular və dəniz dalğası kimi digər qeyri-ənənəvi enerji ehtiyatlarına da malikdir. 
Alternativ enerji mənbələrinin istifadəsi bu potensialın yüksək olduğu və ənənəvi yanacaq resurslarının çatışmadığı rayonlarda daha perspektivlidir. Azərbaycanda bu tip yerlər ucqar dağ kəndləri və dağlıq ərazilər, xüsusi mühafizə olunan təbiət əraziləri ola bilər. Azərbaycanın demək olar ki, bütün əraziləri zəngin alternativ enerji resurslarına malikdir. Ölkəmizin cənub rayonları və Naxçıvan çox yüksək günəş enerjisi resurslarına malikdir. Dəniz neftçıxarma sahələrində, dənizçilikdə, Şirvan Milli Parkı və Ağgöl dövlət təbiət qoruğuna dalğa energetikası effektiv tətbiq oluna bilər. Abşeron-Qobustan ərazisi yüksək külək energetikası potensialına malikdir.

Dünya təcrübəsinə əsaslanaraq, deyə bilərik ki, Tenessi ştatının 4-cü ən böyük şəhəri olan Çattanuqa ABŞ-da ilk dəfə olaraq yalnız günəş enerjisi ilə çalışan hava limanına sahib olub. Layihənin reallaşdırılmasına 7 il vaxt və ABŞ-ın federal mülki aviasiya idarəetməsinin büdcəsindən 5 milyon dollar vəsait sərf edilib. Hava limanı üçün nəzərdə tutulmuş günəş stansiyası 7 il ərzində inşa edilib və onun sahəsi təqribən 2000x1500metr, enerji saxlamas1 və yaratması üzrə ümumi gücü isə 2.64 meqavattdır. Buna görə də, günəş stansiyası hətta buludlu havada və gecələr də hava limanına elektrik enerjisini ötürür. Layihəyə sərf edilmiş 5 milyon dollar investisiya 20 il ərzində öz bəhrəsini verməlidir. Günəş panelləri ilə digər təchizatların çalışma müddəti isə 30-40 il təşkil edir.

Alternativ energetika daha çox gələcəyə yönələn perspektiv sahə olaraq, ətraf mühitin təmiz saxlanması və iqtisadi səmərəlilik baxımından əlverişli "yaşıl enerji” kimi - insan varlığı miqyasında tükənməz enerjidir. $\mathrm{O}$ təbiətdə hər an təbii olaraq mövcud olan proseslərin insanların ehtiyacları üçün istifadə olunması ilə əldə olunur.

1. Küləyin enerjisi. Onun vasitəsi ilə atmosferdəki hava kütlələrinin təbii enerjisi elektrik, mexanik, istilik və s. təsərrüfatda işıınilən enerjilərə çevirilir. Bu da çeşidli mühərriklərlə həyata keçirilir. Böyük külək mühərrikləri ölkələrin ümumi elektrik xəttinə qoşulur, kiçikləri isə ayrı-ayrı bölgələri təmin edir. Külək enerjisi tükənmir, hər yerdə işlənilə bilər və ekoloji cəhətdən təmizdir. Ancaq külək elektrik stansiyalarının qurulması bir sıra texniki və iqtisadi xarakterli çətinliklərlə bağlıdır.

2. Helioenergetika (Günəş energetikası) hər-hansı çeşid enerjinin günəşdən alınmasıdır. Günəş enerji alınması üçün tükənməz mənbədir və ekoloji cəhəttən təmizdir. Onun əsasında qurulmuş energetika perspektivli sahədir. Etimallara görə 2100-cü ildə günəş ən başlıca enerji mənbəyinə çeviriləcəkdir. Bir çox ölkələrdə o, dövlət dəstəyini almış və surətlə inkişaf edir. Bu ölkələrin təcrübəsi göstərir ki, gələcəkdə günəs enerjisi əsasında işləyən güclər ənənəvi energetikanın rəqibi olacaqdır. Yerə düşən günəş enerjisinin miqdarı bütün neft, qaz, kömür və başqa alınmış enerjilərin hamısından dəfələrlə çoxdur. Günəş enerjisinin cəmi 0,0125\%-nin işlənməsi yerdə olan bütün enerji ehtiyaclarını ödəyə bilər. Bu potensial o qədər yüksəkdir ki, hər dəqiqə yerə düşən günəş enerjisi bütün bəşəriyyətin bir illik enerji ehtiyaclarını ödəyə bilər.

3. Alternativ Hidroenergetika. Su enerjisinin təbii yolla istifadəsidir. Bunlar dəniz sularının artmasının, dalğaların enerjisini insan tələbatını ödəyən enerjiyə çevirilməsi yolu ilə alınır. Dəniz sularının artmasından istifadə edən elektrik stansiyaları su elektrik stansiyaların əsas növüdür. Dolayı yolla onlar yerin firlanmasının enerjisini istifadə edirlər. Belə elektrik stansiyalarını dəniz kənarında qururlar, çünki orada günəşin və ayın cazibə gücləri sutkada iki dəfə suyun səviyyəsini dəyişir. Sahildə suyun artması və geri çəkilməsi 18 metrə qədər çata bilər. Enerjinin alınması üçün çay ağızları bəndlə kəsilir, elektrik generatoru və nasos rejimində işləyən su aqreqatları quraşdırılır. Nasos rejimi su artmaları ilə geri çəkilmələri arasında olan zaman işlədilməsi üçün suyu su anbarlarına doldurur. Belə stansiyaları hidroakkumulyasiya elektrik stansiyası adlandırırlar. Okean dalğalarının enerjisi - okean üzərində dalğalarla yayılan enerjidir. Suların şirinləşdirilməsi, elektrik enerjisinin istehsalı, suların anbarlara vurulması kimi faydalı işlərin görülməsi üçün istifadə oluna bilər. Dalğaların enerjisinin mənbəyi küləklərdə və günəşdədir. Bütün okeanların gücündən alınmış 
enerji günəşdən alınandan çox deyil, ancaq dalğa ilə işləyən enerji generatorlarının gücü başqa enerji mühərriklərindən çoxdur.

4. Geotermal energetika yerin dibində olan enerjinin geotermal stansiyaların istifadəsilə elektrik və başqa çeşid enerjilərin alınmasıdır. Vulkanların püskürdüyü yerlərdə dövr edən suyun hərarəti qaynama temperaturundan yüksək olur və yerin üzünə qeyzerlər şəklində çıxır. Yeraltı isti sulara isə xüsusi qurğuların yerin dibinə salınması ilə çatmaq olar. Bu tipli qurğular dünyanın bir çox ölkələrində işləməkdədir.

5. Bioyanacaq - alternativ yanacağın bir növü olaraq, bitki ya da heyvan məhsullarından istehsal edilir. Bioyanacağın daha yayılmış növləri bioetanol, biodizel və bioqazdır. Bioetanol əsasən qarğıdalı və şəkər qamışından düzəldilir. Biodizel bitki yağlarının emal edilməsindən sonra əmələ gələn yanacaqdır. O da bioetanol kimi təmiz halda deyil, dizel yanacağı ilə qarışaraq istifadə edilir. $\mathrm{Bu}$ nisbət fərqli ola bilər, məsələn, B-20 markasının tərkibində $20 \%$ biodizel və $80 \%$ adi dizel vardır. $\mathrm{Bu}$ yanacaqla işləyən avtomobillər üçün özəl mühərrikin quraşdırılmasına ehtiyac yoxdur. Onlar adi dizel yanacağı üçün nəzərdə tutulmuş mühərriklə işləyirlər. Bioetanolun və biodizelin mənfi cəhətləri də vardır: Bioetanolla biodizeli istifadə etməklə avtomobildən ayrilan qazlar ekoloji tələblərə daha uyğun olur, lakin, onların enerji səmərəliliyi adi benzin və dizeldən aşağıdır. Buna görə də mühərrikin gücü azalır və yanacağın işlənməsi artır. Bundan əlavə, bioyanacağın bu çeşidlərindən istifadə edilməsi ərzaq problemi yarada bilər. Çünki kənd təsətüfatı məhsullarından istifado edilir.

Ölkənin təbii potensialından istifadə etməklə alternativ enerji mənbələrinin elektrik və istilik enerjisi istehsalına cəlb edilməsi elektroenergetikanın gələcək inkişaf istiqamətlərində mütərəqqi dəyişikliklər etməyə imkan yaradır. Odur ki, 2004-cü ildə "Azərbaycan Respublikasında alternativ və bərpa olunan enerji mənbələrindən istifadə olunması üzrə Dövlət Proqramı" qəbul edilib. Proqramın əsas vəzifələri elektrik enerjisinin istehsalında alternativ (bərpa olunan) enerji mənbələrinin potensialını müəyyənləşdirmək, bərpa olunan enerji mənbələrini istismara cəlb etməklə, ölkənin enerji resurslarından istifadənin səmərəliliyini yüksəltmək, yeni enerji istehsalı sahələrinin yaradılması hesabına əlavə iş yerlərinin açılmasını təmin etmək, Azərbaycanda ənənəvi enerji mənbələrinin mövcud ümumi gücü nəzərə alınmaqla, alternativ enerji mənbələrinin hesabına enerji gücünün artırılması və bununla da ölkənin enerji təhlükəsizliyinin təminatının yüksəldilməsinə nail olmaqdır. Proqramda Azərbaycanın alternativ (bərpa olunan) enerji potensialı kimi külək, günəş, biokütlə, geotermal (termal sular) enerjisi, kiçik su elektrik stansiyaları göstərilib. Proqramdan irəli gələn vəzifələrlə əlaqədar, demək olar ki, xeyli iş görülüb. İlk növbədə real resurslar, mövcud potensial müəyyənləşdirilmişdir. Aparılan hesablamalara görə, Azərbaycanda tam şəkildə bu enerjidən istifadə etmək üçün real imkanlar yetərincə mövcuddur.

Ölkədə alternativ və bərpa olunan enerji sahəsində idarəetmə sisteminin təkmilləşdirilməsi məqsədilə 2013-cü ildə Azərbaycan Respublikasının Alternativ və Bərpa Olunan Enerji Mənbələri üzrə Dövlət Agentliyi yaradılıb və strateji planı hazırlanıb. Bu planda hədəf-alternativ və bərpa olunan enerji resurslarının istehsalının artırılması və ondan səmərəli istifadə olunmasıdır. Alternativ və bərpa olunan enerji mənbələrinin (ABOEM) tətbiqi istiqamətində müxtəlif layihələr həyata keçirilir və beynəlxalq səviyyədə əməkdaşlıq qurulur. Azərbaycan Respublikası "İqlim Dəyişmələri haqqında" Çərçivə Konvensiyasına əsasən, Təmiz İnkişaf Mexanizmi çərçivəsində Azərbaycan hökumətinin müvafiq sənədlərə qoşulması, ölkənin bir mənbədən enerji asılılığının azaldılması, enerji təhlükəsizliyi və enerji səmərəliliyi məsələlərinin həll edilməsi, vahid enerji siyasətinin hazırlanması və ətraf mühitə vurulan ziyanın aşağı salınması məqsədilə "20-20-20" direktivinə də tərəfdar çıxıb. Həmin direktivin tələblərinə əsasən, 2020-ci ilə qədər Avropa İttifaq1 ölkələrində ABOEM-dən istifadə etməklə enerji istehlakının payının 20 faizə çatdırılması idi. Azərbaycan, Beynəlxalq Bərpa Olunan Enerji Agentliyinə üzv qəbul edilib və beynəlxalq qurumlarla işgüzar əlaqələr qurulub. 
Azərbaycanın hər bir şəhər və rayonunda hibrid tipli elektrik stansiyalarının yaradılması qarşıya məqsəd qoyulmuşdur. Bölgələrdə stansiyaların yaşayış yerlərinə yaxın yaradılması, ilk növbədə, elektrik enerjisi itkisinin qarşısını alır və enerjinin istehlakçıya daha ucuz qiymətə çatdırılmasına imkan verir.

ABOEM-nin inkişafını təmin etmək məqsədilə qoyuluş gücü 2500 meqavat olan elektrik stansiyalarının hesabına ildə 11 milyard kilovat-saat elektrik enerjisi istehsalı nəzərdə tutulmuşdur ki, bu da il ərzində 3 milyard kubmetrə yaxın qaza qənaət etmək deməkdir. Araşdırmalar göstərir ki, ABOEM sahəsinə yatırılan investisiyalar 7-8 il ərzində geri qayıdır.

Azərbaycanda əsas alternativ enerji mənbəyi hesab edilən günəş enerjisindən istifadə sahəsində həyata keçirilən tədbirlər son illərdə geniş formatda öz bəhrəsini verməkdədir. Buna da səbəb Azərbaycanda günəşli günlərin sayının çox olmasıdır. Abşeron yarımadasında və Xəzər dənizinin sahilboyu ərazisində günəş işı̆̆ının müddəti il ərzində 2500, Naxçıvan Muxtar Respublikasında isə 2900 saat təşkil edir. Qobustan Eksperimental Poliqonu və Tədris Mərkəzinin yaradılması bu sahədə atılan uğurlu addımlardandır. Günəş enerjisindən istifadə sahəsində həyata keçirilən tədbirlərdən biri də 2014-cü ildə Agentliyin nəzdində "Azalternativenerji" Məhdud Məsuliyyətli Cəmiyyətinin (MMC) Suraxanı Günəş Elektrik Stansiyasının yaradılması olmşdur. Müasir avadanlıqla təchiz olunan stansiyada elektrik enerjisinin istehlakçıya itkisiz çatdırılması üçün bütün imkanlar yaradılıb. Altı hektar sahədə yaradılan stansiyada 8 min günəş paneli quraşdırılmışdır. Bu panellər gün ərzində təqribən 12 min kilovat-saat elektrik enerjisi istehsal edir. Gələcəkdə burada daha 4 min belə panelin quraşdırılması nəzərdə tutulmuşdur. $\mathrm{Bu}$ isə stansiyanın daha səmərəli fəaliyyət göstərməsi üçün geniş imkanlar açacaqdır.

Alternativ enerji mənbələri arasında su-elektrik stansiyaları da özünəməxsus yer tutur. Su-elektrik stansiyaları hazırda Azərbaycanda istehsal edilən elektrik enerjisinin 12,5 faizini verir. Amma bu sahə də geniş imkanlara malikdir. Mütəxəssislərin hesablamalarına görə, ölkədə çaylar üzərində onlarca kiçik su elektrik stansiyaları quraşdırmaqla ildə 3,2 milyard kilovat-saat elektrik enerjisi istehsal etmək mümkündür.

"Azərbaycan Respublikasında kommunal xidmətlərin inkişafına dair strateji yol xəritəsi"ndə alternativ və bərpa olunan enerji mənbələrinin inkişafı məsələsi öz əksini tapıb. Bu sahədə Azərbaycanda külək və günəş enerjisindən istifadə üçün əlverişli imkanlar olduğundan qarşıdak1 illərdə alternativ enerjidən istifadə daha da genişlənəcəkdir. Ölkənin alternativ və bərpa olunan enerji potensialı 420 meqavat həcmində müəyyən edilir.

Alternativ və bərpa olunan enerji mənbələrindən istifadə, hər bir ölkə üçün dünya üzrə dominant enerji istehsalçılarına olan asılılığın azaldılması və nəticə etibarilə ölkənin enerji təminatında fasiləsizliyin təmin edilməsi mühüm əhəmiyyətə malikdir. Dünya bazarlarında yanacaq məhsullarının qiymətində baş verən hansısa dəyişikliklərdən yaranan risklər minimuma enərək, ölkənin enerji təhlükəsizliyi təmin ediləcəkdir.

Azərbaycan Respublikasının Energetika Nazirliyi ilə Fransanın "Total Eren”, Norveçin "Equinor", "BP-Azerbaijan", Türkiyə Respublikasının "Tekfen İnşaat", Serbiya, Rumıniya, Bolqarıstan, Sloveniya, Koreya, Avstriya, Almaniya, İsveçrə, Norveç, Gürcüstan və s. onlarla ölkələrin dövlət və şirkətləri arasında alternativ və bərpa olunan enerji sahəsində əməkdaşlığa dair Anlaşma Memorandumu imzalanmışdır ki, bununla da səmərəli fəaliyyətin yüksək səviyyədə təmin olunacağı gözlənilir.

Birləşmiş Orəb Omirliklərinin (BӘӘ) "Masdar" və Səudiyyə Orəbistanının “AcwaPower" şirkətləri Azərbaycan ərazisində istehsal edəcəkləri elektrik enerjisinin satış qiymətini hökumət ilə razılaşdırmışlar. Qiymətlər Azərbaycanda elektrik enerjisinin topdansatış qiymətinə (6 qəpik) yaxındır. "AcwaPower"in külək elektrik stansiyasından əldə edəcəyi elektrik enerjisinin hər 
kilovatını 5,5 qəpiyə, “Masdar"1n günəş elektrik stansiyasından əldə etdiyi elektrik enerjisinin isə hər kilovatı 5,7 qəpiyə Azərbaycana satılacaqdır. Hər iki şirkətlə razılaşdırılmış qiymətlərə Đlavə Dəyər Vergisi (ODV) də daxildir. "Masdar" şirkətinin tikəcəyi günəş elektrik stansiyasının qoyuluş gücü 230 MVt, "AcwaPower" şirkətinin tikəcəyi külək elektrik stansiyasının qoyuluş gücü isə 240 MVtdir.

Gürcüstanın elektrik enerjisi təchizatı sisteminin kommersiya operatorunun məlumatına əsasən, onun xaricdən aldığı elektrik enerjisinin 64 faizi Azərbaycanın payına düşüb. Bundan əlavə, Gürcüstan Azərbaycandan Türkiyəyə elektrik enerjisi tranzitini də həyata keçirir.

Dünyada "yaşıl enerji" kimi tanınan bu təcrübə geniş yayılmış və təbii göstəricilərə əsasən Azərbaycanda Bakı şəhəri və Abşeron yarımadasında, işğaldan azad olunmuş ərazilərimizdə külək və günəş enerjisinin böyük potensialı vardır. Azərbaycanın dilbər guşəsi Qarabağda "yaşıl enerji” layihələrinin geniş miqyasda tətbiq edilməsi və ərazinin yaşıl zonaya çevrilməsi zamanın əsas tələbi olaraq, hədəf seçilib. Ölkə başçısı "Yaşı1 enerji” konsepsiyasının Azərbaycan üçün nə qədər önəmli olduğunu qeyd edib: "Bu, bütün ölkəyə və xüsusən də azad olunmuş ərazilərə aiddir. Azad olunmuş bütün ərazilər "yaşıl enerji zonası"nı təşkil edəcəkdir. Eyni zamanda orada "ağıllı şəhər” və "ağıllı kənd" adlanan müasir texnologiyalar tətbiq ediləcəkdir. Bu da Azərbaycanın yenidənqurma, müasirləşmə və texnoloji tərəqqiyə ehtiyac olduğu digər bölgələr üçün nümunə olacaqdır”. Hazırda "yaşıl enerji”" texnologiyası dünyada çox sürətlə inkişaf edir və güman ki, gələcəkdə onlar asanlıqla atom elektrik stansiyalarını əvəz edəcəkdir.

AES-lərdən gələn təhlükənin kifayət qədər böyük olmasına baxmayaraq, onların sayı ildən-ilə artmaqda davam edir. Məhz AES-lərin işə düşməsindən sonra ETT-yə nail olunmuşdur. Xüsusilə də kosmosun fəthinə geniş perspektivlər açılmışdır. Sivil dünyanı AES-siz təsəvvür etmək mümkün deyil. Dünyada tez-tez müzakirə edilən məsələlərdən biri atom energetikasıdır. Lakin təhlükələri nəzərə alaraq, artıq dünya dövlətləri, xüsusilə də nüvə stansiyalarının daha çox cəmləşdiyi Avropa məkanı ənənəvi enerji istehsalına və karbohidrogen ehtiyatların idxalı prosesinə üstünlük verməyə başlayıb. Külək, günəş, geotermal, eləcə də neft-qaz enerjisi istehsalını artıran dövlətlər nüvə enerjisindən imtina etməyə hazırlaşırlar. İndi dünyanın ən qabaqcıl texnologiyaları alternativ enerjidən istifadənin stimullaşdırılmasına və ekoloji tarazlığın təmin edilməsinə yönəlib.

2019-cu ildə Azərbaycanın enerji balansı haqqında statistik məlumatlara əsasən, ölkədə ümumi istehsal həcmi 70,5 milyon neft ekvivalenti tonu olan enerji məhsullarının 87,6 faizini ilkin enerji məhsulları, 8,7 faizini neft məhsulları, 3,7 faizini istilik və elektrik enerjisi təşkil etmişdir. Bütün ilkin enerji məhsullarının 62,5 faizini xam neft (qaz kondensatı da daxil olmaqla), 37,1 faizini təbii qaz, 0,4 faizini isə bərpa olunan enerji mənbələri üzrə istehsal olunmuş enerji məhsulları təşkil etmişdir. Azərbaycan xam neft, təbii qaz və neft məhsulları ixrac edən ölkədir. 2019-cu ildə ölkədə ixracın həcmi 44,5 milyon neft ekvivalenti tonu təşkil etmiş, bunun 72,3 faizi xam neftin, 24,8 faizi təbii qazın, 2,6 faizi neft məhsullarının, 0,3 faizi isə elektrik enerjisinin payına düşmüşdür. 2018-ci illə müqayisədə ümumi enerji təchizatı 9,6 faiz artmış və 17,0 milyon neft ekvivalenti tonu təşkil etmişdir. Ümumi enerji təchizatının 21,3 faizini transformasiya sektorunun prosesləri, 5,4 faizini itkilər, 6,6 faizini energetika sektorunun daxili istehlakı, 66,7 faizini son istehlak və s. təşkil etmişdir. Enerji məqsədli son istehlakın 38,0 faizi ev təsərrüfatlarının, 16,3 faizi sənaye və tikintinin, 28,0 faizi nəqliyyatın, 17,7 faizi isə iqtisadiyyatın digər sahələrinin payına düşmüşdür 
Bərpa olunan enerji mənbələrindən alınan elektrik enerjisinin ümumi elektrik enerjisi istehsalında xüsusi çəkisi, faizlə

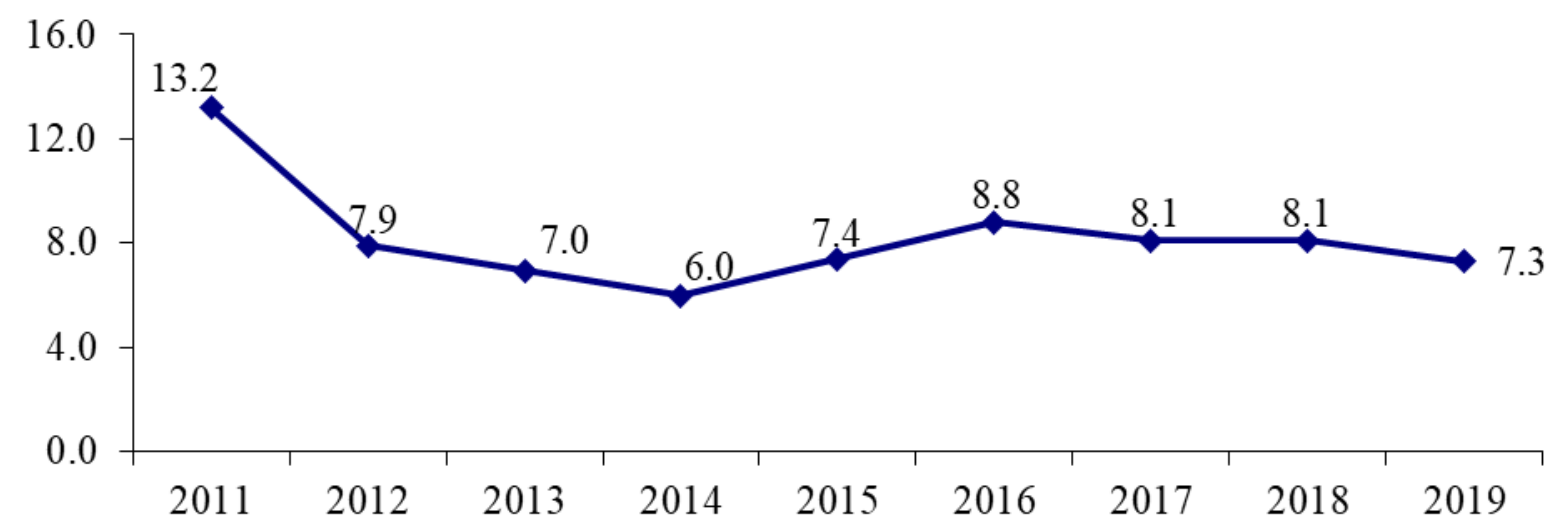

Şəkil 1. Mənbə Azərbaycan Dövlət Statistika Komitəsi.

\title{
ӘDӘВIYYAT
}

1. S.V.İbrahimova "Qeyri-neft sənayesinin iqtisadiyyatı”, dərslik, Bakı 2020.

2. htts://minenergy.gov.az

3. htts://www.e-qanun.az

4. htts://president.az

5. htts://eco.gov.az

6. stat.gov.az

\section{THE ROLE OF ALTERNATIVE ENERGY SOURCES IN ECONOMIC DEVELOPMENT}

\author{
${ }^{1}$ Sedaget Ibrahimova, ${ }^{2}$ Khalig Gurbanov

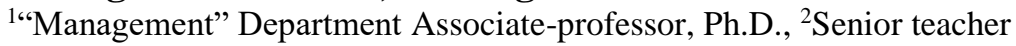 \\ ${ }^{1,2}$ Azerbaijan State Oil and Industry University.
}

\begin{abstract}
The depletion of hydrocarbon resources, which have been the world's traditional energy source for many years, makes it necessary to use alternative and renewable energy sources in the world. The advantage of using energy resources from the sun, wind, biological waste, sea waves and no waste is that there are no environmental problems and the environment is not polluted with any harmful waste.

Alternative energy is not only important for environmental protection. It also softens the dependence of countries, territories and economic systems on oil and its price. It is estimated that in the future, alternative and renewable energy sources in the world will be the fastest growing energy source compared to traditional energy sources due to ETT and high advanced technologies.

The use of non-traditional energy sources is based on two important conditions: the renewability of the fuel source and its availability in a given area. Due to the number of sunny and windy days,
\end{abstract}


Azerbaijan has favorable opportunities in terms of inexhaustible energy potential - renewable natural resources. By building power plants with a capacity of up to $3,000 \mathrm{~kW}$ in the field of solar energy, it is possible to save 13,000 tons of conventional fuel per year, reduce carbon dioxide in the atmosphere by 23,000 tons. The annual potential capacity of wind energy in our country is $800 \mathrm{MW}$, ie 4 billion $\mathrm{kWh}$. This is 1 million tons of conventional fuel per year, 3.7 million. tons of carbon dioxide. In addition, the country has other non-traditional energy resources such as biogas, thermal water and sea waves.

The use of alternative energy sources is more promising in areas where this potential is high and conventional fuel resources are scarce. In Azerbaijan, such places can be remote mountain villages and mountainous areas, specially protected natural areas. Almost all territories of Azerbaijan have rich alternative energy resources.

Keywords: renewable energy, alternative energy, hydropower, energy potential, solar energy, power plants, fuel economy, thermal water, sea wave, biogas. 


\title{
ENERGY SECURITY AND ENERGY EFFICIENCY PRIORITIES IN THE REPUBLIC OF AZERBAIJAN
}

\author{
Elshan Hajizade \\ Professor. Doctor of Economic Sciences., Azerbaijan State University of Economics, ORCID ID: 0000-0001-5447-9676, \\ Email: elshan@hajizada.com
}

Introduction: Energy security and related energy efficiency issues are part of the national energy strategy in most economically developed countries. In the modern world, energy security also includes issues related not only to the quantity of consumption, but also to its quality. In this regard, a sustainable socially oriented state does not separate energy security from energy efficiency and considers it an important indicator of the country's level of development. The Republic of Azerbaijan is also among the countries of the world with abundant hydrocarbon energy resources in terms of current and future prospects. Although energy security is ensured in the country, its strengthening and enrichment with elements of energy efficiency are the main priorities of the ongoing reforms. This issue is also of scientific relevance. In this regard, the article deals with issues related to energy security and energy efficiency priorities in the Republic of Azerbaijan.

Material: Providing energy resources increases the importance of Azerbaijan in ensuring energy security of Europe and a number of world countries. This is done by means of its sufficient oil and gas export pipelines. At the same time, the role and importance of the Baku-Tbilisi-Ceyhan export oil pipeline named after Heydar Aliyev is even higher. Azerbaijan is also reacting to the Southern Gas Corridor, one of the largest energy projects in the world. The Trans-Anatolian Pipeline (TANAP) and the Trans-Adriatic Pipeline $(T A P)$, which are part of this corridor, turn it into a more reliable European gas supplier.

In addition to oil and gas resources, other natural energy sources in Azerbaijan are promising. Sunny and windy areas, numerous rivers, thermal waters as a separate energy source open wide opportunities for the creation of alternative energy resources in the country. The liberated Karabakh region is strengthening these opportunities with its green energy potential. Preliminary estimates show that Azerbaijan has about 27,000 megawatt of renewable energy reserves. In general, the country's existing electricity potential is more than 7,000 megawatt, half of which is still unused. However, it should be noted that despite the country's strong energy potential, it is important to do some work to ensure its sustainable and reliable energy security.

In strengthening energy security, problems in the production and infrastructure complex must be eliminated and a more modern system must be established in this direction. Thus, the country's existing oil and gas refineries are not able to meet its demand for fuel and energy resources in all categories. There are still a number of energy products that are imported from abroad. There are also shortcomings in gas processing, treatment and supply in accordance with standards. In order to provide the population with more reliable gas resources, it is important to increase reserves and further expand the active volume of gas storage facilities. The power system also needs a large-scale reconstruction and modernization. On the other hand, the share of renewable energy sources in the total energy balance is slightly less than 2 percent. This means that 0.5 percent of the country's renewable energy potential is still being used. In addition, energy saving and energy efficiency issues are pending. There is an urgent need for extensive institutional restructuring, the establishment of an energy audit institute, the expansion of the use of low-energy facilities, the reduction of losses, the 
adoption of energy saving measures and the expansion of the application of more advanced standards in all these areas.

All this is one of the main goals of energy policy in the Republic of Azerbaijan, and energy security and energy efficiency are at the forefront. In this regard, a new reform process has been launched in the country to ensure the implementation of energy policy. A number of new institutions in the energy sector have been targeted and new development points have been identified. Work has begun on developing a long-term development strategy for the energy sector and a phased transition to a liberal market model based on competition in the energy sector. Along with all this, the country is working in the field of nuclear energy. For this purpose, the "National Center for Nuclear Research" has been established and a 20-MW research nuclear reactor is being built.

The solution of issues related to energy saving and energy efficiency in the Republic of Azerbaijan will be resolved in the legal field with the adoption of the Law "On Rational Use of Energy Resources and Energy Efficiency". This law provides for the efficient and effective use of energy resources. It will establish the legal basis for regulating relations between the participants and bringing the use of energy resources in line with modern requirements and standards. With the adoption of the law, a number of sub-normative legal acts based on international best practices will be developed. The innovations will also address issues such as eliminating unfair competition in the energy sector and increasing transparency in energy efficiency services.

Conclusion: These studies and analyzes once again confirm the high reliability of energy supply in Azerbaijan. However, new concepts and special programs need to be developed to make energy security sustainable and stable in the country and to increase energy efficiency. It is proposed to consider the following priorities in this direction:

- establishment of the country's energy security indicative management system and expansion of the network of energy efficiency services;

- determination of incentive efficiency norms and limits for the purpose of rational use of energy resources in all sectors of the economy;

- development and gradual implementation of the concept of replacing tariff regulation with free pricing mechanisms;

- continuation of measures to improve the regulatory framework that provides favorable market conditions in the energy sector, limiting monopolies;

- expanding energy integration based on national interests and mutually beneficial cooperation with countries and leading companies around the world.

These priorities, which characterize the sustainable provision of national energy security, do not fully cover all strategic measures. It is believed that in the field of practical application, these priorities will be subjected to more fundamental economic justifications, and they will be formed in a structure appropriate to the changing political and economic situation and will be more scientifically logical.

Keywords: energy security, energy efficiency, reforms, strategy.

\section{References}

1. Aliev I. Caspian oil of Azerbaijan. Moscow: Izvestiya, 2003, 798 p.

2. Lisenko, V.G. Chrestomathy of Energy Saving. M.: Teploenergetik, 2012, 699 p.

3. Samedzade Z.A. Economic security. // Scientific Works of the International Union of Economists and the Free Economic Society. Volume one. Moscow, St. Petersburg: 1994, p. 178-194. 
4. Sultanov Ch. Electric power industry of Azerbaijan. Baku: Chashyogly, 2013, 223 p.

5. Zerkalov D.V. Energy security. Kiev: Osnova, 2012, 920 p.

6. www.president.az - Official website of the President of the Republic of Azerbaijan.

7. www.elshanhajizadeh.com - Professor Elshan Hajizade's website.

8. www.e-qanun.az. - Legislative acts of the Republic of Azerbaijan.

9. www.iea.org - International Energy Agency. 


\section{CORRELATION OF OIL AND GAS RESOURCES OF THE CASPIAN COUNTRIES}

\section{Gulshan Zeynalova}

$\mathrm{PhD}$ of history of the Institute of History of the National Academy of Sciences of Azerbaijan.

The Caspian Sea is the largest body of water in Eurasia: After the collapse of the USSR, the water area of this region is a zone of interest for many states. [1]

The Caspian region rightfully serves as one of the most significant regions for most countries interested in the mineral resources that the Caspian is rich in. The Caspian Sea has a significant hydrocarbon reserves.

According to the Energy Information Administration (EIA), hydrocarbon resources in the Caspian basin have the following values: oil - 48 billion barrels of oil, natural gas - 292 trillion. cubic feet (found and probable reserves), of which $75 \%$ and $67 \%$, respectively, are produced or may be produced offshore.

The northern part of the Caspian Sea contains most of the oil reserves, while the southern sector of the Caspian Sea is rich in natural gas.[2]

It should be emphasized that the list of states that have the rights to use the resources of the Caspian Sea is as follows: Azerbaijan, Iran, Kazakhstan, Russia and Turkmenistan.

It is impossible to correlate the importance of the oil and gas resources of the Caspian reservoir for each of the above countries, for the following reasons: Azerbaijan and Turkmenistan are countries for which the hydrocarbon potential of the Caspian is the most important predictor of the formation and development of the economy, while for Kazakhstan, the use of oil and gas resources of the Caspian Sea plays an important, but not the most decisive role, since oil and gas deposits in this country are not limited to the Caspian region, but its economy is developing in other directions. Iran and Russia, however, are interested in influencing the direction of flows of oil and gas raw materials, including their transit through the territory of the countries. [3]

The last years for the Caspian region have become the years of a shift in the development of the oil and gas industry of the Caspian "five", which account for $17.6 \%$ of oil reserves and $46.4 \%$ of gas reserves in terms of global reserves.

It is assumed that on the territory of the Caspian shelf, which belongs to Russia, oil reserves amount to 270 million tons, natural gas reserves - 0.5 trillion cubic meters. $\mathrm{m}$ of gas. [4]

Of course, it is worth noting that the potential of the Russian sector of the Caspian Sea is significantly lower than the oil and gas potential of Yamal or Western Siberia, but the development of this region is important for the strategic development of the oil and gas sector, in particular offshore drilling.

Oil production in the Russian sector of the Caspian Sea shelf began in 2010 at the Yuri Korchagin field. At the end of 2012, the first Russian millionth ton of oil was produced at the I. Yuri Korchagin. The oil and gas industry is a promising industry not only in the post-Soviet space, but also in other parts of the world. In fact, this industry is strategically important for the Russian state. This is the basis that ensures the stability of the country, and the basis for the development of its economy. [5] As regards Russia, it should also be noted that it is the only country that does without attracting a foreign investor to carry out oil and gas production in the Caspian region. In addition, production activities, which began in the 1990s by OAO NK LUKOIL, emerged without any foundation, despite the fact that the sector, which belongs to Russia, had relatively small reserves of raw materials. Moreover, other 
Caspian countries actively resorted to the help of foreign investors, which has become a practice for the oil and gas industry. It is important to note that state-owned companies have practically no influence: the main projects for the exploration, production and transportation of oil and gas are concentrated in the hands of foreign companies.

Turkmenistan has significant reserves of oil and gas, but, unlike Kazakhstan and Azerbaijan, since independence, the republic has not distinguished itself with serious successes in the development of hydrocarbon resources due to a less favorable investment climate.

The instability of the investment climate led to the fact that large international companies operating since the mid-1990s and investing in a number of projects for the development of hydrocarbons, faced with a host of problems, were forced to leave the country, in particular, ExxonMobil and Shell. Currently, small foreign companies operate in Turkmenistan under the PSA, while the flagship projects of Turkmenistan are less significant in volume and less developed than in Kazakhstan and Azerbaijan.

A number of companies, including LUKOIL and ConocoPhillips, are currently negotiating on participation in exploration and development of structures in Turkmenistan.

According to the official Turkmenistan, the total oil reserves are estimated at 20.4 billion tons, while about half is concentrated in the Turkmen sector of the Caspian Sea shelf - 12 billion tons of oil.

Explored oil reserves of Turkmenistan - 1.7 billion tons, confirmed - 70 million tons. According to the EIA, the potential oil reserves in Turkmenistan are about 5 billion tons, and the proven reserves are 0.07-0.23 billion tons. According to BP estimates at the end of 2011, the country's proven reserves amount to 100 million tons. A number of independent experts, according to the magazine "Oil \& GasEurasia", estimate the explored oil reserves at 0.5 billion tons (Oil \& Gas Eurasia, No. 5, May 2007).

About 170 hydrocarbon deposits have been discovered on the territory of Turkmenistan, of which only one third is being developed. Of the total resources of the Caspian Sea, 32 licensed blocks have been allocated with resources, according to official estimates, oil - 12 billion tons, gas - 6 trillion. $\mathrm{m}^{3}$. Among the countries of the Caspian region, Azerbaijan is most famous for its traditions of oil and gas production. Since the Middle Ages, you can documentarily trace the extraction of "black gold" in the country. [6]

Since gaining independence in 1991, Azerbaijan began to actively attract foreign investment in the country's oil and gas sector to develop rich oil and gas reserves. Azerbaijan has been working for many years to return to its former positions as the center of the oil industry. The signing of numerous contracts with leading foreign oil and gas companies affected the formation of internal political stability and laid the foundation for the economic development of the state, contributing to Azerbaijan's claims to the place of the country as the leader of the region. Today, hydrocarbon raw materials determine the vector of development of modern Azerbaijan, the main principles of the energy policy of which are meeting the country's needs for energy resources and ensuring the energy security of the state.

Azerbaijan ranks second after Kazakhstan in terms of oil reserves. It is oil that has become the country's main asset and strategic resource.

The country's leadership is actively implementing the oil strategy, the essence of which is to invest revenues from the sale of hydrocarbons in other sectors of the national economy, which is carried out through the State Oil Fund of Azerbaijan, an analogue of the Kazakh National Oil Fund.

There are 57 oil and gas fields in Azerbaijan, which are being produced, and 18 of them are offshore. The development of onshore fields has been going on for several decades and to a large extent they have already been depleted, therefore the further development of the industry is aimed at the 
development and development of the deep-sea shelf, where significant volumes of reserves are concentrated and from where most of the production comes.

The largest offshore field is the Azeri-Chirag-Guneshli (ACG) oil field, the reserves of which are approximately 0,9-1,0 billion tons. It is with the ACG field that Azerbaijan's plans for further growth and maintenance of stable production volumes are linked until 2024. Another largest offshore field in Azerbaijan is the Shah Deniz gas condensate field, whose reserves amount to 1,2 trillion. $\mathrm{m}^{3}$ of gas and 240 million tons of condensate. The development of the ACG and Shah Deniz fields is carried out by international consortia, whose members are the world's largest oil companies (BP, ExxonMobil, Chevron, Total, LUKOIL).

Onshore, within the framework of the PSA, the development of the Kursangi-Karabagly, Mishovdag-Kelammedin, Padar-Kharrami, South-West Gobustan, Binagady, Garachukhur, Govsany-Zikh, Pirsaat, Surakhany, and Kyurovdag fields is underway.

As for the promising projects on the shelf of the Caspian Sea, these are the Inam, Yalama, ArazAlov-Sharg, Serdar / Kapaz fields. However, the Araz-Alov-Sharg project is frozen until the issue of the status of the Caspian Sea between Azerbaijan and Iran is resolved, and Serdar / Kapaz is between Azerbaijan and Turkmenistan. [7]

Azerbaijan is also actively developing offshore fields within its sector of the Caspian Sea. At the same time, the place and role of Azerbaijan in the energy map of the region is determined not only by the availability of hydrocarbon resources, but also by the country's unique transit possibilities, which allow transporting resources from Turkmenistan and Kazakhstan.

The leadership in the energy sector in Central Asia belongs to Kazakhstan, given its highest rates of both oil production and the level of energy production in the country. The annual production of this strange oil over the past 5 years has reached the level of 80 million tons from the largest developed oil field Tengiz, as well as the Karachaganak field.

A large resource potential, a balanced and flexible policy of the republic's leadership, a number of liberal reforms in the mid-1990s allowed Kazakhstan to attract significant volumes of foreign investment in the oil industry. The largest transnational companies came to Kazakhstan, which, within the framework of JVs, PSAs (Production Sharing Agreements) and concessions, engaged in the development of the country's largest oil and gas condensate fields, which required large capital investments and the use of the latest development and production technologies, which allowed Kazakhstan to achieve impressive success in implementation. large energy projects.

Kazakhstan has the largest recoverable oil reserves in the Caspian region - 5 billion tons, including the Caspian shelf, and its production in 2015 - 81,6 million tons - accounted for more than 54\% of the oil produced in the region (including Azerbaijan, Turkmenistan and Uzbekistan). Kazakhstan's oil exports are the backbone of the national economy and provide an average GDP growth of over $9 \%$ over the past six years. [8]

In recent years, with the growth of incomes of the national economy against the background of an increase in world oil prices, the national sector, having accumulated enough strength, is more and more confidently gaining places from foreign participants in the largest investment projects, which in the foreseeable future will play a decisive role in the industry. In recent years, with the growth of incomes of the national economy against the background of an increase in world oil prices, the national sector, having accumulated enough strength, is more and more confidently winning places from foreign participants in the largest investment projects, which in the foreseeable future will play a decisive role in the industry. At the same time, national companies enjoy the full support of the government of the republic. [9]

The total projected recoverable hydrocarbon resources of the Kazakh sector of the Caspian Sea are 8 billion tons or 58 billion barrels. 
According to British Petroleum, in terms of proven oil reserves, Kazakhstan (including the Caspian shelf) is in the top ten (9th place) - 5,5 billion tons, which is $2,9 \%$ of the volume of proven oil reserves in the world. In general, in the republic in recent years, a large complex of geological exploration works on the Caspian shelf has been carried out. One of the largest discovered in the world in recent decades is the Kashagan field with recoverable reserves of more than 1,5 billion tons of oil. Fifty companies are involved in oil production in Kazakhstan. Of these, 11 producers are the leaders in oil production with an annual volume of over 1 million tons of oil and gas condensate, which account for $90 \%$ of production.

Most of Iran's deposits were discovered before 1965. At the same time, $70 \%$ of hydrocarbon resources lie on land, and 30\% - on the shelf.

As for the oil and gas industry of Iran, among all the countries of the Caspian "five", its continental shelf is the least studied, which means that its prospects have not been established. OPEC provided data, based on which $13 \%$ of oil reserves and 33,5 trillion cubic meters. m. of natural gas in terms of global reserves constitute Iran's hydrocarbon potential. However, despite this, the country is represented from all the Caspian countries at least in the Caspian Sea. The most promising field in the country is Sardar Dzhangal, which contains 1.4 trillion cubic meters. meters of gas and 10 billion barrels of oil. The company that develops this field is Khazar Exploration and Production Company (KEPCO). It should be noted that Iran uses only one floating platform in the Caspian Sea - Amir Kabir. It is not possible for Iran to develop the subsoil of the Caspian Sea without outside assistance due to many factors. If we talk about the dynamics of production and export of hydrocarbons, then during 2012-14. Experts noted a decrease in levels, which is explained by the imposition of sanctions, but already in 2016 the level of exports and production of hydrocarbons is growing. A feature of the country's oil and gas sector is an urgent need for investments, the introduction of new technological solutions and maintaining the level of renewability of hydrocarbon resources. [10]

Conclusion: Forecasts of oil and gas production and exports remain the driving force behind the development of the energy sector in the countries of the Caspian region and Central Asia. On the basis of these forecasts, national programs for the development of the fuel and energy sector are being developed. Production forecasts are the basis for discussions and advances in future pipeline projects. The new Caspian countries and the states of Central Asia have solved one of the main tasks for themselves - they have attracted funds from foreign oil and gas companies in the energy sector, which acts as a locomotive for economic development. The heads of the new Caspian states paid special attention to the development of oil and gas fields. New pipeline projects have been built or are under discussion, which have secured the countries of the region in the orbit of the interests of the oil and gas business and non-regional states. For more than twenty years of their history, the countries of the Caspian region and Central Asia have created a pipeline architecture that allowed them to export their hydrocarbon resources bypassing the territory of Russia. A significant increase in oil and gas production ensured the filling of new export routes, which became the foundation for the development of the Caspian and Central Asian countries. In the following decades, the countries of the Caspian region and Central Asia intends to continue the implementation of ambitious plans to create new export flows aimed at increasing oil and gas supplies to the external market.

\section{REFERENCES}

1. A.K. Magomedov Caspian - Caucasus - Black Sea region: oil routes, trade routes, war routes (history and modern times) / A.K. Magomedov. - Ulyanovsk: UISTU, 2018 .-- 250 p. 
2. Seyed Hamid Hosseini Horami. Caspian resource and Iran's interests in this region // Theories and problems of political research. 2017. Volume 6. No. 4A. S. 101-112.

3. Cohen A. Russia's gas war // The Washington Times. 2009. 13 january.

4. Serebryakov A.O. Oil and gas resources of the Caspian Sea [Electronic resource]. // Geology, Geography and Global Energy, No. 2 (49), 2013. Access mode: URL: http://www.geo.asu.edu.ru/files/2(49)/80-90.pdf

5. Stepanov D.Yu. Problems of cooperation between the countries of the Caspian region in the oil and gas industry: geoeconomic aspect: Avtoref. dis. Cand. econom. Sciences: 08.00.14 // Diplomatic Academy of the Ministry of Foreign Affairs of the Russian Federation - M., 2008.

6. Katona V.K. Oil and Gas of the Caspian Sea: Between Europe and Asia: Workbook 39/2017 /; Russian International Affairs Council (RIAC). - M .: NP RSMD, 2017 .-- 68 p.

7. Ezhiev I. B. Geopolitics of the Caspian region / I. B. Ezhiev. - M.: Andalus, 2007. - 204 p.

8. Oil and gas resources of Kazakhstan in the system of world and regional relations. Almaty: KISI, 2002, p. 59.

9. Official site of the Ministry of Energy and Mineral Resources of the Republic of Kazakhstan. [Electronic resource]. Access mode: www.memr.gov.kz

10. Seferov A.K., Halova G.O. Cooperation of the Caspian states in the oil and gas sector / In collection. World oil and natural gas markets: increased competition. Ed. S.V. Zhukov - M .: IMEMO RAN ,. 2017 .-- S. 123-131 


\title{
THE ROLE AND IMPORTANCE OF TECHNICAL REGULATION IN INCREASING EFFICIENCY IN THE ENERGY SECTOR
}

\author{
Nurlan Hajizade
}

Dissertant, Institute for Scientific Research on Economic Reforms. "Azerbaijan Institute of Standardization", Head of departament. ORCID ID: 0000-0003-2158-5362, E-mail: hajizadeeh@mail.ru

Introduction: One of the important vectors of economic development in the modern world is the minimization of the negative consequences of human economic and other activities. Therefore, highly developed countries impose mandatory and voluntary requirements on the development of products and implement a series of measures. Necessary regulatory activities of the state in this direction include the definition of mandatory requirements, their proper implementation and the application of sanctions. All these processes are carried out through technical regulation. It is important to apply technical regulation in every sector of the economy. This importance plays a special role in the energy sector, which is closely linked to all sectors of the economy, and differs even more. In this regard, the role and importance of technical regulation in increasing the efficiency of the energy sector in the research work is highlighted.

Material: Statistics show that the number of cases of serious damage to health when using dangerous products is still quite large. According to The European Union's "Rapid alert system for dangerous non-food products", the European Commission receives daily warnings from its national authorities about dangerous products found in the markets. Technical regulation is one of the most important documents of the World Trade Organization as a principle for the world community. The Agreement on Technical Barriers to Trade, which regulates these purposes, stipulates the inadmissibility of the creation of additional barriers to international trade and uses the term "technical regulation". Issues of technical regulation are widely reflected in the normative legal acts of a number of other countries, including the legislation of the Republic of Azerbaijan. All issues in this direction begin with the "Law of the Republic of Azerbaijan on Technical Regulation" adopted in 2019 .

Technical regulation is a type of management that involves the use of legal tools to implement the socio-economic policy of the state. Its axiological bases are aimed at maximum integration of the national market into the world economic system and ensuring compliance of mandatory requirements for products with international norms and rules. This, in turn, implies economic growth of the state. In the economic sphere, technical regulation is seen as an information asymmetry and also as a reaction to classical market failures due to external influences.

Technical regulation includes legal relations in the following three areas:

1. Definition of mandatory requirements for the product:

2. Application of product requirements on a voluntary basis:

3. Conformity assessment.

The first of these three elements of technical regulation is implemented through the adoption and application of technical regulations for products. The second covers standardization. The third is through certification and a declaration of conformity.

Technical regulation should provide a basis for solving two complex issues:

1. Regulation of the domestic market.

2. Creating favorable conditions for the development of foreign trade. 
Technical regulation is also important in the energy sector. The analysis of the materials shows that the policy of technical regulation in the energy sector should give priority to technical, technological and environmental safety

Conclusion: The analysis of the role and importance of technical regulation in increasing the efficiency of the energy sector also gives grounds for the following conclusions:

- It is necessary and effective to expand the application of technical regulation in the energy sector;

- technical regulation policy in the energy sector should cover technical, technological and environmental safety;

- technical regulation in the energy sector, along with a single mechanism, should be based on the separate requirements and characteristics of the first and second links of activities in the sector;

- Technical regulation in the energy sector should combine general and specific principles that ensure the interaction and safe operation of economic entities;

- The system of technical regulation in the energy sector should be formed on the basis of the existing regulatory and technical support framework, taking into account positive international experience and the requirements of leading world institutions;

- Technical regulation in the energy sector should be improved, taking into account the conditions of market relations, as well as its natural monopolistic nature.

Research shows that there is a great need to develop a separate concept that defines technical regulation in the energy sector. In developing it, the economic and geographical parameters of the country and the factors related to the structure and development of production relations must be taken into account. This concept should include the basics of sectoral public policy, goals and objectives, the legal framework for development, the scope of participants, the scope of implementation, standards and technical regulations, the financial apparatus, the organizational landmarks. At the same time, this work should be based on the balance of interests and partnership of government agencies and companies, and should be regulated by precise coordination mechanisms and a relevant coordination body, such as a delivery unit.

Key words: economic development, energy sector, technical regulation, standardization, confmity assessment.

\section{REFERENCES}

1. Boridko S.I., Dementiev N.V., Tikhonov B.N. Metrology and electroradiometry in telecommunication systems. Moscow: Hot Line -Telecom, 2007, 374 p.

2. Okrepilov V.V. Economics of quality for sustainable development. St.Petersburg, Publishing House of Peter the Great St. Petersburg Polytechnical University, 2015, 302 p.

3. Nieminen E.A., Karpash M.O., Minakova A.A., Tatsakovich N.L. Methodological basis for reforming the system of technical regulation in the oil and gas sector of Eastern Europe and the Caucasus. Electronic scientific journal of oil and gas business. Ufa: 2011, № 3, p. 371-382.

4. Novitsky N.I., Oleksyuk V.N. Product quality management: Textbook. Minsk: New Knowledge, 2001, 238 p.

5. www.elshanhajizadeh.com - Professor Elshan Hajizade's website.

6. www.europa.eu.int - European Union.

7. www.wto.org. - World Trade Organization.

8. www.e-qanun.az. - Legislative acts of the Republic of Azerbaijan. 


\title{
PROSPECTS FOR THE DEVELOPMENT AND REHABILITATION OF TOURISM IN THE POST-WAR PERIOD
}

\author{
Farhad Babayev \\ UNEC, master \\ Email: Fbt186@gmail.com, fbt186@outlook.com
}

\begin{abstract}
Problems related to the tourism sector are quite relevant in modern times, and it is necessary to identify solutions to the problems of this area in accordance with the challenges of the time. Especially during war periods, the tourism sector was paralyzed, and it took a lot of time and resources to rehabilitate its activities in the post-war period, to restore the pace of development of this particular sector. Regional economic, political and geopolitical stability play an important role in the diversification of tourism, and I would like to pay more attention to the development and rehabilitation of tourism in the post-war period, which is one of the current problems of the mentioned sphere.[1] I personally conduct this research on regional tourism - on the basis of Caucasus region, especially in Azerbaijan area.

The development of regional tourism is a complex process and involves many factors. The development of regional tourism depends not only on the economic and political stability of a country, but also on the existence of geopolitical stability in all countries bordering on that country, as well as on the relations between these countries. Planning, forecasting, management, marketing, socio-economic processes and their impact play a significant role in the development of regional tourism. Factors influencing the development of regional tourism, along with scientific approaches in the work process, practical approaches including international experience are quiet effective as well.
\end{abstract}

Keywords: tourism, war, postwar, postpandemic, development, region, problems, challenges, international experience, etc.

Methodology: In the course of the study, not only tourism-related services and other activities were summarized and analyzed, but also services and other activities that are indirectly intersecting with tourism and their impact on regional tourism in the post-war period were integrated and evaluated.

In order to clarify the nature of the problems, a number of methods were preferred, including those related to the functions of the field - tourism: cultural, perception, worldview and production functions. [5]

Experience shows that during the post-war period, excursions are first organized in the liberated territories. Excursions are mostly provided becouse people can be intersted to see the caused damages and current situation of the area right after the war. There are both advantages and disadvantages to organizing these events. Following can be mentioned as the disadvantages of such organizations.

- Adverse events that may occur during excursions organized without full security will create mistrust and insecurity in the organization of large-scale tourism in the liberated areas in the future;

- Excursions are conducted between limited groups and planned segments, which may prolong the time that will be spent on recognition and promotion of the liberated territories among wider segments.

- Excursions do not provide ample opportunities to demonstrate the touristic potential of the region. 
Features that can be classified as advantages:

- Excursions allow for initial acquaintance

- Gains political dividends

- Excursions provide an opportunity to determine the tourist potential regions.

However, it is known that the concept of tourism is different from the concept of excursion, as well as tourism is different from the concept of recreation, and the reason for that is that tourism is a more broader concept than other two.[4] However, in the post-war period, using the intersections of excursions, recreation and tourism for tourists, it is possible to create an important multi-vector system that will contribute to the development of the tourism sector as a whole, to organize systematic and comprehensive measures.

The current situation: History shows that wars completely paralyze all areas of human activity, including tourism. However, it is the field of activity that was rehabilitated at the latest during the post-war period, which requires large investments and funds for its rehabilitation, and which returned to its previous potential after the development and full recovery of most areas. Because tourism is not just about the existence of beautiful nature or ancient historical monuments, tourism is a complex area with all the infrastructure of the region, it pursues the development of areas that were destroyed and destroyed after the war, and it is impossible to restoe tourism until the development of showed spheres is completed.

Tourism is such a sensitive and specific field that its activities are being impacted by not only wars, but also by global, regional or internal economic crises, natural disasters, industrial disasters, pandemics (Covid-19 pandemic). [10] Economy estimated the loss of the global tourism at more than \$ 1.2 trillion. 120 million jobs are at risk in the tourism sector. If it is desired to make the development of tourism permanent and dynamic, it is necessary to protect this type of activity from the influence of all the factors I have listed above and even not listed, but is it possible?[12]

As you know, Azerbaijan is currently experiencing a post-pandemic period as well as a post-war period. The most priority issue that we face in the post-war and post-pandemic period is the resumption of tourism in Azerbaijan as a whole after the pandemic, in the liberated territories after the war - in Karabakh. The specificity of the situation that Azerbaijan deals with is that, it faces both of the most important and large-scale impacts on tourism. Although the war period is short, it is much cleare to see the ways of solutions of the post-war situation in the long run. [14]

On a global perspective, tourism fell to a minimum in 2020 due to the pandemic, together with this the July events in Azerbaijan (Armenia's military intervention on the Azerbaijani border), the Patriotic War, which began on September 27 and lasted 44 days, paralyzed tourism significantly. [14] However, in the last 5 years before the pandemic and the war, the regional tourism sector was developing steadily, and this sector was characterized as one of the dynamically developing non-oil sectors of our country in the post-oil era. In general, the availability of possible tools of state support for the tourism sector in our country has had a positive impact on the formation of new types of regional tourism, service enhancement, staff professionalism, strengthening of the possible infrastructure in the most remote regions. The "Strategic Roadmap for the Development of the Specialized Tourism Industry in the Republic of Azerbaijan" that was established by the President, dated March 16, 2016 lead to formulation of strategic vision until 2020, and identified long-term goals covering the period up to 2025 and beyond. [12]

In the post-war period, the most important priority in the development of tourism was the prospects for the development of various areas of tourism in the liberated Karabakh and seven surrounding regions. This was possible though several steps:

- identify and eliminate problems with efficient time management 
- identify and analyse the region's potential

- promotion of tourism opportunities at international exhibitions

- re-harmonization of acts

- adoption of new regulatory normative legal acts

- establishment of management and control mechanisms, and most importantly, security.

Along with a comprehensive approach to the development of tourism in Azerbaijan, the specificity of each region enforces to use the specifics of Karabagh and surrounding areas to identify potential areas for tourism development for each region.

It should be noted that discussions are being held and new mechanisms are being identified for the formation and implementation of development trends in the tourism sector around the world, including regional tourism in the post-pandemic period. Experts of the World Tourism Organization consider the importance of intensifing activities to revive tourism in the post-pandemic period and provide new competitive services. The opportunities for the development of the tourism sector in our country, especially in Karabakh in the post-war conditions, are being assessed. It is believed that a clear mechanism for the activities and prospects of development of domestic tourism in Azerbaijan during the pandemic and war should be developed and presented to the relevant agencies and the public. At the same time, the negative impact of the pandemic and war on the tourism sector and the global competitiveness of regional tourism must be objectively assessed.

Current problems: This is an absolute truth that war destroy the whole possible existing systems. Regardless of the outcome, it has an impact in all areas of all spheres. Historically, the world's most tourist centers, tourist paradises with high tourism potential or rapid dynamics became desirable for decades as a result of war. The scale of World War I and its aftermath put not only tourism at risk but also reduced the standard of living. People's dreams were not about planning their future goals, at the end of the day they had only one dream and that was to survive. Global geopolitical events after World War II reshaped the world map; whether it was the strengthening of the USSR, the Cold War, the hyper-power of the United States, the rapid development of China, the rebuilding of Germany and Japan after defeat and today's transformation into a superpower, or the radical changes on the Asian map after the collapse of the USSR in the 1990s, local wars, the Iraq-Iran war, the wars in the former Yugoslavia, the Egyptian-Israeli war, the Iraq-Kuwait war, and the decades-long civil war in Syria and Libya have largely destroyed tourism existing in those regions. [5]

As a result of the recent civil wars in Syria and Iraq, the region was turned from a tourist paradise due to it's historical heritage into the most undesirable region for tourist. With the occupation of ISIS in Syria and Iraq, Assyria, the ancient cities of the Sumerians, hundreds of historical monuments that were inscribed on the UNESCO World Heritage List, the cities of Palmyra and Nimrod, which maintained survivial for thousands of years, were destroyed by ISIS. The ongoing war and the unstable environment in Iraq have made it impossible to use the region's tourism potential, not only in the above mentioned countries but also in sorroundings.

After the coup in Egypt, one of the most attractive countries in the world in terms of history, climate and warm seas, the flow of tourism in the country stopped for a long time, and the Sheikh al-Sharm tourist center, the pearl of the Red Sea, was almost empty.[8]

Libya's civil war and its spread to neighboring countries have led to a cut in tourism revenues in North Africa today, leading to a sharp decline in incomes, poverty and, consequently, migration. Even today, the unstable political situation in many African countries makes Africa to remain as a continent that has not yet been used to its full potential for tourism. 
All wars have their own causes, sides and specifics. The nature of the war for Karabakh and surrounding areas, which began in the 1990s, was quite different from other local or regional wars. If the First Karabakh War was a war of occupation, in 2020 the 44-day Patriotic War was more of a liberation mission rather than a war. [13]

Right after the liberation mission was completed, the situation was thoroughly assessed and evaluated. The concepts of Smart City, Smart Village and Green City, Green Village was developed in the region. The demining work was started with maximum efficiency. The demining process started to be carried out in order to create conditions for the creation and reconstruction of infrastructure. For the implementation of successive infrastructure projects, President Ilham Aliyev signs the following decrees: [9]

- the establishment of airports in Fizuli, Zangilan, Lachin

- the construction of a new road to Shusha that was declared Azerbaijan's cultural and urban center

- the start of reconstruction in Agdam

- the creation of new hydropower plants,

- the reconstruction of railway lines

- the restoration of historical and cultural heritage.

All the work done is to accelerate the development of tourism in the post-war period to make the region more attractive for tourists.

Post-war: No matter how long the wars last, they end in one way or another - by mutual agreement, peace or the defeat of one of the parties. More serious issues are raised, such as the restoration of war-torn ruins, the creation of normal living conditions for people, the restoration of employment opportunities and the elimination of other problems.

The following are the problems that Azerbaijan must overcome after Karabakh war.

- Full mine safety - After the war in the former Yugoslavia, Croatia was able to clear landmines for 20 years;

- Return and resettlement of more than one million refugees;

- Delimitation and demarcation of borders;

- Rehabilitation of completely destroyed or rendered useless infrastructure;

- Restoration of destroyed natural monuments - Natural sycamore forest located next to the Basitchay in Zangilan region of the Republic of Azerbaijan, was completely destroyed - which was a rare natural sycamore forest in Europe due to its nature, size and type;[7]

- Restoration of completely destroyed, rendered useless, falsified historical and cultural heritage - 5 historical and architectural monuments of world importance during the First Karabakh War, more than 49 historical and architectural monuments of national importance, more than 70 historical and architectural monuments of local significance, More than 20 Monumental and memorial monuments, 30 museum-local lore centers were either completely destroyed, rendered useless or alienated, and formation dates were falsified;[7]

- Rehabilitating illegally conducted archeological excavations and carrying out more in-depth scientific research;

- Re-collection, acquisition, restoration of looted, falsified, destroyed, museum exhibits sold at international auctions;

- Recognition of the region's tourism potential through regular, intensive participation in international tourism exhibitions ;

- Ensuring compensation for exploited natural resources within the legal framework; 
- In general, the requirement and provision of compensation for damages within the framework of international law;

- Detection and destruction of drug laboratories that were planted illegally and uncontrolled in the occupied territories;

- Creating a legal framework;

- Application of new concepts;

- Attracting large amounts of funds;

In fact, the problems and difficulties listed above arise after all wars, and their elimination requires a long time, a large amount of financial resources and political will.

Final: It can be concluded that regional tourism, in the post-war period, is an area needs to be studied in a complex way with its own models, conceptual systems and subsystems. In this sense, the issues can consists of a number of topical areas that have not yet been explored, or a set of less explored sectors. Here we can consider the importance of generalizing our views and suggestions on a number of issues:

- First of all, conceptual approaches to the development and faster rehabilitation of tourism in our country and in the liberated region in the post-war conditions should be formed and mechanisms of action adequate to global pressures should be developed and applied;

- In order to diversify the development of tourism in the region, serious attention should be paid to the organization of Regional Tourism and Recreation methods, in this regard, cooperation with tourism companies and potential investors in the region should be strengthened;

- It is important to apply more effective state support mechanisms for the formation and development of a competitive infrastructure network for tourism that meets world standards;

- In order to ensure the financial stability of regional tourism and in order to meet the demand for working capital and to increase their competitiveness in the post-war conditions, it is expedient to determine tax incentives;

- It is necessary to study the tourism activity in the post-war period on a scientific and methodological basis, to improve the state policy in this field

- In order to intensify the dynamics of tourism development and increase efficiency in the post-war period, measures should be taken to strengthen "public-private sector" cooperation, to ensure financial and credit access to private tourism entities;

- In the post-war period in the Karabakh region, to consider development and implementation of the "State Program to increase the competitiveness and sustainability of tourism in the liberated regions in 2021-2025," etc.

\section{REFERENCES}

1. Law of the Republic of Azerbaijan on Tourism. Baku, June 4, 1999, № 674-IQ.

2. The strategic roadmap for the development of the specialized tourism industry in the Republic of Azerbaijan was approved by the Decree of the President of the Republic of Azerbaijan dated December 6, 2016.

3. Soltanova H.B. Tourism and its development in the Republic of Azerbaijan. AzTU, Baku. 2015. -475 p.

4. ILGAR HUSEYNOV, NIGAR AFANDIYEVA “Organization of tourism work” Baku 2007

5. Bilalov B.A. Tourism management. Baku, 2005 
6. Siyavush T. Eganly, EM Gadzhiev. International tourism and tourism development in the Republic of Azerbaijan. Baku 2003, p. 180.

7. Historical monuments of Azerbaijan. Baku 1958

8. www.wikipedi.org internet encyclopedia

9. Orders and decrees of the President of the Republic of Azerbaijan

1. www.preresent.az

2. 10.https://azertag.az/xeber/BMT_nin_Umumdunya_Turizm_Teskilati_postpandemiya_dovru nde_turizmin_dirchelmesi_istiqametinde_fealiyyet_gosterecek-1568781.

3. 11.https://report.az/turizm/turizmin-inkisaf-perspektivlerinin-deqiq-mexanizmi-hazirlanacaq/.

4. 12. https://az.trend.az/business/tourism/3296457.html.

5. 13.https://azertag.az/xeber/Kompleks_tedbirler_gormekle_6_8_il_erzinde_Qarabag_turizmin in_85_faizini_qura_bilerik-1703129 


\title{
FORECAST POTENTIAL OF HYDROCARBON EXPORTS BY THE CASPIAN COUNTRIES AND METHODS OF THEIR TRANSPORTATION.
}

\author{
Gulshan Zeynalova \\ PHD candidate of the Institute of History of the National Academy of Sciences of the Republic of Azerbaijan.
}

\begin{abstract}
With the collapse of the USSR and the formation of new independent states in the post-Soviet space, the Caspian region gradually turned into a geopolitical space in which focused the attention of the leading world powers. Development the region since that time has led to its dramatic change with the transformation into one of the notable factors of global politics and economy. The key factor that largely determines the condition and development of the economic potential of the Caspian region and hydrocarbon resources are also influencing the geopolitical processes around it. The active development of oil and gas fields in the Caspian region initially raised the issue of ensuring the transportation of hydrocarbons with the aim of exporting them to foreign markets. At the same time, special emphasis is placed both on the expansion of the throughput capacity of the currently operating pipelines and on the implementation of projects for the construction of new ones. The formation of a single transport space based on the balanced development of an efficient transport infrastructure seems to be one of the most serious issues, in a positive solution of which all the Caspian countries, without exception, are interested.
\end{abstract}

Introduction: Considering the issue of the potential of export supplies of oil and natural gas by the Caspian countries, it is necessary to provide general data on the formation of demand for this hydrocarbon raw material.

Oil export directly depends on the amount of oil production in the Caspian fields, so it is worth considering the fact that at the moment the volume of oil in the region directly depends on the potential of the huge oil fields in the region, and if any problem associated with the development of these fields (political, economic or technical) will affect the volume of oil produced, and hence the value of exports. The Caspian Sea region will remain attractive due to unchanged world prices for oil and oil resources.

Unlike oil exports, gas exports are influenced not so much by the volume of production of a given hydrocarbon as by the demand and needs of the market. Experts note that the reserves of natural gas in the Caspian are large, and the peak in blue fuel production is predicted in 2025. The forecasts for the production of both oil and gas of the International Energy Agency are as follows: the peak of production is 2025-2030, after 2035 the role (share) of the Caspian countries in global exports will increase to $9 \%$. [1]

The region's role as a supplier of hydrocorbones: Despite the existing problems in the development of fields in the Caspian Sea, the oil of the region is considered by the world community as a real alternative as opposed to the supply of hydrocarbons from the Middle East. Export potential of blue fuel of the countries of the Caspian region in the mid-2020s will reach the level of 150-250 billion cubic meters. $\mathrm{m} /$ year with a possible increase up to 300 billion cubic meters. $\mathrm{m} /$ year. This forecast is realistic, provided that the basic results of the main projects in the region are achieved. 
Table 1 shows the forecast data on the export potential of blue fuel by the countries of the Caspian region.

Table1. Potential export volumes of natural gas billion cubic meters

$\begin{array}{lcllc}\text { Country } & 2020 & 2030 & 2040 & 2050 \\ \text { Russia } & 307,5 & 372,3 & 253,9 & 96,8 \\ \text { Turkmenistan } & 72,2 & 101,9 & 152,4 & 82,9 \\ \text { Iran } & 56,4 & 60,4 & 34,9 & 16,9 \\ \text { Kazakhstan } & 11,7 & 6,6 & 0,7 & - \\ \text { Azerbaijan } & 11,6 & 23,7 & 35,1 & 15,4\end{array}$

Thus, given the geographic remoteness of hydrocarbons in the Caspian region from the main sales markets, the transportation of oil and natural gas is acquiring a significant role. The direction of export of oil and gas depends on the whole on the alignment of geopolitical forces of both the countries of the Caspian Sea and other states interested in using the potential of the Caspian hydrocarbons. In general, the subsoil regions are rich in colossal hydrocarbon resources, which can affect both world security and the evolutionary development of world energy markets.

Oil transportation routes of the region: The transportation of oil and gas resources is one of the foundations of the energy policy pursued by the countries of the Caspian region. The transportation routes have a direct impact on the demand for the fuel and energy complexes of the coastal countries, are the object of investment and determine the end consumer. During the existence of the USSR, the Caspian pipeline system did not have a significant export potential due to the fact that the volume of oil and gas that was extracted from the fields was used only for the internal needs of the country. After the collapse of the USSR, Turkmenistan, Kazakhstan, Azerbaijan began to diversify the markets for oil and gas, as a result of which new projects began to be created to ensure the export of hydrocarbons from the Caspian region. The main ways of transporting hydrocarbons in the Caspian are pipeline, tanker and mixed, each of which can reveal its own advantages and disadvantages.

The author of the book "Caspian Pipelines" [2] J. Roberts gave the following classification of the Caspian oil supply routes: northern (Russian), central (Caucasian), southern (Iranian-Pakistani) directions. At the end of the 1990s, experts added the eastern (Asian directions) to this classification. The central (Caucasian, western direction implies the supply of oil products from Azerbaijan to the Black Sea through Georgia and Turkey and further to the Turkish terminals in the Mediterranean Sea.

The northern (European, Russian) direction is characterized by the transportation of oil from Kazakhstan in transit through Russia to Novorossiysk, from Azerbaijan to Novorossiysk.

The eastern (Asian, Sino-Japanese) direction is associated with the supply of Kazakh oil to China and further to Japan. A similar classification can be applied to gas pipelines. The southern (IranianPakistani) direction implies the transportation of hydrocarbons from Azerbaijan to Iran, and from there to Turkey. Also, Kazakhstan's oil is sent through Turkmenistan to Iranian terminals in the Persian Gulf or to Pakistan's Indian Ocean terminals. [3]

Today, the transportation of almost all of the produced Caspian oil through the territory of Russia is carried out through the use of main oil pipelines. It should be noted that the Russian Federation is the owner of a strategically important and technically advanced system of oil pipelines with a length of about 50 
thousand $\mathrm{km}$, a system of pumping stations, reservoirs and a single vertically integrated management structure, which is implemented through the Transneft company.

Today, a fairly developed network of pipelines operates in the Caspian region, allowing the supply of energy resources both to the EU (several routes) and to the PRC. The main ones are:

1) gas pipelines:

- South Caucasian gas pipeline, route: Baku (Azerbaijan) - Tbilisi (Georgia) - Erzurum (Turkey);

Central Asia - Center;

- Central Asia - China (Turkmenistan - Uzbekistan - Kazakhstan - China).

2) oil pipelines:

- Tengiz (Kazakhstan) - Novorossiysk (Russia) (“Caspian Pipeline Consortium”);

- Uzen (Kazakhstan) - Atyrau (Kazakhstan) - Samara (Russia);

- Kazakhstan-China pipeline;

- Baku (Azerbaijan) - Novorossiysk (Russia);

- Baku (Azerbaijan) - Tbilisi (Georgia) - Ceyhan (Turkey);

The key directions of the existing pipelines in the Caspian region are the Baku-Supsa, Baku-TbilisiErzurum-Ceyhan, Tengiz-Atyrau Astrakhan region-Novorossiysk, Baku-Grozny-Tikhoretsk Novorossiysk oil pipelines, the Baku-Tbilisi-Erzurum gas pipeline.

The South Stream and Blue Stream gas pipelines are designated here in order to clearly demonstrate the significance of the unrealized Nabucco project for the European gas consumption market.

It is worth noting that the South Stream project was rejected by the European Commission, which referred to violations of the Third Energy Project norms, indicating that Gazprom took a monopoly position in this project. The creation of a consortium and the involvement of other transnational corporations in it would give Europe the opportunity to control the activities of the project. At its core, the creation of South Stream was a response to the Nabucco project, which completely ousted Russia from the list of participants in energy relations. The agreement reached between Russia and Bulgaria contributed to the fact that the European countries changed their minds in favor of a new trans-Adriatic gas pipeline project that would bypass Bulgaria.

Here, the main objects of transport infrastructure are the Central Asia-China oil pipelines (Turkmenistan-Uzbekistan-Kazakhstan-China), its separate part Kazakhstan-China (AktyubinskKumkol-Alashankou-Pichan) and the Turkmenistan-Iran gas pipeline (2 lines of the Dovletabat route -Sarakhs-Hangeran and Korpeje - Kurt-Kui).

Launched in 2020 the Trans-Adriatic Gas Pipeline, stretching to Italy through countries such as Turkey, Greece, Albania, as well as across the Adriatic Sea. It is expected that thanks to such a transport infrastructure, about 17\% (about 10 billion m3) of Azerbaijan's gas will be delivered to Italy. This gas pipeline will also become a continuation of the Transanatolian project (Erzurum, Eskisehir, Turkish-Greek border).

Together, these projects serve as an extension of the South Caucasus transport route and will become a link between Azerbaijani gas fields and the markets of other countries, such as Italy, Turkey, Greece, Albania, and even with the markets of Bulgaria and the countries of South-Eastern Europe. The TAPI - "Turkmenistan - Afghanistan - Pakistan - India" gas pipeline also plays an important role. The Turkmengaz company signed an agreement on gas supplies for the next 30 years with the Indian state corporation GAIL Limited and Pakistani private company "InterStateGasSystems" [6]

Projected oil and gas pipelines: In order to increase the export potential of the Caspian states, it is planned to build new oil and gas pipelines. Let's give a brief description of the main projects. 
With the help of this gas pipeline, Turkmenistan between the Azerbaijani and Turkmen coasts of the Caspian) has the opportunity to connect to such important strategic objects as the Southern Gas Corridor (SGC), which consists of the Trans-Anatolian Gas Pipeline (TANAP) and the TransAdriatic Gas Pipeline (TAP), through which Azerbaijani gas will be supplied in transit through Georgia and Turkey to the Greek border and further to Southern Europe.

The Eskene - Kuryk - Baku oil pipeline is a projected oil pipeline with a length of $739 \mathrm{~km}$. Purpose export of Kazakh oil to the ports of Turkey and Georgia. The initial capacity of the pipeline is 23-25 million tons of oil per year with the prospect of growth to 55 million tons per year.

The TAPI gas pipeline is proposed to be extended from the Galkynysh field in the south of Turkmenistan to the town of Fazilka in India. Project parameters: 33 billion m3 / year - throughput capacity, 1,814 km, incl. Turkmenistan - 214 km, Afghanistan - 774 km, Pakistan - 826 kilometers length, December 2019 - commissioning, 10 billion US dollars - the cost part. Although this project does not directly pass through the territory of the Caspian region, it is a very important transport project for Turkmenistan and its fields in the Caspian Sea.

Conclusion: Today, the countries of the Caspian region are investing in expansion projects, as well as reconstruction of trunk pipeline systems, as well as projects aimed at building new expert directions for Caspian oil. The countries of the Caspian "five" are working both towards the delivery of oil products and towards the development of new export supplies.

At the moment, pipeline transport is an important factor in the geopolitical orientation of the Caspian countries, as well as in the development of political and economic ties not only of the Caspian countries, but also of other states (China, USA, etc.).

The presence of significant resources of oil and natural gas, an extremely favorable geographic location for the construction of pipeline transport for the purpose of export supplies of hydrocarbons make the Caspian Sea an "apple of discord" in the geopolitical interests of the Caspian countries and other states. Most of the existing Caspian hydrocarbon reserves are exported along the northern, southern, eastern and western routes. The main ways of transporting hydrocarbons: pipeline, tanker and combined. Today, the Caspian region has a fairly developed network of pipelines, which allow the supply of energy resources both to the EU (several routes) and to the PRC.

\section{REFERENCES}

1. Caspian oil and gas exports are poised for take-off [Electronic resource]. URL: http://www.iea.org/newsroomandevents/news/2011/march/2011-03-15--1.html

2. J. Roberts Caspian Pipelines. The Royal Institute of International Affairs, P. 84. (1996)

3. A.K. Bystrova Transport infrastructure and environmental problems in the Caspian region (production and export transportation of hydrocarbons). M .: IMEMORAN, - 96 p. (2009)

4. Rethink Institute. [electronic resource] URL: http://www.rethinkinstitute.org/linkingthecaspian-to-europe-repercussions-of-the-trans-anatolian-pipeline

5. China's Worldwide Quest for Energy Security. International Energy Agency URL: http://www.allchinareview.com/china-and-central-asia-asignificant-new-energy-nexus

6. TAPI project: Turkmenistan's geopolitical trump card // Russian International Affairs Council (2016) [Electronic resource]. URL: http://russiancouncil.ru/inner/?id_4=7952\#top-content

7. Trans-Caspian gas pipeline. [Electronic resource]. URL: https://en.wikipedia.org/wiki/TransCaspian_Gas_Pipeline 
8. Transportation and storage. [Electronic resource]. URL:https://neftegaz.ru/news/view/154059-Azerbaydzhan-i-Kazahstan-snova-planiruyutpostroit-nefteprovod-Eskene-Kuryk-Baku

9. TAPI gas pipeline. [Electronic resource]. URL:https://neftegaz.ru/tech_library/view/4991Gazoprovod-TAPI 


\title{
ANALYSIS AND ASSESSMENT OF AZERBAIJAN'S EXPORT POTENTIAL IN THE CONTEXT OF ENTREPRENEURIAL ACTIVITIES
}

\author{
Ayten Mekhraliyeva
}

PhD candidate at «International Magistrate and Doctorate Center» (IMDC), Azerbaijan State University of Economics, https://orcid.org/0000-0001-8874-719X, Email: Aytenmekhraliyeva18@mail.ru

\begin{abstract}
Entrepreneurship is one of the most important factors in the formation and development of a market economy, supporting the domestic market. It can solve social problems along with the solution of an important socio-political task - the formation of the middle class, the strengthening of democracy and social institutions, small business. In modern conditions, the intensification of state regulation and the promotion of the development of entrepreneurship, the organizational forms of interaction of government agencies with private entrepreneurship are changing. During this work, there are significant changes in the goals, mechanisms, management apparatus in the combination of state and market regulatory mechanisms, which is necessary to talk about the importance of the analysis of the structure of activities.

In order to accelerate the pace of economic development in Azerbaijan, to apply the improved features of the market economy, the importance of free entrepreneurship, especially innovative entrepreneurship in accordance with the requirements of the time, is very high. Because innovative entrepreneurship allows to increase low production capacity and product quality. The goals and objectives of the research are to study the specifics of the activities of small and medium-sized businesses in Azerbaijan, to identify their origin, principles of operation, and their specific features. It is also the subject of research to determine the main directions of export activities of business entities and their impact on foreign economic activity, the volume of import-export operations and trade turnover of the country.

Keywords: entrepreneurship activity, Azerbaijan's export policy, economic development, SME, market economy,
\end{abstract}

Introduction: Following the current trends in the economic development of the Republic of Azerbaijan, it can be seen that foreign trade relations are growing. In particular, the policy of achieving diversified economic development accelerates the relevance of foreign trade. In general, foreign trade as a concept involves the exchange of goods and services provided by Azerbaijan in trade relations with other countries through the payment of the material value, as well as the import and export to Azerbaijan. Most of the value added in the international economy today comes from international trade, which is more clearly expressed in the opinion of American economist Jeffrey Sachs. Thus, he notes, the economic gain and success of any country depends on foreign trade. No country has been able to form a perfect economy outside the system of modern world economic relations. Foreign trade operations, which act as the primary form of Azerbaijan's international trade relations, were created under the influence of international specialization of labor relations. Such specialization has resulted in the exchange and exchange of goods and services produced in Azerbaijan, as well as in other countries. As we know, in the current situation, foreign trade relations are very important for the Azerbaijani economy. Azerbaijan mainly earns its income from the sale of oil and oil products in foreign trade. Foreign trade acts as a source of income for Azerbaijan and creates great opportunities for economic development and growth. At the same time, the large share 
of foreign trade in the country's revenues creates a certain dependence on the world economic system. The deepening of globalization is also felt in this way [5].

\section{The role of foreign economic relations in the development of the Azerbaijani economy:}

Azerbaijan's economy is undergoing a rapid integration process and is closely involved in building close relations with countries around the world. In particular, trade relations with European countries have been growing rapidly since the first years of independence. It is no coincidence that if we look at Azerbaijan's export statistics, we can see that Italy ranks first as a foreign trade partner. Implemented regional energy and transport-infrastructure projects give a serious impetus to Azerbaijan's economic development. The volume of budget revenues is growing significantly. However, as well as the positive aspects of deep integration into the world economic system, there are a number of negative effects. Thus, the sharp decline in prices on the world market of oil and oil products since 2015 has created very serious difficulties in countries that provide their income through the sale of energy resources in the world [1,2].

Azerbaijan was also among the countries facing these difficulties. Among the difficulties that arose were the depreciation of the national currency, a slight increase in inflation, and a decrease in budget revenues in dollar equivalent. However, as a way out of these difficulties, the government has focused on the supply of goods and services in foreign trade relations from areas presented as the non-oil sector instead of energy raw materials. In particular, various presidential decrees and decrees have been issued to enhance the role of the private sector, as well as development programs. In addition, one of the steps taken to ensure declining public revenues from various sources is the privatization of state property. In particular, in 2016, a large number of state property was privatized. Naturally, as a market economy, Azerbaijan must achieve a statistical "victory" over the public sector in the private sector in accordance with the requirements of the modern economic system. That is, private sector enterprises and all economic entities must play a leading role in ensuring public revenues. This factor will once again have a positive impact on overcoming economic problems, achieving economic growth and improving the living standards of the population in Azerbaijan, which depends on the proceeds from the sale of oil and oil products in foreign trade.

Generally, Azerbaijan's foreign trade turnover has exceeded \$ 30 billion at various times. This in itself indicates the extent of economic potential. During the main periods of trade, especially as shown in Figure 1 below, exports were higher than imports. However, as noted above, trade turnover has generally declined in recent years [4].

However, the country's leadership's quick response to declining revenues and the steps taken to compensate for declining oil revenues have consistently borne fruit. In particular, a number of development programs, roadmaps and government measures related to the implementation of development strategies indicate promising development.

The positive aspects of the intensification of foreign trade operations and diversified exports in Azerbaijan and their role in economic development can be assessed from various aspects. Thus, the role of foreign trade in improving the living standards of the population is measured by the level of their income and the benefits they receive as a result of high-quality standards applied to products. Success in foreign trade is achieved when the quality of products meets at least world standards. 


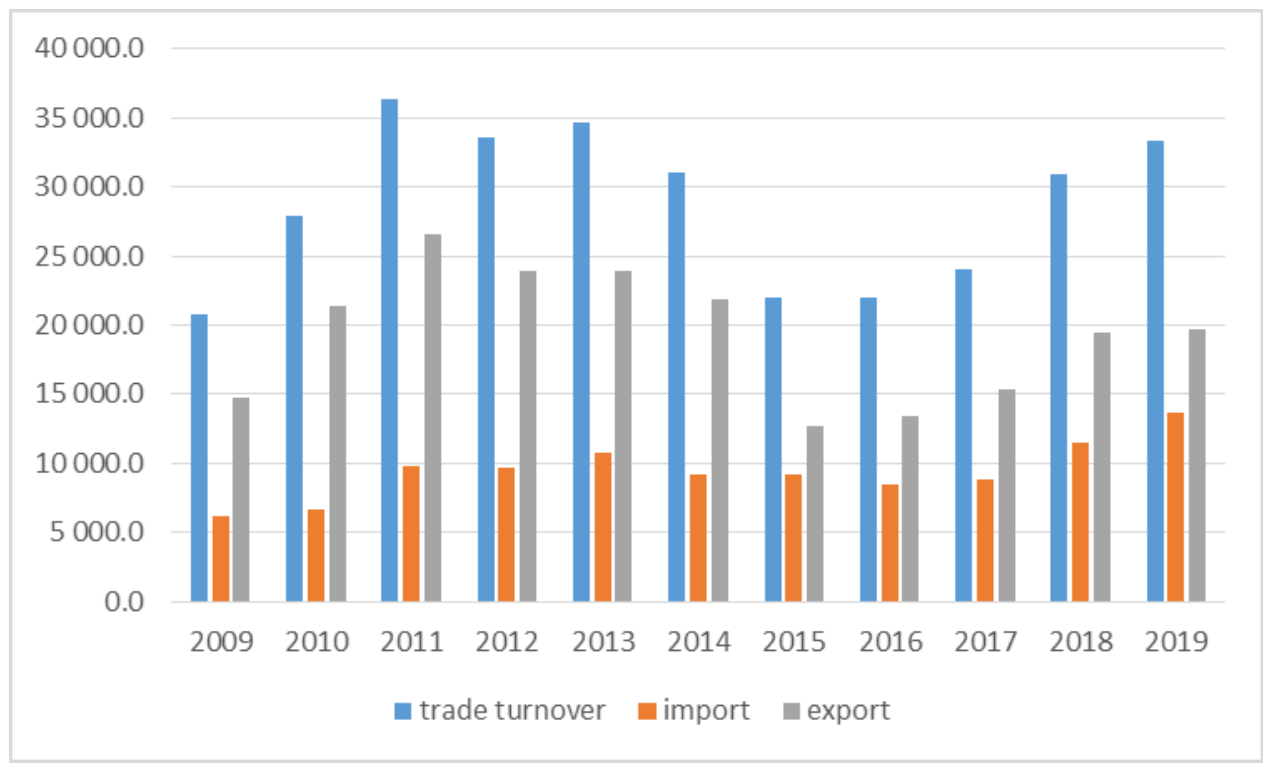

Fig 1. Dynamics of foreign trade turnover (in millions of US dollars)(Source: compiled by the author based on site data https://www.stat.gov.az/source/trade/)

As it's known, a country that is a trading partner buys goods and services in order to meet the needs of its citizens. International trade operations should be understood as the international exchange of various products between many countries. In general, foreign economic relations at the international level are the sphere of international commodity-money relations, the sum of foreign trade of all countries included in the world economic system [6, 7].

Azerbaijan's foreign trade activity consists of two reciprocal processes, export and import. In Figure 1, we observed the total trade turnover, as well as the volume of import and export transactions. These operations also include the share of private sector enterprises. Thus, the main participants in the establishment of international trade relations of Azerbaijan are foreign trade entities, the state itself, industrial and production groups, as well as individuals and others. They can also be called exporters or importers. In general, Azerbaijan's foreign trade relations are assessed as a multifaceted activity.

It should be noted that in international practice, goods traded as objects of trade in foreign trade operations are classified according to their specific features or according to the criteria of product specialization. When looking at economic research and scientific research, it is possible to come across different group classifications. Such classifications reflect different types and forms of foreign trade.

From these classifications we can summarize and present the following:

$>$ foreign trade activities for the sale of finished products;

$>$ foreign trade activities on production machines, as well as equipment;

$>$ foreign trade activities for the sale of raw materials;

$>$ foreign trade activities for the provision of services [8].

Depending on the types of import and export operations carried out by economic entities of the Republic of Azerbaijan, especially with the participation of small and medium enterprises, we can distinguish the following groups of foreign economic trade relations:

1. trade operations on export and import of finished goods; 
2. export of goods and semi-finished products from the country in the form of raw materials for further processing; re-entry into the country after processing;

3. activities on temporary import and export of goods, export of goods to international competitions, exhibitions, presentation events, export from the country for the purpose of demonstration and subsequent re-import;

4. carrying out re-export operations to re-export;

5. Activities on export and import of goods belonging to transnational companies belonging to Azerbaijan;

6. activities on mutual compensation trade between countries;

7. transactions on exchange of goods without currency;

8. cash-based trade and compensation transactions;

9. industry compensation agreements [10].

Assessment of the current state of export operations: Foreign economic relations are a number of directions, forms, methods and means of monetary, financial and credit relations, as well as trade, economic, scientific and technical cooperation between countries to strengthen the advantages of the international division of labor, increase the efficiency of economic and entrepreneurial activities. Foreign economic relations are linked to economics and politics, trade and diplomacy, trade and industrial production, scientific research, credit and financial operations.

Foreign economic relations of business entities cover the following directions and forms [12, p. 245]:

$>$

at five levels:

foreign trade;

international industrial (agrarian and industrial) cooperation;

international investment cooperation;

international scientific and technical cooperation;

economic and technical assistance;

monetary and financial cooperation.

In general, the system of regulation of foreign economic activity operates

$>$ engaged in the export or import of goods and services;

$>\quad$ meso level - the level of various national branches and regional associations. This includes, above all, ministries and agencies directly involved in the regulation of foreign trade, as well as departments and bodies that play an active role in regulating export or import tariff regulation in particular;

$>$

The macro level is the state level. At this level, of course, the government and parliament act as key actors;

meta level - is the establishment of international regional integration customs and tariff priorities. This is especially true of cooperation between the customs authorities during the establishment and development of the Customs Union;

$>$

mega level - regulation at the level of international associations and organizations.

The development trend of foreign economic relations of the world countries shows that foreign economic and trade relations have historically played an important role in changing the socioeconomic situation of states for the better. In the world practice, protectionist trade policy and free trade policy are distinguished depending on the scope of the country's interference in foreign economic and trade relations. Protectionism is a state policy implemented through the use of tariff 
and non-tariff instruments of trade policy to protect the country's domestic market from competition with foreign entities. Free trade relations are a state policy that reflects the lowest level of state intervention in foreign trade, developed on the basis of free market principles under the influence of supply and demand. As we know, in a market economy, the state regulates foreign economic relations in order to ensure economic security and protect the national interests of the country. Depending on the criteria of state regulation of foreign economic and trade activities, it is carried out using a number of methods [11, p. 138]. Methods of regulating foreign economic activity are also included in its system of regulation. These methods include the following:

$>$ economic;

$>$ administrative,

$>$ tariff and non-tariff $[9,11]$.

In Azerbaijan, each method is used in order to stimulate the foreign economic activity of business entities and ensure the intensity of relations. The state provides representatives of business entities with opportunities such as tax, customs benefits, as well as exemption from various duties. Organizational support for export activities of entrepreneurship can also be considered as part of this regulation.

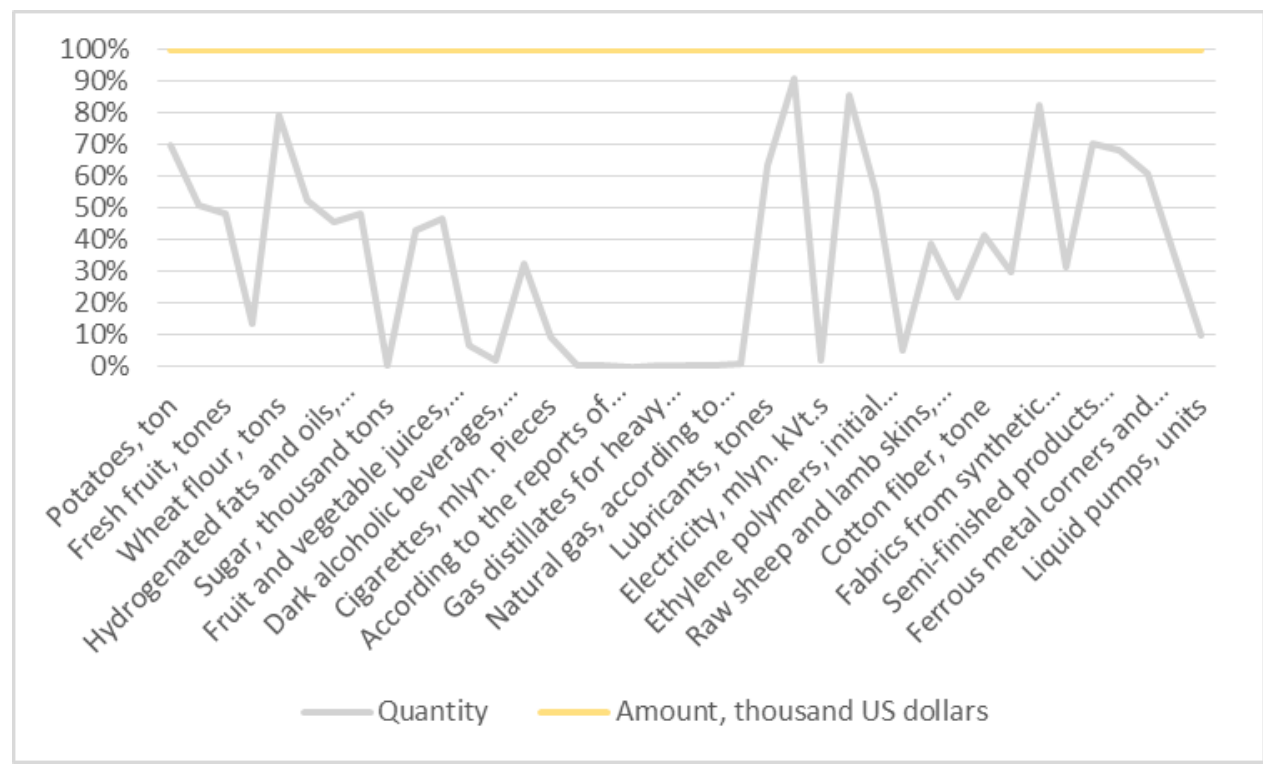

Fig 2. Dynamics of exports of basic goods in percentage for 2019 year.

(Source: compiled by the author based on site data https://www.stat.gov.az/source/trade/)

Taking a view at the main goods what are exported in 2019 year we clearly notice there're many constraints and risks in exports of many products, essentially, paper and cardboard and products made of them, ferrous metal corners and channels, raw sheep and lamb skins, bags and packages of textile materials, wheat flour and etc. (Fig.2).

Within the framework of the support policy, all government agencies serve the implementation of a unified economic policy, i.e., the realization of the country's export potential, as well as reducing dependence on imports, while prioritizing the quality of imported products. One of the tools included in the system of regulation of foreign economic and trade relations of business entities is tariff regulation. We can distinguish the specific features of this regulation in Azerbaijan: 
To increase the efficiency of the commodity structure of import operations carried out by business entities in the Republic of Azerbaijan;

$>$ to control the import and export of products in the Republic of Azerbaijan, as well as the ratio of income and expenses in foreign currency to the amount spent by the country;

$>$ To effectively control the process of import and export of the country's foreign exchange reserves and wealth in the customs territory of Azerbaijan;

$>$ To provide opportunities to ensure efficiency in the structure of production and consumption of goods in Azerbaijan;

$>$ To protect national production entities from negative external influences in the conditions of intensification of competition at the international level;

$>$ To create a fertile environment for the effective integration of the country's economy into the world economic system through the participation of national entrepreneurship and economic entities $[11,13]$.

The system of state regulation of foreign economic relations of business entities in Azerbaijan: The main purpose of state regulation of foreign economic activity of business entities is as follows [13, pp. 156 - 175]:

$>$ Accelerate the improvement of the market economy through the use of foreign economic relations in Azerbaijan;

$>$ Assistance in increasing the quality and productivity of national products through the acquisition of licenses and patents, the acquisition of new technologies, quality components, raw materials and materials, the inclusion of Azerbaijani businesses in global competition;

$>$ creation of conditions for Azerbaijani entrepreneurs to access world markets with the provision of organizational, financial and information support by the state;

$>$ protection of national and foreign economic interests, protection of the domestic market;

$>$ Establishment and maintenance of a favorable international regime in relations with various states and international organizations.

Azerbaijan is perceived as a country with constant reforms and adequate to the changing economic environment. In particular, in order to develop entrepreneurship in the country, to improve the quality of the business environment and economic conditions, to adapt the legislative framework to the requirements of the time, to study and apply national and foreign capital investments, modern technological tools, management practices, as well as high quality. as well as the production of competitive goods and services is one of the priorities of the economic development strategy defined by the country's leadership [14].

As we have noted, the main economic goal of Azerbaijan in recent years is to increase the competitiveness of the national economy by increasing the economic activity of businesses and ensure the sustainability of the dynamic development achieved in the country through the effective integration of the non-oil sector and entrepreneurship.

Entrepreneurship development Along with the creation of a fertile economic environment in the country, it is important to systematically implement state support in the organization of foreign economic relations. The development of foreign economic relations of entrepreneurs depends on the improvement of the system of state regulation of entrepreneurship. Significant work has been done in this direction in recent years. Working mechanisms have been formed to protect the rights of entrepreneurs, and as a result of their implementation, the number of cases of interference has significantly decreased. Regular measures are being taken to strengthen the information and consulting provision of entrepreneurship and to develop business relations. 
At the same time, a mechanism of state financial support for entrepreneurship has been established, and this source is now a real source of meeting the financial needs of small and medium-sized businesses. Within the framework of comprehensive economic reforms implemented in Azerbaijan recently, a lot of important work is being done to realize the export potential of business entities and realize possible opportunities. The introduction of a single online export application in Azerbaijan for the first time in the world is an indicator of the implemented reforms. It should be noted that the representatives of business entities have the opportunity to export goods more easily by filling out a single export application online.

The Single Export Application ensures that representatives of business entities receive all the documents required for the exported goods online in a single window. For the first time in the world, such a step is offered in Azerbaijan, and the relevant service is provided through the Digital Trade Hub and the Azexport portal. Representatives of business entities will be able to export their goods more easily by filling out the Single Export Application online, as well as reduce the time spent on export operations and minimize the amount of money spent. During the implementation of the reform policy, the formation of a fertile economic environment for the implementation of export activities of representatives of business entities in Azerbaijan was accompanied by numerous incentives. Among the measures taken is the establishment of the Internet portal Azexport.az, the Digital Trade Hub and the One-Stop Export Support Center, as well as the launch of operations [15, 17].

The purpose of introducing the possibility of filling out a single export application electronically is to facilitate the work and export procedures of export representatives engaged in small and medium enterprises, to minimize the contact of officials and entrepreneurs in the process of activity. Offering this type of service will also greatly facilitate the issuance of permits for businesses located in different regions of Azerbaijan. It should be noted that the achievement of the above-mentioned process, the system of support for the export activities of business entities and the regulation of their foreign economic relations in general has been the result of long-term purposeful activities. Thus, the legal and regulatory documents adopted in the field of entrepreneurship development, further improvement of the state financial mechanism for entrepreneurship have increased the selfconfidence of business people, stimulated the expansion of entrepreneurial activity, especially the launch of new businesses in the regions. are actively joining.

In addition, the Law of the Republic of Azerbaijan on State Assistance to Small Entrepreneurship is actively used in the regulation of issues related to business entities in the relevant field [14]. This law also reflects the economic methods of regulation. As we know, economic methods are considered more advanced. If we look at the directions of state support for small business, we can see that the issues from the establishment of business entities to the regulation of their foreign economic activity were considered in detail. Let's look at those directions:

$>$ stimulation of small business and creation of development-related infrastructure;

$>$ development and implementation of measures to support small business;

$>$ organization of preferential conditions for small business entities to obtain financial, information, material and scientific-technical resources;

$>$ providing support to small businesses in connection with the creation of qualified human resources, professional development and retraining;

$>$ assistance to economic-foreign, activity of small business entities, as well as development of financial-credit, production, scientific-technical, information and trade relations with foreign counterparts; 
introduction of a simplified system of state registration (accounting), submission of accounting and statistical reports, licensing of their activities and certification of their products (services, works) for small business entities;

$>$ carrying out research related to the development of small business.

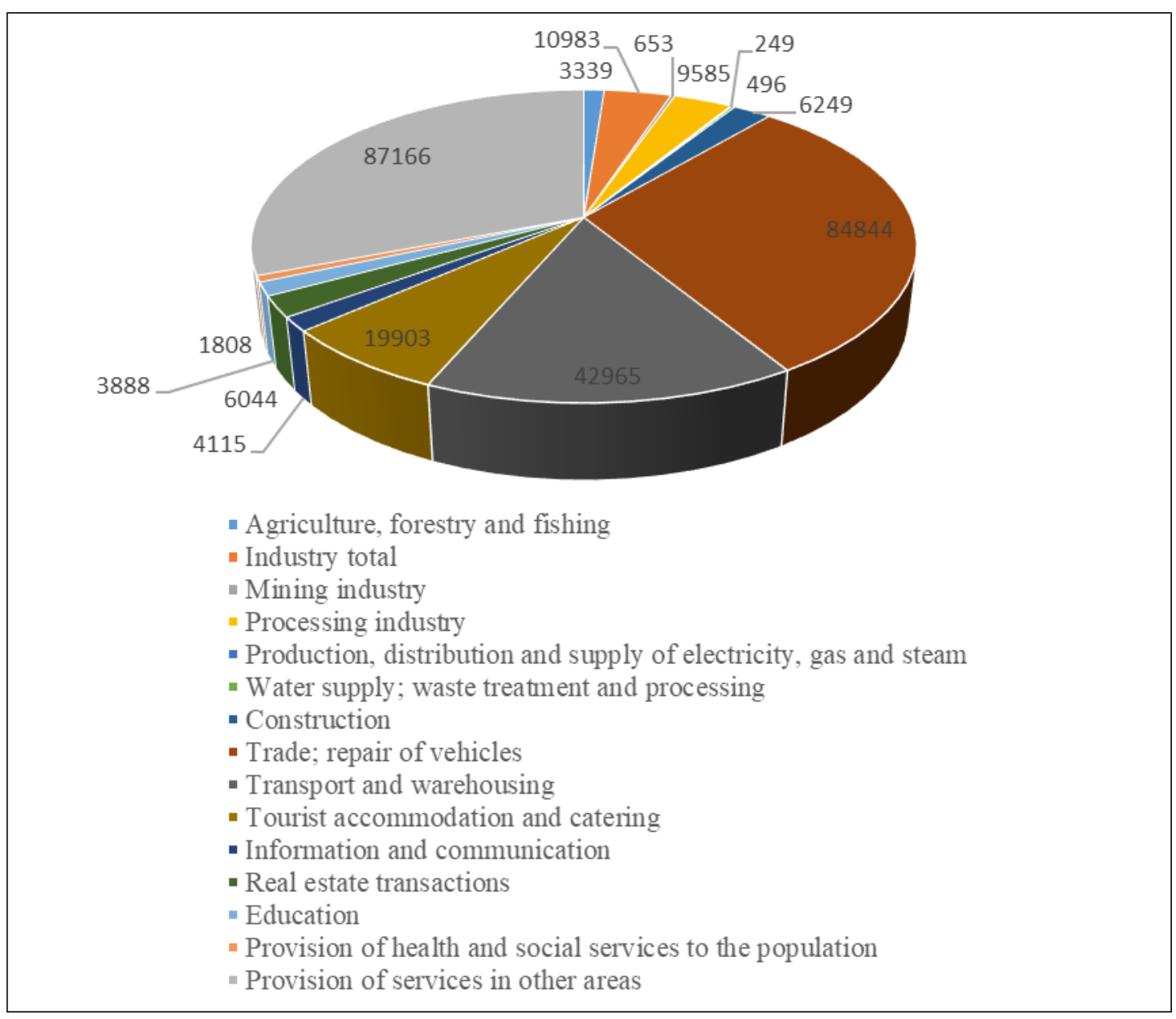

Fig 3: Number of micro-, small and medium business entities operating by economic activity and types of property (Source: Mekhraliyeva A.A. ESD 2021).

The Strategic Roadmap identifies key extents for economic restructuring and progress in SMEs in the short, medium and long period. This study includes a strategic vision for 2020, a long-term vision for the period up to 2025, and a target for the period after 2025. The Strategic Roadmap summaries not only the strategic goals and objects for the pertinent period, but also the priorities set for attaining the goal lines set for those years and the measures to be applied within those priorities. the name of the event, main and other executors, outcome indicators and specific implementation period are reflected $[2,16]$.

Effective implementation of these priorities in the short term will form the basis of the next steps to be implemented in the medium and long term, thus ensuring the efficiency of the implementation 
process. The implementation of the Strategic Roadmap will be ensured through communication and cooperation with non-governmental organizations, local and international private sector partners. In order to achieve the strategic goals, set out in the Strategic Roadmap for the development of SMEs in the country and to ensure maximum use of relevant opportunities, the following have been identified as strategic goals:

$>$ Further improvement of the business environment and regulatory framework in the country in order to increase the impact of SMEs on Azerbaijan's GDP in the long run;

$>$ Ensuring efficient and effective access to financing resources in order to create a sustainable network of SMEs;

$>$ Internationalization of SME activities and increasing access to foreign markets in order to increase the country's foreign exchange reserves and ensure compliance of goods produced in the country with international standards $[3,4]$.

Conclusion: The exchange rate of the national currency - manat - plays an important role in the formation of export potential. The high exchange rate of the national currency in relation to world convertible currencies, as a rule, negatively affects the use of the country's export potential, making imports more profitable. Whereas in conditions of a cheaper exchange rate of the national currency in relation to the dollar, euro, etc., it is profitable to export. Some countries, when determining the exchange rate of the national currency, adhere to its cheapness in relation to other currencies in order to intensify export activities. For the formation of successful foreign economic activity within the country, it is important to achieve sustainable development of the private sector, creating favorable conditions for entrepreneurship, both small and large. The formation of the optimal ratio of the state and non-state sectors of the economy, the oil and non-oil sectors, the production and non-production spheres is of great importance. In the manufacturing sector, it is necessary to increase the share of manufacturing industries, to support innovative production. This also applies to the oil sector, where you can switch to the production of various petroleum products, the development of the petrochemical industry, etc. With regard to agriculture, it is necessary to create and maintain agroindustrial complexes that produce various goods based on agricultural raw materials. Regarding the non-manufacturing sector, it should be noted that it is desirable that a significant place in this area be occupied by scientific institutions, consulting companies. That is, it is assumed a shift from simple services, trade, obits to more complex ones that meet modern requirements, for example, scientific services, business consulting, etc. and entering foreign markets with these services. The above measures will reduce dependence on oil exports, ensuring relatively balanced economic growth [18]. Investigation of the structure and potential export opportunities in the Republic of Azerbaijan can be divided into the following directions, in which its development is advisable:

$>$ develop sectors of the non-oil sector, producing goods that are competitive on the world market;

$>$ support for the development of the agro-industrial complex in the country as an important export industry. This area includes effective specialization in economic regions, the transition to intensive growth, the use of new technologies, the creation of large agricultural firms;

$>$ diversification of the manufacturing industry, the development of such industries as oil engineering, chemical, textile industries, ferrous and non-ferrous metallurgy;

$>$ development of tourism;

$>$ development of high-tech services in the field of information technology;

$>$ incentives for entrepreneurs producing competitive goods to enter the foreign market;

$>$ the creation of free economic zones in border areas to increase the activity of the country's regions and their involvement in export operations. 
implementation of measures of foreign exchange, fiscal and monetary policies that stimulate exports.

\section{REFERENCES}

1. CESD, "Small and Medium Entrepreneurship in Azerbaijan; Country Assessment", 2012, www.cesd.az;

2. Mekhraliyeva A.A. "Fundamental directions of state support for export activities of small and medium-sized entrepreneurship in Azerbaijan", ESD 2021, 10 p.;

3. Decree of the President of the Republic of Azerbaijan on further improvement of management in the field of small and medium business, Baku - 2017.

4. Economic Reform Analysis and Communication Center http://iqtisadiislahat.org/ (date accessed: 08/06/2021).

5. Ed. Bulatova A.S. and Liventseva N.N. (2010), World Economy and Foreign Economic Activity. M - 2010, 654 p.

6. Entrepreneurship Development Fund of the Ministry of Economy of the Republic of Azerbaijan http://edf.gov.az/ (date accessed: 08/06/2021);

7. Law of the Republic of Azerbaijan on Entrepreneurship, Baku - 1992.

8. Law of the Republic of Azerbaijan on state support for small business;

9. Official website of the President of the Republic of Azerbaijan (date accessed: 08/06/2021);

10. Official website of the State Statistics Committee (date accessed: 08/06/2021);

11. Regulation on the adoption of "Rules for the determination of large, medium and small entrepreneurship" Decision of the Cabinet of Ministers of 5 June 2015;

12. Regulation on the adoption of "Rules for the determination of large, medium and small entrepreneurship" Decision of the Cabinet of Ministers of 5 June 2015;

13. Small and Medium-Sized Business: Foreign Development Experience // Young Scientist. 2012. - №4. - p. 177-181;

14. State Customs Committee of the Republic of Azerbaijan https://customs.gov.az/az (date accessed: 08/06/2021).

15. Strategic Road Map on Production of Consumer Goods at Small and Medium Enterprises in the Republic of Azerbaijan 2016;

16. Strategic Roadmap for Financial Services Development in the Republic of Azerbaijan. December 6, 2016;

17. Strategic Roadmap for the Development of Logistics and Trade in the Republic of Azerbaijan", Baku - 2016;

18.Strategic Roadmap for the production of consumer goods at the level of small and medium enterprises in the Republic of Azerbaijan, Baku - 2016. 


\title{
EDITORIAL BOARD
}

\author{
Azerbaijan \\ Adalat Muradov \\ Azerbaijan State University of Economic. Doctor in Economics. Professor. \\ Akif Musayev \\ Correspondent member of Azerbaijan National Academy of Sciences. Doctor in Economics. Professor. \\ Arif Hashimov \\ Active member of Azerbaijan National Academy of Sciences. Doctor of technical sciences. Professor. \\ Arif Mammadzade \\ "Baku Geotechnological problems of oil, gas and chemistry" Scientific Research Institute. Doctor of technical \\ sciences. Professor. \\ Elchin Suleymanov \\ Baku Engineering University. Associate Professor. PhD in Economy. \\ Elshan Hajizade \\ Editor-in-chief. Azerbaijan State University of Economic. Doctor in Economics. Professor. \\ Ibrahim Gabibov \\ Azerbaijan State Oil and Industrial University. Doctor of Technical Sciences. Professor. \\ Lala Bekirova \\ Azerbaijan State Oil and Industrial University. Doctor of Technical Sciences. \\ Mahabbat Mammadov \\ Azerbaijan University of Architecture and Construction. Head of the Department of Service Economics and \\ Management. Doctor in Economics. Professor. \\ Namig Isazade \\ Deputy of Editor-in chief. PhD in Business Administration. \\ Qorkhmaz İmanov \\ Correspondent member of Azerbaijan National Academy of Sciences. Doctor in Economics. Professor. \\ Tahir Jafarov \\ Honorary Professor, International Eco Energy Academy. \\ Vahid Novruzov \\ Chamber of Auditors of Azerbaijan Republic. Doctor in Economics. Professor. \\ Ziyad Samadzade \\ Active member of Azerbaijan National Academy of Sciences. Doctor in Economics. Professor.
}

Georgia

Lia Matchavariani

Tbilisi State University. Doctor of Sciences in Geography. Full Professor.

\section{Poland}

Marcin Kesy

University of Economy in Bydgoszczy. Doctor of Economic Sciences. Professor.

\section{Turkey}

Kerem Karabulut

Ataturk University. Doctor of Economic Sciences. Professor. 


\section{Ukraine}

Alla Kasych

Kyiv National University of Technologies and Design. Doctor in Economics. Professor. Victor Melnyk

Kyiv National Economic University named after V.Hetman. Doctor in Economics. Professor. 


\section{REDAKSIYA HEYəTI}

\section{Azərbaycan}

Akif Musayev

Azərbaycan Milli Elmlər Akademiyasının müxbir üzvü. İqtisad elmləri doktoru. Professor.

Arif Həşimov

Azərbaycan Milli Elmlər Akademiyasının həqiqi üzvü. Texnika elmlər doktoru. Professor.

Arif Məmmədzadə

"Bakı Neft, Qaz və Kimya Sahəsi Geotexnoloji Problemləri” Elmi Araşdırmalar İnstitutu. Texnika elmləri doktoru. Professor

Elçin Süleymanov

Bakı Mühəndislik Universiteti. İqtisadiyyat üzrə fəlsəfə doktoru. Dosent.

Elşən Hacızadə

Baş redaktor. Azərbaycan Dövlət İqtisad Universiteti. İqtisad elmləri doktoru. Professor.

Әdalət Muradov

Azərbaycan Dövlət İqtisad Universiteti. İqtisad elmləri doktoru. Professor.

İbrahim Həbibov

Azərbaycan Dövlət Neft və Sənaye Universiteti. Texnika elmləri doktoru. Professor.

Qorxmaz İmanov

Azərbaycan Milli Elmlər Akademiyasının müxbir üzvü. İqtisad elmləri doktoru. Professor.

Lalə Bəkirova

Azərbaycan Dövlət Neft və Sənaye Universiteti. Texnika elmləri doktoru.

Məhəbbət Məmmədov

Azərbaycan Memarlıq və İnşaat Universiteti. İqtisad elmləri doktoru. Professor.

Namiq İsazadə

Baş redaktorun müavini. Biznesin idarə olunması üzrə fəlsəfə doktoru.

Tahir Cəfərov

Beynəlxalq Ekoenergetika Akademiyası fəxri professoru.

Vahid Novruzov

Azərbaycan Respublikası Auditorlar Palatası. İtisad elmləri doktoru. Professor.

Ziyad Səmədzadə

Azərbaycan Milli Elmlər Akademiyasının həqiqi üzvü. İqtisad elmləri doktoru. Professor.

\section{Gürcüstan}

Lia Matçavariani

Tbilisi Dövlət Universiteti. Coğrafiya elmləri doktoru. Professor.

\section{Poland}

Marsin Kesi

Bıdqoş lqutisad Universiteti. İqtisad elmləri doktoru. Professor.

\section{Türkiyə}

Kerem Karabulut

Atatürk Universiteti. İqtisad elmləri doktoru. Professor. 


\section{Ukrayna}

Alla Kasiç

Kiyev Milli Texnologiyalar və Dizayn Universiteti. İqtisad elmləri doktoru. Professor. Viktor Melnik

V. Hetman Kiyev Milli İqtisad Universiteti. İqtisad elmləri doktoru. Professor. 


\section{REVIEWERS TEAM}

\section{Azerbaijan}

Alijan Babayev

Azerbaijan State University of Economic. Doctor of Economic Sciences. Professor.

Ashraf Alakbarov

Azerbaijan Cooperation University. Associate professor. PhD in Economic Sciences.

Asiman Guliyev

Azerbaijan State University of Economic. Associate professor. PhD in Economic Sciences.

Elmira Balayeva

Azerbaijan Cooperation University. Associate professor. PhD in Economic Sciences.

Elshad Samadzade

Azerbaijan State University of Economic. PhD in Economics. Associate Professor.

Elvin Afandi

Islamic Development Bank. PhD in Economic Sciences.

Fazil Hajıev

Azerbaijan State University of Economic. Doctor of Economic Sciences. Professor.

Fikrat Rahimli

Azerbaijan branch of Moscow State University. Associate professor. PhD in Economic Sciences.

Gabil Manafov

Azerbaijan State University of Economic. Doctor of Economic Sciences, Professor.

Ganimat Safarov

Azerbaijan State Oil and Industry University. Doctor of Economic Sciences. Professor.

Gulshan Yuzbashiyeva

Institute of Economy of Azerbaijan National Academy of Sciences. Doctor of Economic Sciences. Professor.

Ilgar Seyfullayev

Training Center of Ministry of Taxes. Associate professor. PhD in Economic Sciences.

İrshad Karimli

Azerbaijan State University of Economic. Doctor of Economic Sciences, Professor.

Mahmud Hajizade

Ministry of Transport and High Tecgnologies of the Republic of Azerbaijan. PhD in Economics.

Mustafa Sadigov

Azerbaijan State University of Economic. Associate professor. PhD in Economic Sciences.

Rasim Hasanov

Azerbaijan State University of Economic. Doctor of Economic Sciences. Professor.

Yadulla Hasanli

Azerbaijan State University of Economic. Doctor of Economic Sciences. Professor.

Zohrab Ibrahimov

Azerbaijan State University of Economic. Associate professor. PhD in Economic Sciences. 


\section{ROYÇILIR QRUPU}

Azorbaycan

Asiman Quliyev

Azərbaycan Dövlət İqtisad Universiteti. İqtisad elmləri üzrə fəlsəfə doktoru. Dosent.

Elmira Balayeva

Azərbaycan Kooperasiya Universiteti. İqtisad elmləri üzrə fəlsəfə doktoru. Dosent.

Elşad Səmədzadə

Azərbaycan Dövlət İqtisad Universiteti. İqtisad elmləri üzrə fəlsəfə doktoru. Dosent.

Elvin Ofəndi

İslam İnkişaf Bankı. İqtisad elmləri üzrə fəlsəfə doktoru.

Olican Babayev

Azərbaycan Dövlət İqtisad Universiteti. İqtisad elmləri doktoru. Professor.

Әşrəf Әləkbərov

Azərbaycan Kooperasiya Universiteti. İqtisad elmləri üzrə fəlsəfə doktoru. Dosent.

Fazil Hacıyev

Azərbaycan Dövlət İqtisad Universiteti. İqtisad elmləri doktoru. Professor.

Fikrət Rəhimli

Moskva Dövlət Universitetinin Azərbaycan filialı. İqtisad elmləri üzrə fəlsəfə doktoru. Dosent.

Gülşən Yüzbaşıyeva

Azərbaycan Milli EImlər Akademiyasının İqtisadiyyat İnstitutu. İqtisad elmlər doktoru. Professor.

İlqar Seyfullayev

Azərbaycan Dövlət İqtisad Universiteti. İqtisad elmləri üzrə fəlsəfə doktoru. Dosent.

İrşad Kərimli

Azərbaycan Dövlət İqtisad Universiteti. İqtisad elmləri doktoru. Professor.

Qabil Manafov

Azərbaycan Dövlət İqtisad Universiteti. İqtisad elmləri doktoru. Professor.

Qənimət Səfərov

Azərbaycan Dövlət Neft və Sənaye Universiteti. İqtisad elmləri doktoru. Professor.

Mahmud Hacızadə

Azərbaycan Respublikası Nəqliyyat və Yüksək Texnologiyalar Nazirliyi. İqtisad elmləri üzrə fəlsəfə doktoru.

Mustafa Sadıqov

Azərbaycan Dövlət İqtisad Universiteti. İqtisad elmləri üzrə fəlsəfə doktoru. Dosent.

Rasim Həsənov

Azərbaycan Dövlət İqtisad Universiteti. İqtisad elmləri doktoru. Professor.

Yadulla Həsənli

Azərbaycan Dövlət l̇qtisad Universiteti. İqtisad elmləri doktoru. Professor.

Zöhrab İbrahimov

Azərbaycan Dövlət İqtisad Universiteti. İqtisad elmləri üzrə fəlsəfə doktoru. Dosent. 


\section{Jurnal haqqında}

"ENECO - Enerji iqtisadiyyatı Mərkəzinin Xəbərləri” jurnalı (“ENECO” enerji ilə iqtisadiyyati sintez edən bir abreviatura) 2019-cu ildə Azərbaycan Dövlət İqtisad Universiteti - UNEC tərəfindən nəşrə başlamış və həmin ildə Estoniya Milli Kitabxanasında və ölkənin ESTER elektron kataloqunda (E-kataloog ESTER) qeydiyyatdan keçmiş, 2020-ci ildə isə iqtisad elmləri doktoru, professor Hacızadə Elşən Mahmud oğlu ("ENECO" jurnalının baş redaktoru) tərəfindən təsis olunmuşdur (Azərbaycan Respublikası ədliyyə Nazirliyi Mətbu nəşrlərin reyestrinə daxil edilməsi nömrəsi 4322, tarix 27.10.2020-ci il).

Müstəqil, resenziyalı, elmi nəşrdir.

Jurnal beynəxxalq ISSN (Beynəlxalq Standart Seriya Nömrəsi) mərkəzində qeydiyyata alınmışdır (ISSN 2674-4562, E-ISSN: 2674-4597). Obyektin rəqəmsal identifikatoru - DOI suffix: 10.36962/ENECO.

\section{Elmi missiya}

"ENECO" jurnalı həm iqtisadiyyat və həm də enerji sahəsində araşdırmalar və təhlillər aparan tədqiqatçılara, alim, doktorant və magistrantlara öz elmi fikir, mülahizə və qənaətlərini geniş oxucu auditoriyası ilə bölüşmək imkanı yaradan bir platformadır. Jurnalda enerji iqtisadiyyatının müasir problemlərini və sahə üzrə ümumkonseptual məsələləri elmi-metodoloji cəhətdən nəzəri və praktiki uzlaşmada ifadə edən məqalələrin dərcinə üstünlük verilir. Burada həmçinin iqtisadiyyatın digər sahələri ilə bağlı orjinal məqalələr də qəbul olunur.

\section{Jurnalın dili}

Azərbaycan, İngilis və Rus.

\section{Olyazmanın redaksiyaya təqdim olunma qaydası}

Әvvəllər çap olunmuş və ya cap olunmaq üçün başqa bir dövri nəşrə göndərilmiş əlyazmaların jurnala tədqim edilməsi yolverilməzdir.

Әlyazmanın orijinalı mükəmməl redaktə edilmiş elektron formada müəllif(lər)in özü, müxbir müəllif və ya məqalənin göndərilməsinə cavabdeh şəxs tərəfindən elektron məktubla http://sc-media.org/forauthors/submit-a-paper/ veb səhifədə göstərilən sc.mediagroup2017@gmail.com email poçt ünvanına göndərilməklə redaksiyaya təqdim edilir.

Müəllif(lər) redaksiyaya təqdim edilən əlyazma ilə bağlı müvafiq müəllif anketi doldurmalıdırlar. Göndəriş məktubu və müəllif anketinin nümunəsini http://sc-media.org/for-authors/preparation-of-manuscript/ veb səhifədən götürmək olar.

\section{Olyazmanın resenziyalaşdırılması və dərci}

Redaksiyaya təqdim edilən əlyazmalar rezenzentlər tərəfindən konfedensial olaraq resenziyalaşdırıldıqdan sonra onların dərc edilib-edilməməsinə qərar verilir. Resenziyalaşdırma və təsdiqetmə müddəti ümumilikdə 3 aydır. əlyazmalar resenziyalaşdırma prosedurunun nəticələri əsas götürülərək növbəlilik prinsipi ilə dərc olunur.

\section{Müəlliflik hüquqları}

Jurnalda dərc edilən məqalələrdə müəlliflik hüququ qorunur və bu məqalələrin bütün nəşr hüququları eksklyuziv olaraq "ENECO" jurnalına aiddir. Jurnalda cap edilmiş məqalələrin eynilə digər nəşrlərdə dərcinə yalnız Redaksiyanın yazıı icazəsilə, sitatlarların verilməsinə isə mənbə göstərilmək şərtilə yol verilir. 


\section{Nəşrin müəlliflərə təqdim edilməsi}

Məqalə müəllifi(ləri)nə 1 nüsxə jurnal redaksiya tərəfindən hədiyyə olunur. Həmçinin məqalələrinin jurnalda yerləşdirldiyi qaydada tam mətninin elektron formasını jurnalın internet səhfəsindən əldə edə bilərlər.

\section{Olyazmanın strukturu və həcmi}

Әlyazmanın mətni dəqiq strukturlaşdırılmalı, bir sətir buraxılmaq və yeni sətirdən başlamaqla, ardıcıl olaraq, "UOT", "Məqalənin adı" "Müəllifin adı və soyadı" "Müəllifin işlədiyi qurumun adı və ünvanı", "Müəllifin elektron poçt ünvanı", "Müəllifin ictimai identifikasiya nömrəsi - ORCiD”, "Xülasə”, "Açar sözlər”, "Giriş", "Material", "Nəticə", "Әdəbiyyat siyahısı" və xarici dillərdə xulasələr və açar sözlər - "Аннотация", "Ключевые слова" vә "Abstract", "Key words", "JEL Classification Codes" strukturunda tərtib edilməli, həcmi əlavələr, şəkil və cədvəllər daxil olmaqla iki müəllif vərəqi - 80000 işarədən (ara boşluqları nəzərə alınmaqla) - 30 səhifədən çox olmamalıdır.

\section{Olyazmanın tərtib edilmə qaydaları}

Olyazmanın mətni Microsoft Office Word proqramında A4 formatda, Arial - 12 şriftində (qara rəngdə), 1,5 intervalda yığılmalı, səhifələrin bütün kənarlarında $2 \mathrm{sm}$ boş sahə buraxılmalıdır.

Olyazmanın başlığı böyük hərflərlə, yarımbaşlıqları isə yalnız ilk hərfi böyük olmaqla, qalın şiriftlə və nömrələndirilərək yazılmalıdır. Başlıq və yarımbaşlıqlardan, cədvəl və şəkillərdən əvvəl və sonra bir sətir ara boşluğu buraxılmalıdır. Səhifələr ardıcıl olaraq yuxarı sağ küncdə nömrələnməlidir.

Cədvəl və şəkillərin adı olmalı və bu ad cədvəllər üçün cədvəlin üstündə sağ küncdə, şəkillər üçün şəklin altında sol küncdə yerləşdirilərək, ərəb rəqəmlərilə ardıcıl nömrələndirilən, müvafiq olaraq "Cədvəl" və "Şəkil" sözündən sonra yazılmalıdır. Cədvəl və şəkillərin başlıqları ilk hərfləri böyük olmaqla qalın şiriftlə yazılmalıdır. Cədvləin sütunlarının adı qısa olmalı, ölçü vahidləri mötərizədə göstərilməlidir.

Olyazmada istifadə olunan düsturlarda rast gəlinən simvolların qiyməti və ədədi əmsallarının izahı, onların düsturdakı yerləşmə ardıcıllığı nəzərə alınaraq, bilavasitə düsturun altında verilir. Düstur sağ tərəfdə mötərizə daxilində nömrələnməli, hər bir simvolun və ədədi əmsalın qiyməti yeni sətirdə yerləşdirilməli və izahatın birinci sətri "burada" sözündən sonra yazılmalıdır. Tənliklər və düstürlar mətndən boş sətirlər vasitəsilə ayrımalıdır. Hər düsturun üstündə və altında bir-iki boş sətir olmalıdır.

Məqalənin mətnində sözlər, ümumi qəbul edilmiş bir neçə ixtisarlar və çox işlənən akronimlər (və s., məs., ABŞ, BMT) istisna olmaqla, tam açıq verilməlidir.

Mətndə mövzu ilə bağlı zəruri istinadlar olmalıdır. İstifadə edilən bütün mənbələr "Әdəbiyyat siyahısı" hissəsində əlifba sırası, yaxud da istinad olunan ədəbiyyatların mətnində rast gəlindiyi ardıcılıqla nömrələnməli və düzbucaqlı mötərizədə verilməlidir (məsələn: mənbəyə bütövlükdə istinad edildikdə [1] və ya $[3,5,8]$, sitat gətirildikdə [4, s. 17-18]).

Mənbələr müəllif(lər)in soyadı, ad(lar)ının ilk hərf(lər)i, mənbənin adı, nəşr yeri (məqalədirsə - jurnalın adı, məruzədirsə - konfransın adı, kitabdırsa - nəşriyyatın və şəhərin adı), cildi (çoxcildi əsərlər üçün sayı) və səhifə sayı göstərilən strukturda verilməlidir. Xarici dillərdə instinad edilən mənbələrin və internet vebsaytlarının qarşısında onların Azərbaycan dilində açılışını verən tərcümə variantı əlavə olunmalıdır.

Mətndə istinad olunan bütün mənbələr, səhifə nömrələri ilə birlikdə "Odəbiyyat siyahısı" hissəsində aşağıdakı nümunələrdə verilən qaydada göstərilir:

1.Bir və ya bir neçə müəllif kitabları və çoxcildliklər:

Meybullayev M.X. (2010) Mikroiqtisadiyyata giriș. Bakı: "Iqtisad Universiteti”, 2010. $396 \mathrm{s.}$

2.Dörddən çox olan müəllifi olan kitablar:

Qasımov ə.S. və başqaları. (2006) Regionların sosial-iqtisadi inkişaf problemləri (Şəki-Zaqatala regionunun timsalında), Bakı: "Iqqtisad Universiteti” nəşriyyatı, 2006, 304 s.

3.Çoxcildliklər:

"Böyük İqtisadi Ensiklopediya". VII cilddə. / akademik Ziyad Səmədzadənin baş redaktorluğu ilə. Bakı: "Letterpres" nəşriyat evi, 2012-2015. 
4.Toplularda məqaləyə istinad (konfrans, simpozium və digər):

"Azərbaycan iqtisadiyyatında keçid dövrünün başa çatması: təhlil və nəticələr. Milli inkişaf modelinin formalaşması problemləri". (2010) / Respublika elmi-praktiki konfransının materialları. Bakı: "Şərq-Qərb". s. 314-316.

5.Jurnallar:

Hacızadə M.E. İnformasiya iqtisadiyyatı cəmiyyət inkişafının yeni iqtisadi sistemi kimi. AMEA-nın xəbərləri. İqtisadiyyat seriyası. Bakı: №1. 2015, s 24-29.

6.Internet səhfələri (internet səhfələrinə istinadlar mütləq gün, ay, il olmaqla, istifadə olunduğu tarix göstərilmək şərtilə tam adres şəklində olmalıdır):

https://www.stat.gov.az/source/system_nat_accounts/ (11.01.2021) / Azərbaycan Respublikası Dövlət Statistika Komitəsi. Әsas makroiqtisadi göstəricilər.

Mətndə istifadə edilməyən mənbələrə "Odəbiyyat siyahısı" hissəsində göstərilməməlidir.

\section{Xülasə}

Xülasə ayrı-ayrılıqda jurnalın hər bir dilində, eyni məzmunda, həcmi 200 sözdən çox olmamaqla yazılmalı və məqalənin mahiyyətini ifadə etməlidir. Onun mətni elmi və qarammatik baxımdan ciddi redaktə edilməli, burada tədqiqatın məqsədi, metodologiyası nəticələri, məhdudiyyətləri, orijinallığı, elmi yeniliyi, təcrübi əhəmiyyəti əks etdirən fikir və müddəalara yer verilməlidir.

Digər dillərdə verilən xülasələrdə ardıcıl olaraq müəllif(lər)in soyadı, adı, atasının adı, elmi dərəcəsi, işlədiyi qurumun adı, vəzifəsi, elektron poçt ünvanı və məqalənin başlığı göstərilməlidir.

\section{İndeks və açar sözlər}

Müəllif(lər) məqalənin elmi istiqamətlərini UOT indeksi və ABŞ İqtisadi Assosiasiyasının İqtisadi Odəbiyyat jurnalının (The Journal of Economic Literature - JEL) təsnifat sistemi kodları əsasında göstərməlidir. UOT indeksi məqalənin başlığından əvvəl sol küncdə, JEL kodu isə açar sözlərdən (Key words) sonra verilir.

Məqalədə hər bir dildə yazılan xülasənin sonunda 5-dən çox olmayaraq açar sözlər və söz birləşməsi göstərilməlidir. 


\title{
Notes for contributors
}

\begin{abstract}
About Journal
The journal "ENECO-News of the Center for Energy Economics" ("ENECO" is an abbreviation for the synthesis of economics and energy) began its publishing activity in 2019 at the Azerbaijan State University of Economics - UNEC, and in the same year was registered in the Estonian National Library, as well as in the electronic catalog of the country ESTER ( $E$ - catalog ESTER). In 2020, it was established by the doctor of economic sciences, professor, Editor-in-chief of "ENECO" magazine Hajizadeh Elshan Mahmud oglu (Ministry of Justice of the Republic of Azerbaijan No. 4322, date 27.10.2020).

The Journal is independent, refereed, monthly and scientific publication.

The journal is registered in the ISSN International Center (ISSN-2674-4562, E-ISSN: 2674-4597). The digital object ID is DOI suffix: 10.36962/ENECO.
\end{abstract}

\section{Scientific Mission}

"ENECO" is a platform for researchers, scientists, doctoral students and masters conducting research and analysis, both in the field of economics and in the field of energy, to share their scientific views, opinions and conclusions with a wide range of readers. The journal prefers to publish articles that reflect current problems of the energy economy and general conceptual issues in this area in a scientific, methodological, theoretical and practical combination. The journal also pays attention to original articles devoted to other areas of the economy.

\section{Languages of Manuscripts}

Azerbaijani, English.

\section{Rules of Presentation of Manuscripts to the Editorial Office}

It is inadmissible to present articles that published or sent to another edition for publishing.

The author ( $s$ ) himself, the corresponding author or the person responsible for the submission of the article in a perfectly edited electronic form. http://sc-media.org/for-authors/submit-a-paper / shown on the website email: sc.mediagroup2017@gmail.com e-mail is sent to the editorial office. The author(s) must fill out the corresponding author's form. A cover letter and a sample of the author's form can be found on the web page http://sc-media.org/for-authors/preparation-of-manuscript/

\section{Reviewing and Publishing of the Manuscripts}

The Editorial Office decides about publishing of manuscripts after confidential reviewing of manuscripts by Refereed Board.

The period of reviewing and its affirming is 3 months.

Manuscripts are publishing with queue principle in results of procedure of reviewing.

\section{Copyrights}

The published articles are protected by copyright, and all exclusive rights to these articles belong to the editorial board of the journal "ENECO". Reprint of articles published in the journal is possible only with the written permission of the editorial board, and citation - with reference to the source.

\section{Rules for submitting published articles to the author(s)}

The editorial board sends the author(s) one copy of the journal free of charge. The author $(s)$ can also download an electronic version of the full text of the article from the journal's web page in the same form as it was published in the journal. 


\section{Structure and Volume of Manuscripts}

Manuscripts must be consist of sections of "UDC", "itle of article", "name and surname of author(s)", "name and address of organization of author(s), e-mail address of author(s)", "Open Researcher and Contributor Identifier - ORCID", "abstract", "keywords", "JEL classification codes", "introduction", "text of article", "methodology", "conclusion", "references" and "abstracts in other languages" with succession.

Also, volume of manuscripts must not be much from 30 A4 pages or symbol of 80000 (including appendixes, pictures and tables).

\section{Compiling of Text of Manuscripts}

Text of manuscripts must be written in Microsoft Word Office, A4 page format, Arial - 12 punto (black colour), 1.5 line and $2 \mathrm{~cm}$ empty area must be allowed in all edges of the pages.

Title of manuscripts should be capital and bold letters. But subheads should be little letter and numbered. Before and then title, subheads, tables and pictures must be allowed one line distance. Pages must be numbered in the top right corner.

Each table and figure must have a title and a sequence number. The name of the table is placed in the right corner above the table and is written after the word "Table", and the name of the figure in the left corner under the figure and is written after the word "Figure", numbers are written in Arabic numerals. The number and name of the table and figure are written in bold (the first letter is uppercase). Table column names should be short, and units of measurement should be specified in parentheses.

All parameters included in the formula must be decoded. Formula numbers are placed in parentheses to the right. Explanations of the values of symbols and numerical coefficients should be placed directly under the formula in the sequence in which they are given in the formula. The first line of the explanation should start with the word "where" without a colon. Equations and formulas should be separated from the text in separate lines. Above and below each formula, you need to leave one or two free lines.

The text should not contain abbreviations of words, acronyms, except for common ones (etc., e.g. USA, UN). The text should contain mandatory links related to the topic.

All sources used should be placed in the "List of References" section, numbered in alphabetical order or in the order in which they appear in the text. The cited sources are given in square brackets (for example, if the reference is to the complete work [1] or [3, 5, 8], and if it is a quote then [4. pp. 17-18.])

In the list of references contains the following data: initials of the author(s) title source place of printing (if article - name of journal, report, conference title, book - city and full name of the publisher), volume (for multivolume works, the volume number) and the number of pages. For sources and Internet pages in foreign languages, you need to attach a translated version in Azerbaijani.

The sources used in the text should be presented in the part "List of References" according to the following sample:

1. One or more author's books and multi-volumes:

Meybullayev M.X. (2010) Introduction to Microeconomics. Baku: "University of Economics", 2010. 396 p.

2. Books with more than four authors: Gasimov AS and others. (2006) Problems of socio-economic development of the regions (on the example of Sheki-Zagatala region), Baku: "University of Economics" publishing house, 2006, $304 \mathrm{p}$.

3. Multi-volumes: The Great Economic Encyclopedia. In seven volumes / Editor-in-chief of academician Ziyad Samadzade. Baku: Letterpres Publishing House, 2012-2015.

4. Reference to the article in groups (conference, symposium, etc.):

"The end of the transition period in the Azerbaijani economy: analysis and results. Problems of formation of national development model". (2010) / Materials of the Republican scientific-practical conference. Baku: "EastWest". s. 314-316.

5. Magazines: Hajizadeh M.E. Information economy as a new economic system of social development. News of ANAS. Economy series. Baku: №1. 2015, pp. 24-29. 
6. Internet pages (references to web pages must be in the form of a full address, with the indication of the date, month, year and date of use): https://www.stat.gov.az/source/system_nat_accounts/ (11.01.2021) / State Statistics Committee of the Republic of Azerbaijan.

Key macroeconomic indicators. Sources not used in the text should not be listed in the Bibliography section.

\section{Abstracts}

The abstract reflects the essence of the article, is compiled in each individual language of the journal with the same content, and should not exceed 200 words. The text of the abstract should be strictly edited from a scientific and grammatical point of view and should include points of idea and provisions that reflect the purpose of the study, methodology, results, limitations, originality, scientific innovation and practical significance.

Abstracts in other languages must contain the author(s) last name, first name, patronymic, academic degree, name, position, e-mail address and title of the article.

\section{Index and Keywords}

Author(s) must note scientific directions of article on bases of JEL Code (The Journal of Economic Literature of American Economic Association) and UDC index. JEL codes must be noted after keywords, but UDC index must be noted in the left corner of page before title of the article.

Keywords: must not be much from 5 words. 
VOLUME 06 ISSUE 022021

Правила для авторов

\section{О журнале}

Журнал «ENECO - Вести Центра энергетической экономики» («ENECO» - аббревиатура, обозначающая синтез экономики и энергиии) начал свою издательскую деятельность в 2019 году в Азербайджанском Государственном Экономическом Университете - UNEC, и в том же году был зарегистрирован в Эстонской национальной библиотеке, а также в электронном каталоге страны ESTER (E-catalogue ESTER). В 2020 году был учрежден доктором экономических наук, профрессором,главным редактором журнала «ENECO» Гаджизаде Эльшан Махмуд оглу (Министерство Юстиции Азербайджанской Республики № 4322, дата 27.10.2020).

\section{Независимое рецензированное научное издание.}

Журнал зарегистрирован в Международном центре ISSN (ISSN - 2674-4562, E-ISSN: 2674-4597).

Цифровой идентификатор объекта - DOI suffix: 10.36962/ENECO.

\section{Научная миссия}

Журнал «ENECO» платформа для исследователей, ученых, докторантов и магистров, проводящих исследования и анализ, как в области экономики, так и в сфере энергетики, чтобы поделиться своими научными взглядами, мнениями и выводами с широким кругом читателей. Журнал предпочитает публиковать статьи, отражающие актуальные проблемы энергетическоой экономики и общие концептуальные вопросы в этой области в научно-методологическом, теоретическом и практическом сочетании. Также в журнале уделяется место оригинальным статьям, посвященным другим сферам экономики.

\section{Печатный язык журнала}

Азербайджанский, английский и русский.

\section{Форма представления и комплектность материалов}

Статьи, опубликованные ранее или направленные в другие периодические издания, не принимаются. Оригинал рукописи в идеально отредактированной электронной фооме представляется электронным письмом самим автором(ами), автором-корреспондентом или лицом, ответственным за отправку статьи в редакцию на электронную почту sc.mediagroup2017@gmail.com, отображенной на вебстранице http://sc-media.org/for-authors/submit-a-paper/.

Автор должны заполнить соответствующий авторский бланк. Сопроводительное письмо и образец авторского бланка можно найти на веб-странице http://sc-media.org/for-authors/preparation-of-manuscript/

\section{Рецензирование и публикация}

Представленные в редакцию рукописи статей рецензируются в конфиденциальном порядке, после чего принимается решение о публикации или отклонении. Процедура рецензирования и утверждения занимает срок до 3-х месяцев, далее статьи публикуются в порядке очередности.

\section{Авторские права}

В опубликованных статьях авторские права защищаются, и все эксклюзивные права на эти статьи принадлежат редакции журнала «ENECO». Перепечатка статей, опубликованных в журнале возможна только с письменного разрешения редакции, а приведение цитат - при ссылке на источник.

\section{Правила предоставления опубликованных статей автору(ам)}

Редакция высылает автору(ам) один экземпляр журнала бесплатно. Автор(ы) также может скачать электронную версию полного текста статьи с вебстраницы журнала в той же форме, в которой она была размещена в журнале. 


\section{Структура и объем рукописи}

Текст авторской рукописи статьи необходимо точно структуризировать, то есть, пропуская одну строку и начиная с абзаца соблюдать очередность: «УДК», «Заголовок статьи» «Фамилия и имя автора», «Название и адрес учреждения, где работает автор, адрес электронной почты», «Открытый идентификатор исследователя и автора - ORCID», «Аннотация», «Ключевые слова», «Введение», «Материал», «Результаты», «Список литературы» и на английском языке резюме и ключевые слова «Abstract», «Key words», «JEL Classification Codes». Объем статьи, включая иллюстрации, таблицы и дополнительные материалы, не должен превышать 30 страниц - 80000 условных знаков (включая пробелы) - 2-х авторских листов.

\section{Правила составления рукописи}

Текст статьи должен быть набран Microsoft Office Word в формате A4, шрифтом Arial - 12, размером 14 с междустрочным интервалом 1,5, отступы по краям - 2 см.

Заголовки статей пишутся жирными заглавными буквами, а подзаголовки заглавной большой и последующими маленькими жирными буквами. Перед и после заголовка и подзаголовков, таблиц и рисунков необходимо соблюдать интервал в одну строку. Страницы должны быть последовательно пронумерованы в верхнем правом углу.

Каждая таблица и рисунок должны иметь заголовок и порядковый номер. Название таблицы помещается в правом углу над таблицей и пишется после слова «Таблица», а название рисунка в левом углу под рисунком и пишется после слова «Рисунок»; номера пишутся арабскими цифрами. Номер и название таблицы и рисунка пишутся жирным шрифтом (первая буква заглавной). Названия столбцов таблицы должны быть краткими, единицы измерения нужно указать в скобках.

Все входящие в фрормулу параметры должны быть расшифрованы. Номера фрормул располагаются справа в круглых скобках. Объяснения значений символов и числовых коэффициентов надо размещать непосредственно под формулой в той последовательности, в которой они приведены в формуле. Первую строку объяснения нужно начать со слова «где» без двоеточия. Уравнения и формулы надо выделять из текста отдельными строками. Выше и ниже каждой формулы нужно оставлять одну или две свободные строки.

В тексте не должно быть сокращений слов, акронимов, за исключением общепринятых. (и т. д., напр., США, OOH)

В тексте должны быть обязательные ссылки, связанные с темой.

Bce использованные источники должны размещаться в части «Список литературы», пронумеровываться в алфравитном порядке или в порядке появления их в тексте. Цитированные источники даются в квадратных скобках (напр. если ссылка на полную работу [1] или [3, 5, 8], а если это цитата то [4. с. 17-18.])

В списке литературы содержатся следующие данные: инициалы автора(ов), название источника, место печати (если статья - название журнала, доклад - название конференции, книга - город и полное название издательства), том (для многотомных трудов - количество томов) и количество страниц. Для источников и интернет страниц на иностранных языках, нужно приложить переведенный вариант на Азербайджанском языке.

Использованные источники в тексте должны быть представлены в части «Список литературы» по следующему образцу:

1.Книга одного или нескольких авторов и многотомники:

Мейбуллаев М.Х. (2010) Введение в микроэкономику. Баку: «Экономический университет», 2010. 396 с. 2.Книга более 4-х авторов:

Гасымов А.С. и другие. (2006) Проблемы социально-экономического развития регионов (на примере Шеки-Закатальского района), Баку: Издательство «Экономический университет», 2006, 304 с.

3.Многотомники: 
Большая экономическая энциклопедия. В семи томах / Главный редактор академик Зияд Самедзаде. Баку: Издательство Letterpres, 2012-2015.

4.Ссылка на статью в сборниках (конференция, симпозиум и т. д.):

«Завершение переходного периода в азербайджанской экономике: анализы и итоги. Проблемы фрормирования модели национального развития». (2010). / Материалы республиканской научнопрактической конференции. Баку: «Восток-Запад». стр. 314-316.

5.Журналы:

Гаджизаде М.Э. Информационная экономика как новая экономическая система общественного развития. Новости НАНА. Экономическая серия. Баку: №1. 2015, с. 24-29.

6.Интернет страницы:

При ссылках на интернет страницы обязательно должны быть указаны день, месяц, год использования в полном адресном формате.

https://www.stat.gov.az/source/system_nat_accounts/ (11.01.2021) / Государственный Комитет по Статистике Азербайджанской Республики. Основные макроэкономические показатели.

В ссылках необходимо отдавать предпочтение научным источникам за последние 5-10 лет. Не следует включать в список литературы неиспользованные источники.

\section{Аннотация}

Аннотация отражает суть статьи, составляется на каждом отдельном языке журнала с одинаковым содержанием, и не должна превышать 200 слов. Текст аннотации должен быть строго отредактирован с научной и грамматической точек зрения и должен включать пункты идеи и положения, отражающие цель исследования, методологию, результаты, ограничения, оригинальность, научное новаторство и практическую значимость.

В аннотации на других иностранных языках необходимо последовательно указать фрамилию, имя, отчество автора(ов), его ученую степень, место работы, занимаемую должность, служебный и домашний телефоны, фракс, e-mail и заголовок статьи.

\section{Индексы и ключевые слова}

Авторы должны указать научные направления статьи, индекс УдК и коды на основе системы классификации журнала Экономической Литературы Экономической Ассоциации США (Journal of Economic Literature - JEL, www.aeaweb.org/journal/jel_class_system.php). Индекс УДК размещается в левом углу перед заголовком статьи, а код JEL после написанных на английском языке ключевых слов (key words).

После аннотаций статьи, написанных на разных языках, необходимо указать не более 5 ключевых слов и словосочетаний. 


\section{Topics of journal}
A: General Economics and Teaching
F: International Economics
G: Financial Economics
$\mathrm{H}$ : Public Economics
I: Health, Education, and Welfare
J: Labor and Demographic Economics
K: Law and Economics
L: Industrial Organization
M: Business Administration and Business Economics, Marketing, Accounting, Personnel Economics
$\mathrm{N}$ : Economic History
O: Economic Development, Innovation, Technological Change, and Growth
$\mathrm{P}$ : Economic Systems
Q: Agricultural and Natural Resource Economics, Environmental and Ecological Economics
R: Urban, Rural, Regional, Real Estate, and Transportation Economics
Z3: Tourism Economics

Jurnalın mövzuları
A: Ümumi İqtisadiyyat və Tədris
$\mathrm{F}$ : Beynəlxalq İqtisadiyyat
G: Maliyyə İqtisadiyyatı
H: Dövlət lqqtisadiyyatı
I: Səhiyyə, Təhsil və Rifah
J: Omək və Demoqrafik İqtisadiyyat
K: Hüquq və lqtisadiyyat
L: Sənaye Təşkilatı
M: Biznes İdarəetmə və Ticarət İqtisadiyyatı, Marketinq, Mühasibat, Personal İqtisadiyyatı
$\mathrm{N}$ : İtisadi tarix
O: İqtisadi İnkişaf, İnnovasiya, Texnoloji Dəyişiklik və Artım
P: İqtisadi Sistemler
S: Kənd Təsərrüfatı və Təbii Qaynaqlar İqtisadiyyatı, Әtraf Mühit və Ekoloji İqtisadiyyat
$\mathrm{R}$ : şəhər, kənd, regional, daşınmaz əmlak və nəqliyyat iqtisadiyyatı
Z3: Turizm lqtisadiyyatı 
NGO International Center for Research, Education \& Training (Estonia, Tallinn) is publishing scientific papers of scientists on Website and in Referred Journals with subjects which are mentioned below:

(c) The Baltic Scientific Journals

ISSN: 2613-5817; E-ISSN: 2613-5825; UDC: 0 (0.034);

DOI PREFIX: 10.36962/PIRETC

Proceeding of The International Research Education \& Training Center. https://scia.website/index.php/piretc

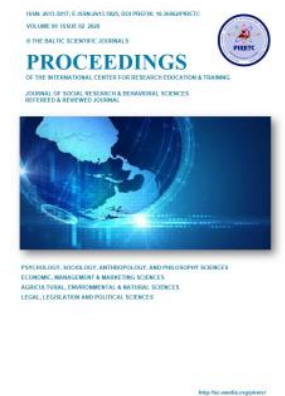

ISSN: 2674-4562, E-ISSN: 2674-4597, UDC: 620.9 (051) (0.034);

DOI PREFIX: 10.36962/ENECO

Proceedings of Energy Economic Research Center. ENECO

https://scia.website/index.php/eneco

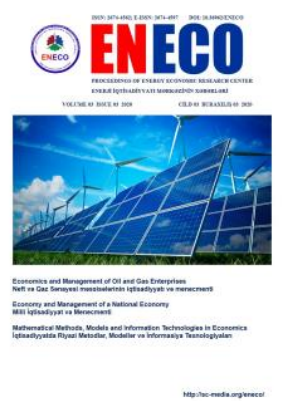

ISSN: 1609-1620, E-ISSN: 2674-5224; UDC: 62 (051) (0.034);

DOI PREFIX: 10.36962/PAHTEI

Proceedings of Azerbaijan High Technical Educational Institutions. PAHTEI

https://scia.website/index.php/pahtei

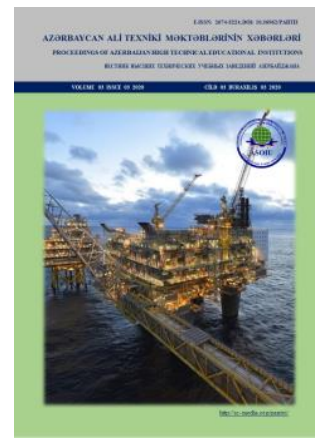


ISSN: 2663-8770, E-ISSN: 2733-2055; UDC:

DOI PREFIX: 10.36962/ETM

ETM Equipment, Technologies, Materials

https://scia.website/index.php/etm

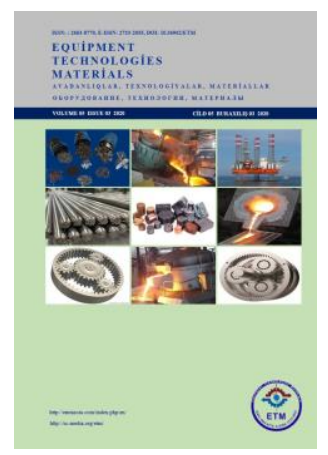

ISSN: 2733-2713; E-ISSN: 2733-2721; UDC:

DOI PREFIX: 10.36962/SWD

SOCIO WORLD-SOCIAL RESEARCH \& BEHAVIORAL SCIENCES

https://scia.website/index.php/swd

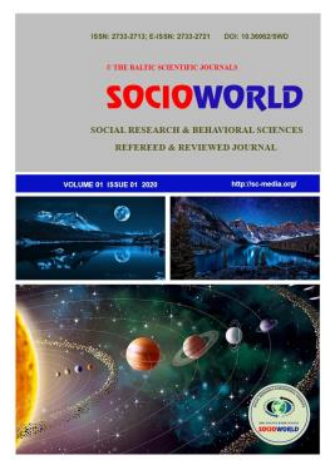


Society of Azerbaijanis living in Georgia. NGO. (Georgia, Tbilisi) is publishing scientific papers of scientists on Website and in Referred Journals with subjects which are mentioned below:

(C) Southern Caucasus Scientific Journals

ISSN: 2346-8068; E-ISSN: 2346-8181;

DOI PREFIX: 10.36962/ALISJMSC

Ambiance in Life-International Scientific Journal in Medicine of Southern Caucasus.

https://scia.website/index.php/AILISJMSC

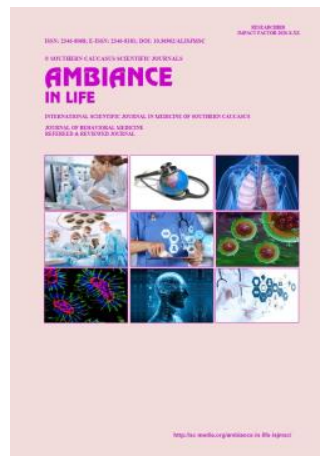

Representation of the International Diaspora Center of Azerbaijan in Georgia. NGO. (Georgia Tbilisi) is publishing scientific papers of scientists on Website and in Referred Journals with subjects which are mentioned below:

(c) Southern Caucasus Scientific Journals

ISSN: 2298-0946, E-ISSN: 1987-6114; UDC: 3/k-144

DOI PREFIX: 10.36962/CESAJSC

The Caucasus-Economic and Social Analysis Journal of Southern Caucasus https://scia.website/index.php/CESAJSC

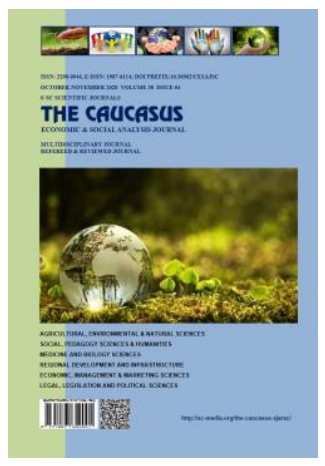




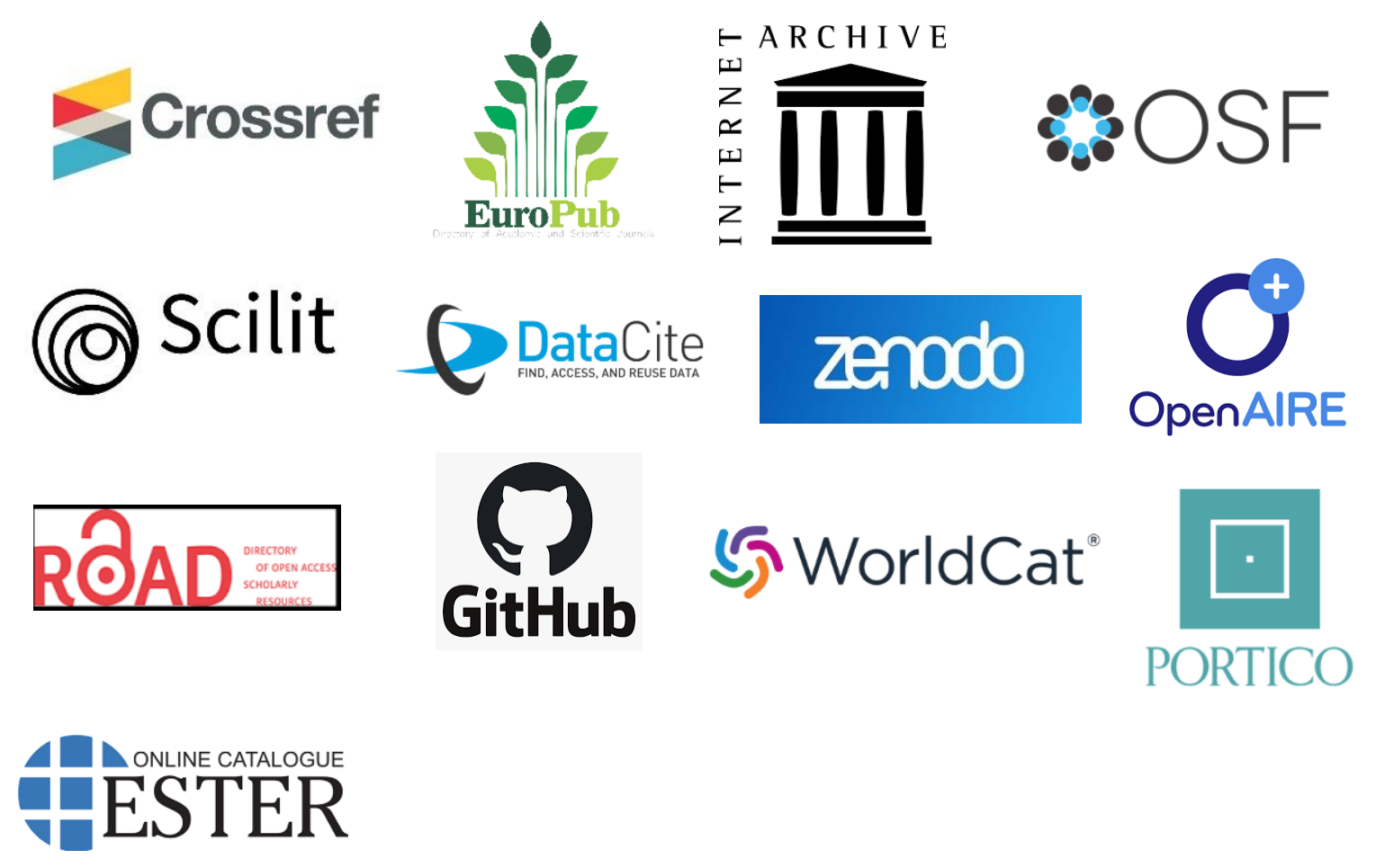

Accepted for publication in this edition / Bu nəşrdə dərc oluması üçün qəbul edilib - 04.07.2021

ISSN: 2674-4562, E-ISSN: 2674-4597, UDC: $620.9(051)(0.034)$

CPublisher: '’University of Economics.' Energy Economics Center. EEC. (Azerbaijan, Baku)

CNəşriyyat: 'İqtisad Universitet." Enerji İqtisadiyyatı Mərkəzi. EEC.

Director: Elshan Hajizade. Doctor of Economic Sciences. Professor.

Direktor: Elşən Hacızadə. İqtisad Elmləri Doktoru. Professor.

Deputy of director: Namig Isazade. PhD in Business Administration.

Direktor müavini: Namiq İsazadə. Biznesin İdarə Olunması üzrə. PhD.

Registered address: 6, Istiglaliet street, Baku, Azerbaijan, AZ 1001

Qeydiyyat ünvanı: 6, İstiqlaliyyət küç. Bakı Azərbaycan, AZ1001

CEditorial office: 6, Istiglaliet street, Baku, Azerbaijan, AZ 1001

CRedaksiya: 6, İstiqlaliyyət küç. Bakı Azərbaycan, AZ1001

CTypography: '’University of Economics.' Energy Economics Center. EEC. (Azerbaijan, Baku)

CMətbəə: '’Iqtisad Universitet.' Enerji İqtisadiyyatı Mərkəzi. EEC. (Azerbaijan, Baku)

Registered address: 6, Istiglaliet street, Baku, Azerbaijan, AZ 1001

Qeydiyyat Ünvanı: 6, İstiqlaliyyət küç. Bakı Azərbaycan, AZ1001

CPublisher: MTÜ International Center for Research, Education and Training. (Estonia, Tallinn), R/C: 80550594

CNəşriyyat: MTÜ Beynəlxalq Tədqiqat, Təhsil \& Təlim Mərkəzi. Qeydiyyat kodu: 80550594

Management Board Member: Seyfulla Isayev. Azerbaijan.

Direktor və Təsisçi: Seyfulla İsayev. Azərbaycan.

Deputy \& Founder: Namig Isazade. PhD in Business Administration.

Müavini və Təsisçi: Namig Isazade. $\mathrm{PhD}$ in Business Administration.

CEditorial office / Redaksiya: Harju maakond, Tallinn, Kesklinna linnaosa, Narva mnt 5, 10117

CTypography / Mətbəə: MTÜ International Center for Research, Education and Training. (EESTI, Tallinn),

Registered address / Qeydiyyat Ünvnı: Harju maakond, Tallinn, Kesklinna linnaosa, Narva mnt 5, 10117

Telephones / Telefonlar: +994 5524170 12; +994 518648894

Website/Veb səhifə: https://scia.website/

E-mail: sc.mediagroup2017@gmail.com 

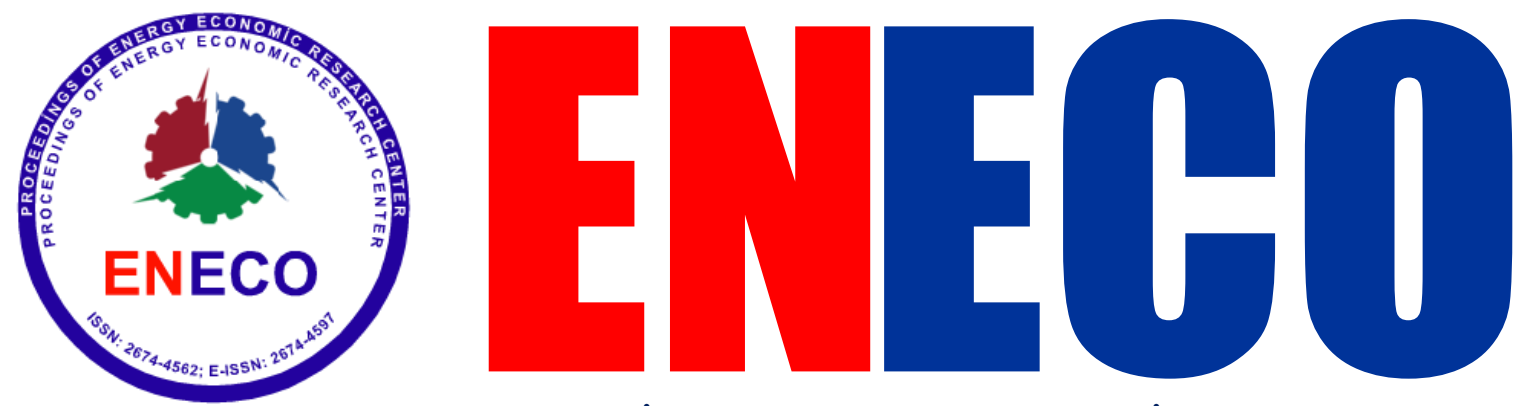

PROCEEDINGS OF ENERGY ECONOMIC RESEARCH CENTER

ENERJI İQTISADIYYATI MəRKəZINIIN XəBӘRLӘRI

VOLUME 06 ISSUE 022021

CILD 06 BURAXILIŞ 022021

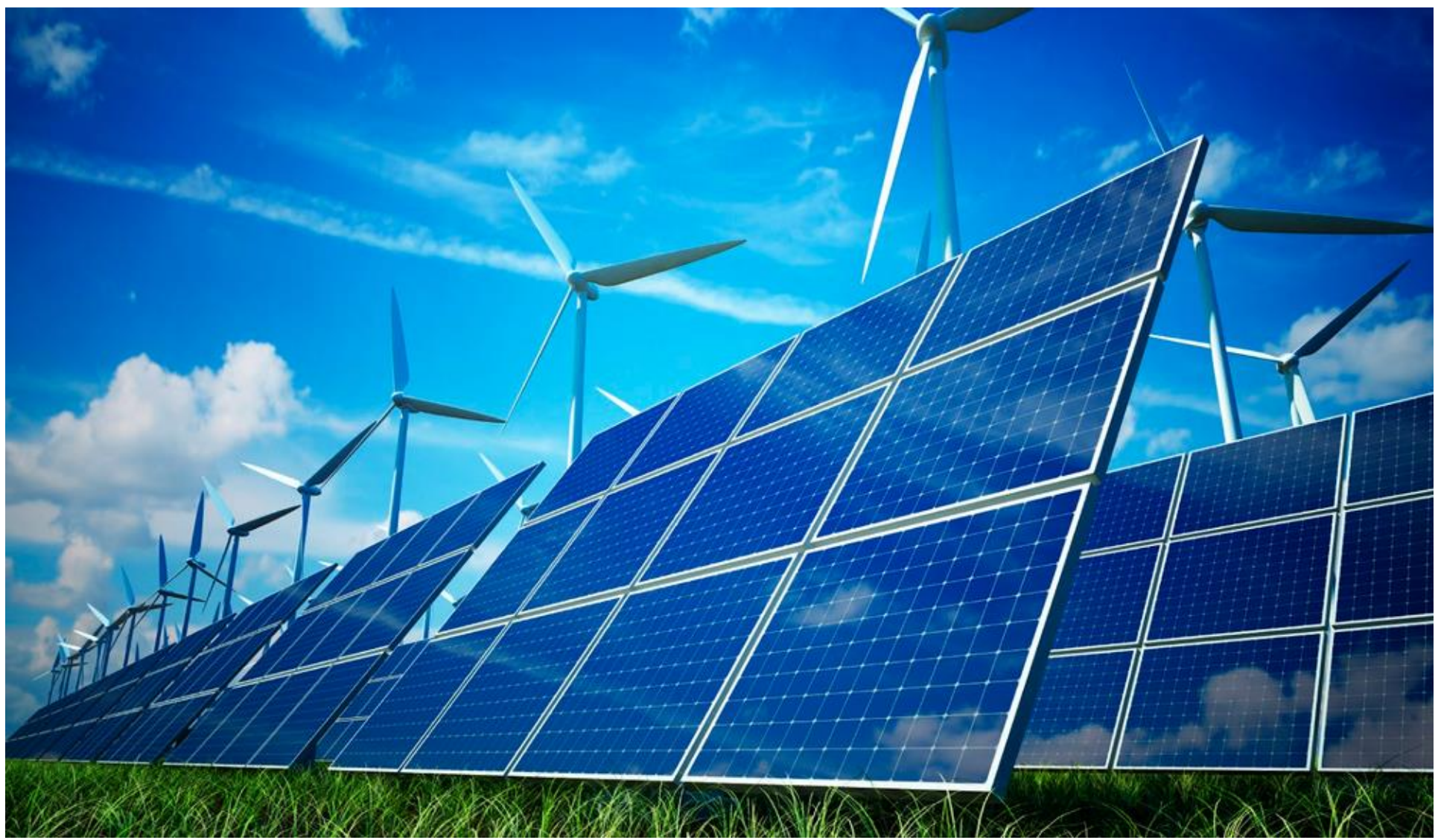

Ümumi lqqisadiyyat

Beynəlxalq İtisadiyyat

Biznes İdarəetmə və Ticarət İqtisadiyyatı, Marketinq, Mühasibat, Personal İqtisadiyyat İqtisadi İnkişaf, İnnovasiya, Texnoloji Dəyişiklik və Artım

Kənd Təsərrüfatı və Təbii Qaynaqlar İqtisadiyyatı, Әtraf Mühit və Ekoloji lqtisadiyyat

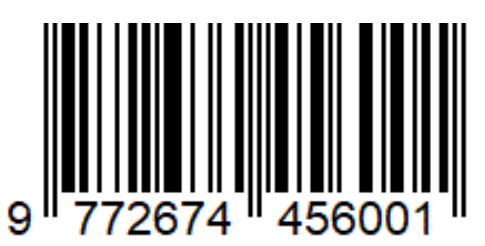

Platform \& workflow by OJS/PKP 